\title{
علاقتم معجزات الأنبياء بالتقاسم الحضاري " عصا سيدنا موسى أنموذجا "
}

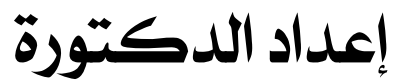 \\ ناديت عبد الهادي عبد السلام أحمد \\ مدرس العقيدة والفلسفتر \\ بكليتالدراسات الإسلاميتّوالعربيتة للبنات بالزقازيق
}



علاقة معجزات الأنبياء بالتقاسم الحضاري

( عصا سيدنا موسىى أنموذجاً )

نادية عبد الهادي عبد السلام أحمد قسم العقيدة والفلسفة ، كلية الدراسات الإسلامية والعربية للبنات بالزقازيق - جامعة

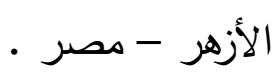

NadiaAhmed.el.8.406@azhar.edu.eg / البربد الإكتروني الإنير

الم|خص

يهدف البحث إلي بيان أن معجزات الأنبياء - عليهم السلام - لم تتتهي لأنها أفعال الله تعالي وأفعاله تعالي لا تتتهي ، وأن لمعجزات الأنبياء أثرها القائم في الحياة لإعمار الكون وإقامة الحضارات ، فقد أمرنا الله تعالي بالاقتداء بهم ليس في العقائد فقط وإنما في كل مناحي الحياة ، ومعجزة العصا لسيدنا موسى عليه السلام ، كان فيها من المعجزات الكثير ، فقد كانت منجاة لسيدنا موسى عليه السلام و بني إسرائيل ، ومهلكة لفرعون وجنوده ، وسيبين البحث كيفية الاستفادة من تلأك المعجزة في العصر الحديث ، وتوجيه أنظار الناس لما في المعجزات من أسرار وكيفية

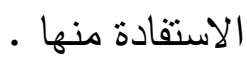
الكلمات المفتاحية علاقة - معجزات - أنبياء - نقاسم - حضاري 
علاقة معجزات الأنبياء بالتقاسم الحضاري

\section{The relationship of the miracles of the Prophets to the} (cultural sharing the stick of Moses as a model)

Nadia Abdel Hadi Abdel Salam Ahmed

Department of Belief and Philosophy, College of Islamic and Arabic Studies for Girls, Zagazig

Email / NadiaAhmed.el.8.406@azhar.edu.eg

Summary

The research aims to show that the miracles of the prophets peace be upon them - did not end because the actions of God Almighty and His deeds do not end, and that the miracles of the Prophets have their existing effect in life to build the universe and establish civilizations. God Almighty has commanded us to follow them not only in beliefs but in all aspects of life. And the miracle of the stick of our master Moses, peace be upon him, it contained many miracles, as it was a rescue for our master Moses, peace be upon him and the children of Israel, and a ruin for Pharaoh and his soldiers, and the research will show how to benefit from that miracle in the modern era, and direct people's attention to the secrets of miracles and how to benefit from them.

key words: Relationship, Miracles ,Prophets, Sharing, Civilized

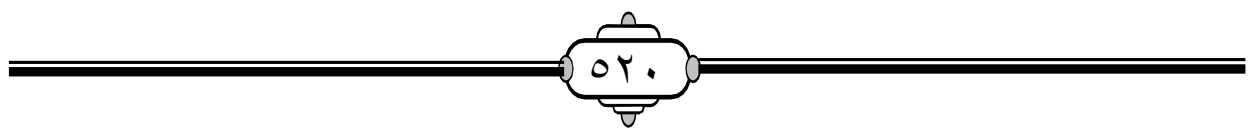




\section{علاقة معجزات الأنبياء بالتقاسم الحضاري}

\section{المقدمة}

الحمد لله الذي أرسل رسله هداية للناس وأيدهم بالمعجزات ، والصلاة والسلام على معلم البشرية سيدنا محمد وعلى آله وصحبه وسلم •

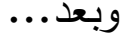

فإن القرآن الكريم معجزة خالدة ووحى إلهى ، عجز البشر عن الإتيان بمثله ،

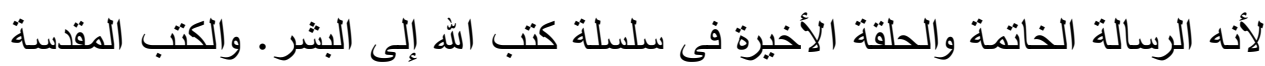
كلها كتب هداية وإرشاد فلا يجد الإنسان فيها نظريات علمية ، بل إثارات مجملة عامة الهدف منها بيان أنها موجودة وتقع بقدة الخالق عز وجل .، ولقد كّرم الله الإنسان فرفع من شأنه وأعلى قدره وجعله خليفته فى الأرض وكلّفه بعمارتها قال

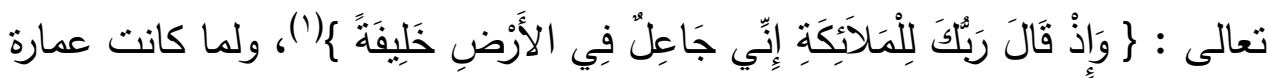
الأرض أمراً واجباً لا يتحقق إلا بتطبيق العلم ـ كان التكريم للإنسان بالعلم ، فعلّمه العه الله الأسماء كلها قبل أن يهبط الى الأرض ، حيث زوده بالعلم الذى به يستطيع أن

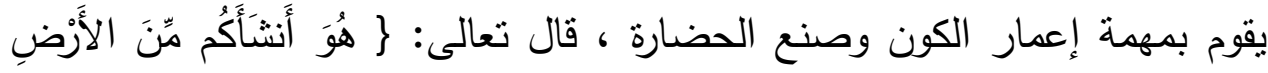

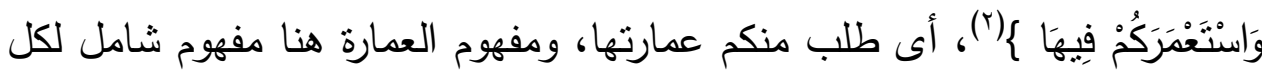
ألوان التعمير المادى والمعنوى ، وقد جاء التكليف الإلهي لسيدنا آدم - عليه السلام - بغية القيام بمهيته التى كُلف بها وهى إعمار الأرض ماديا ومعنويا ، أى صنع

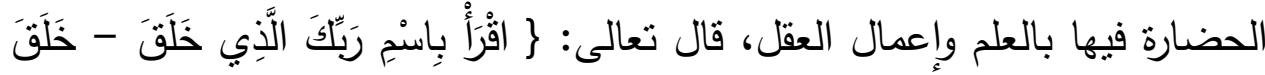

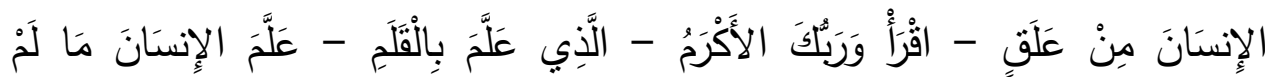

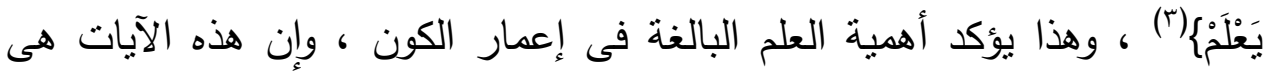
تتويج لرسالات الأنبياء عليهم السلام ممثلة فى الرسالة الخاتمة ، الأمر الذى يؤكد إلى

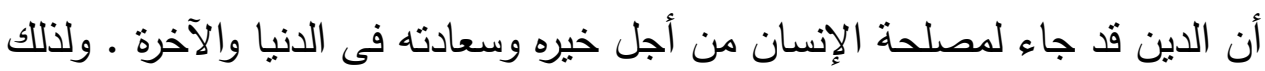




\section{علاقة معجزات الأنبياء بالتقاسم الحضاري}

فإن القرآن الكريم يأمر الإنسان بالنظر والتدبر والتفكر والعمل على تتمية هذه الملكة باستثمارها ، وإعمال العقل فى كل أمور الحياة ، فقد أمر القرآن الكريم بالنظر والتدبر فى أمرين : باله

أولهما: النظر فى كون الله وملكوته والتفكر فيه وفى سيره ونظامه ،لأن العقل إذا تدبر ذلك أداه التدبر إلى الإقرار بوجود خالق قدير قال تعالى ( قُلِ انْظُرُوا مَاذًَا فِي

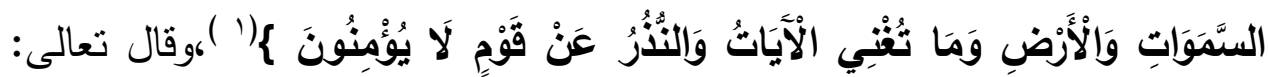

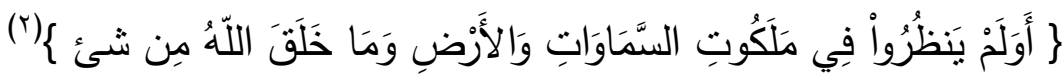
فهذا أمر من اله للإنسان بالتدبر فى هذا الكون المشهود بكل ما فيه "و هذا يدل على مطلوبين الأول أنه لا سبيل إلى معرفة الله تعالى إلا بالتدبر في الدلائل كما

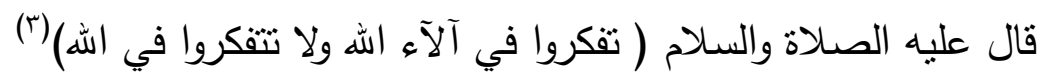
والثاني وهو أن الدلائل إما أن تكون من عالم السماوات، أو من عالم الأرض، أما الدلائل السماوية فهي حركة الأفلاك ومقاديرها، وما فيها من الثمس والقمر من الثر والكواكب وما يختص به كل واحد منها من المنافع والفوائد وأما الدلائل الأرضية فهي النظر في أحوال العناصر الأرضية وفي أحوال المعادن والنبات وأحوال الإنسان خاصة (أ)

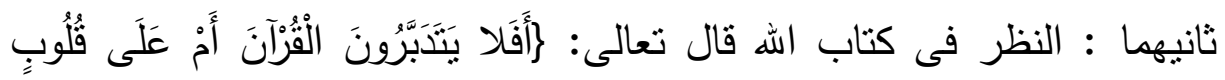

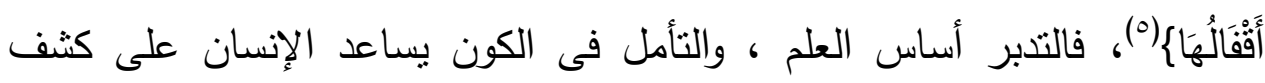

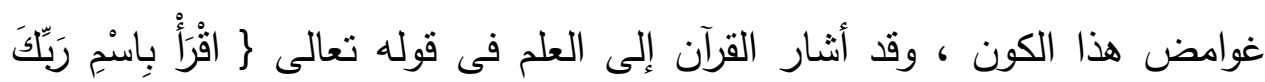

$$
\begin{aligned}
& \text { (1) سورة يونس ، آية 1 ـ 1 . }
\end{aligned}
$$

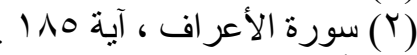

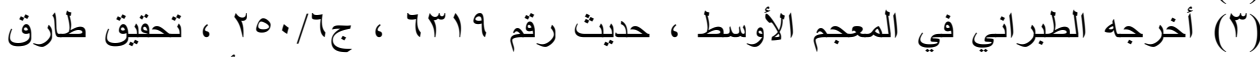

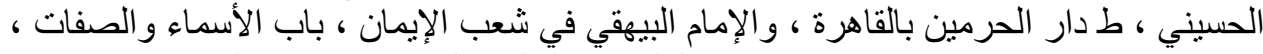

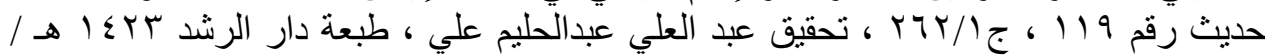

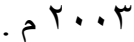

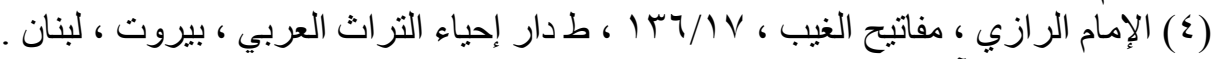

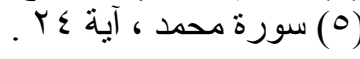
विद 
الَّذِي خَلَقَ)|(')، فتقديم الأمر بقراءة الكون المنظور إنما هى دعوة إلى الإنسان للتأمل

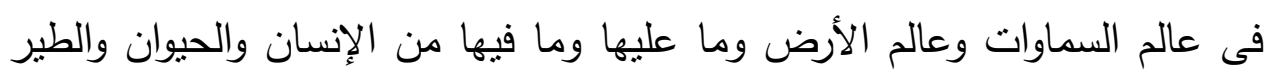
وعالم البحار والمحيطات والنباتات، وفى جوف الأرض من كنوز ومعادن • وتبدو هذه دعوة واضحة إلى إعمال العقل، فلا علم بلا عقل أو فكر ، وهذا يعطى للإنسان

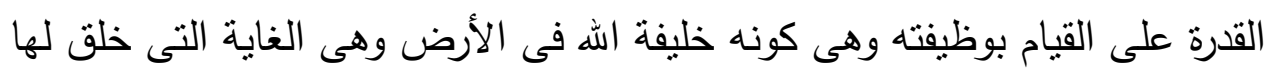
ويسعى لتحقيقها منذ خلق آدم - عليه السلام - وحتى قيام الساعة. ثم إن العقل هو الصفة التى مُيز بها الإنسان واختص بها عن سائر

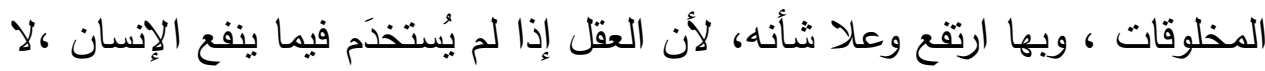

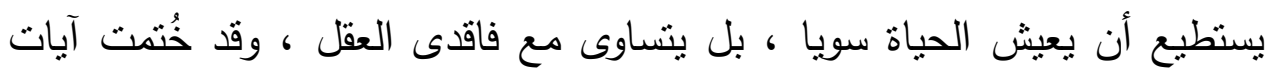
كثيرة فى القرآن الكريم بقوله ( تتفكرون ، تعقلون ، يفقهون ) للحث على التفكير .، وقد عاب القرآن الكريم على المشركين إغفالهم عقولهم وتقلبدهم السابقين فى الثرك

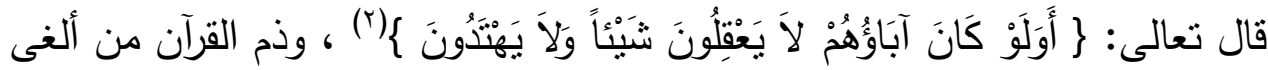

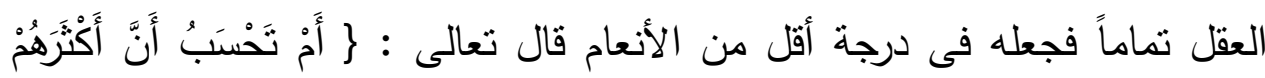

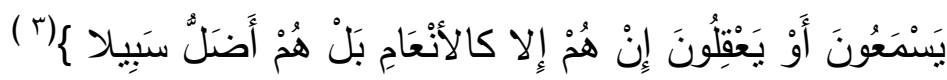
وقد أوضح الإمام محمد عبده العلاقة بين العلم والعقل فقال : "إن العلم مسرح إلإل نظر العقل ، والعقل قوة من أفضل القوى الإنسانية ، بل هي أفضلها علي الحقيقة ، وقد وضع لها العليم الحكيم لذة ، كما وضع لكل قوة سواها نعيما و لذة ...... وكلما

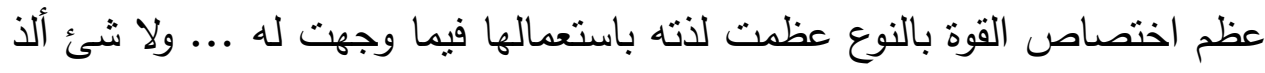

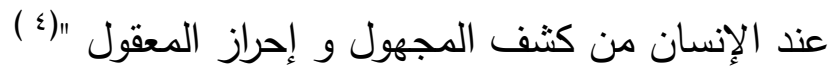

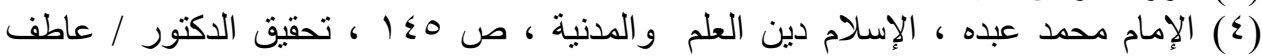

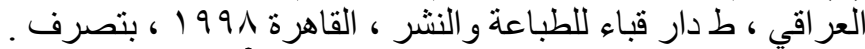


أجل حض القرآن الكريم على العلم ورغّب فيه ورفع من شأنه ، وأمر المسلمين بالتفكر فى الكون ، فيهتم العلم بدراسة الظواهر الطبيعية المختلفة عن طريق

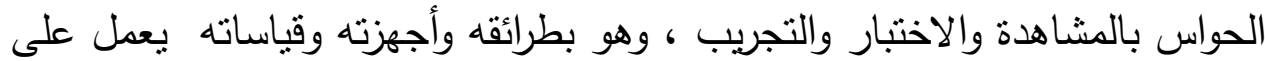

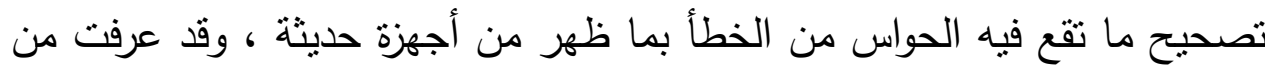

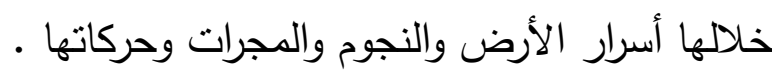
كما بث القرآن الكريم كثيرا من الإثارات العلمية فنهض المسلمون الأوائل الذين

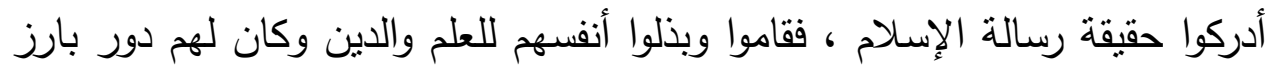

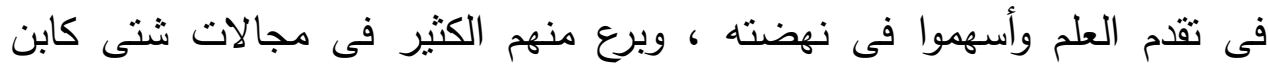

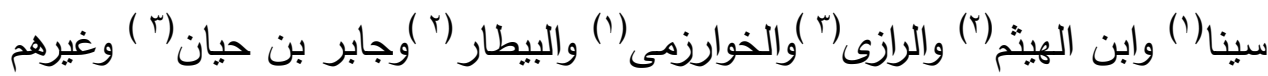
وغيرهم ممن لهم دور فى بناء صرح العلم والحضارة.

(1) ابن سينا : الحسين بن عبد الله بن الحسن بن علي بن سينا البلخي، ثم البخاري، ويلقب بالثيخ

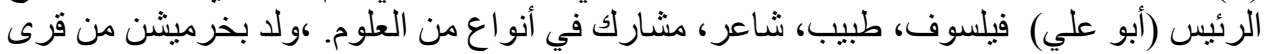

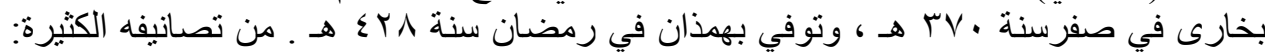

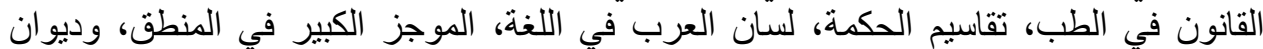

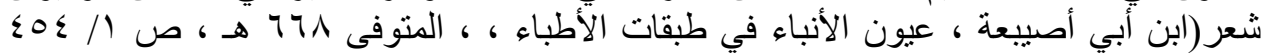

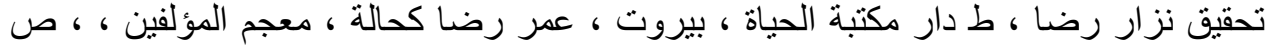

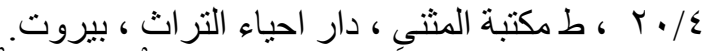

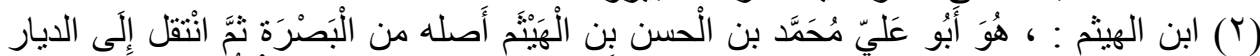

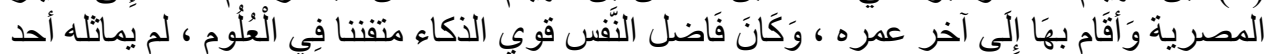

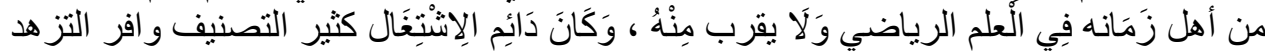

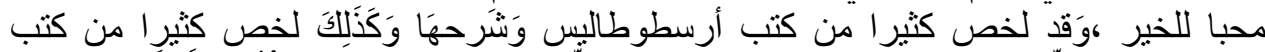

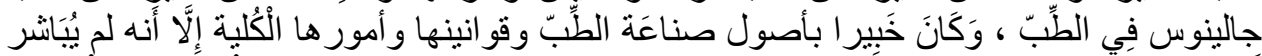

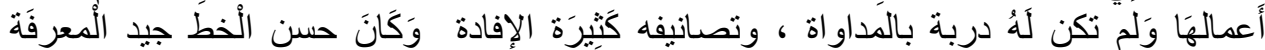

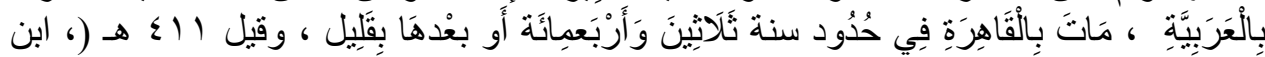

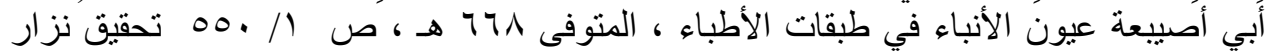

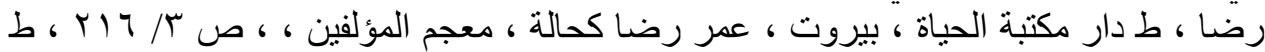

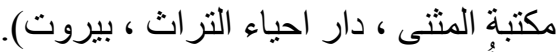

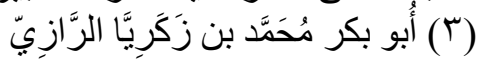

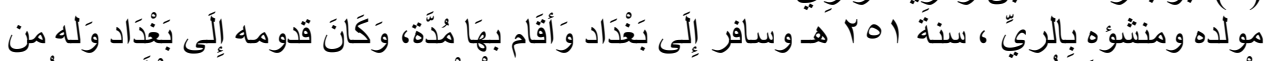

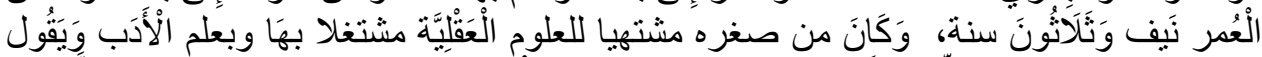

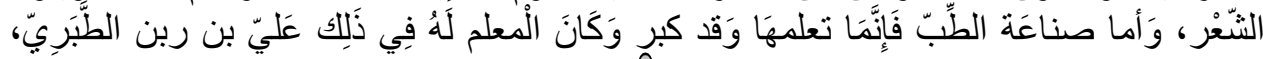




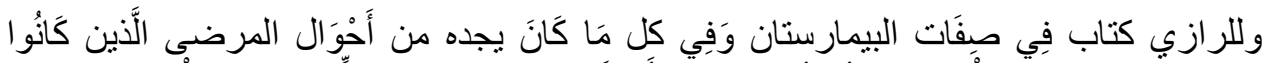

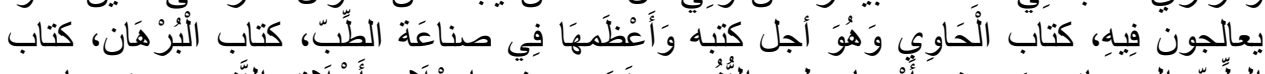

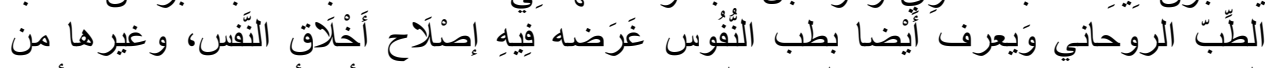

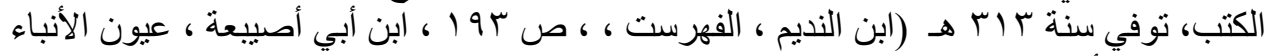

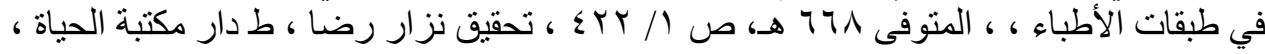

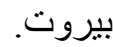

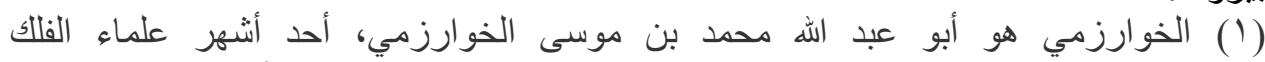

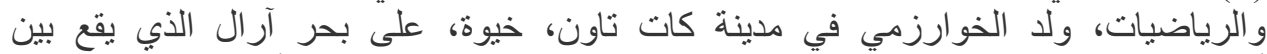

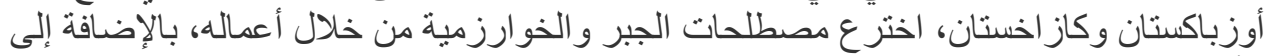

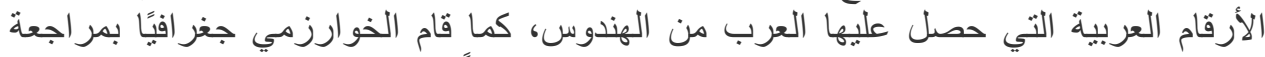

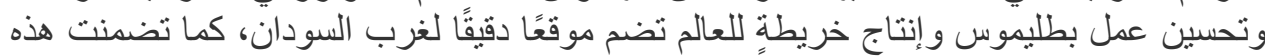

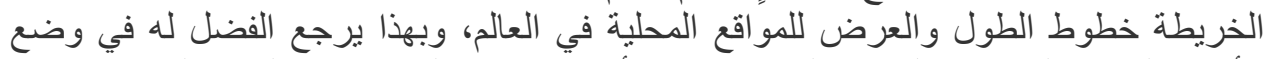

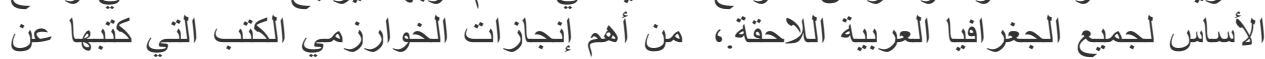

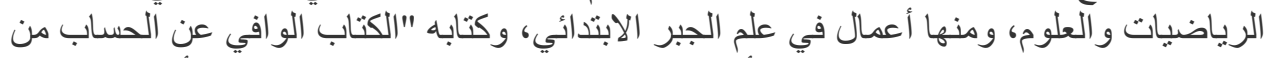

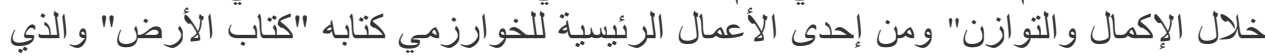

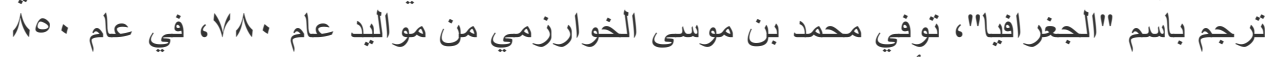

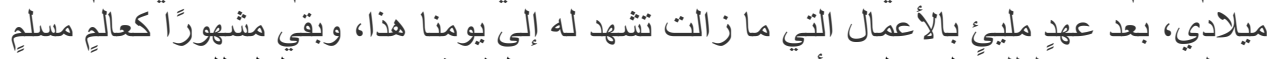

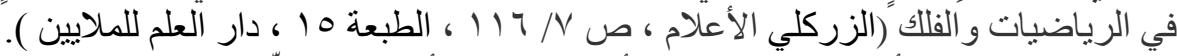

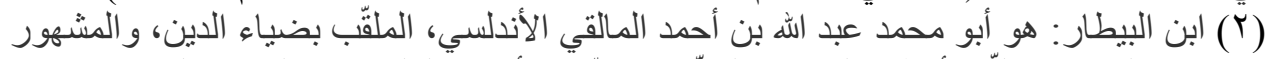

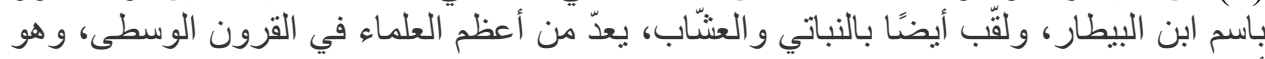

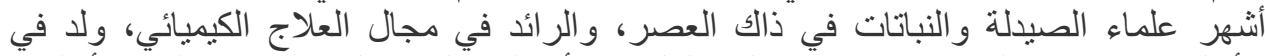

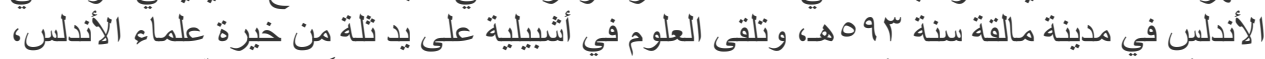

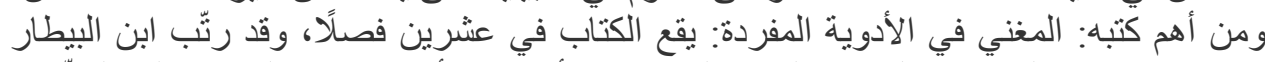

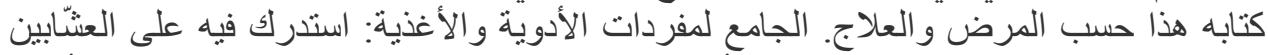

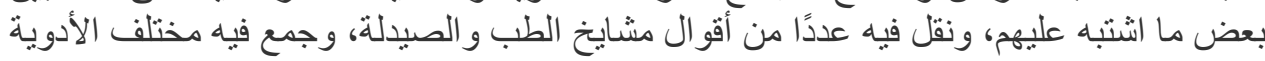

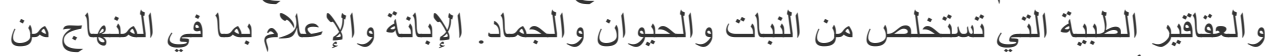

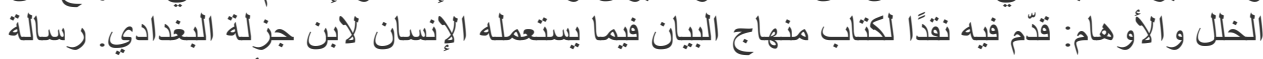

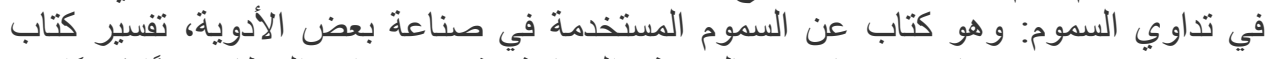

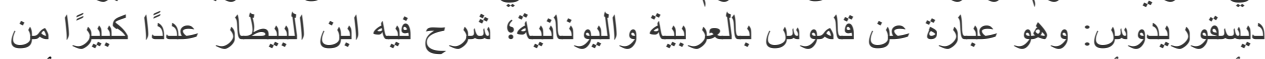

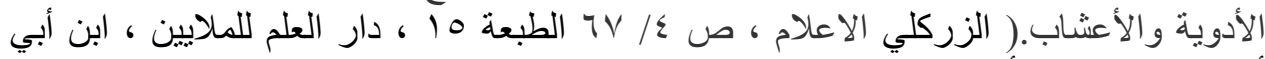

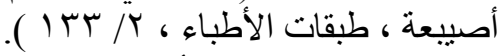

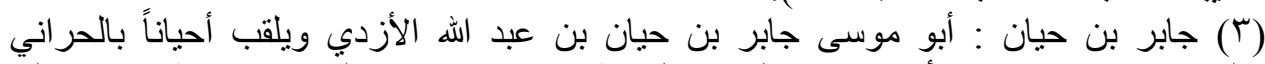

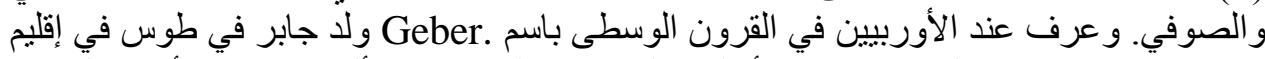

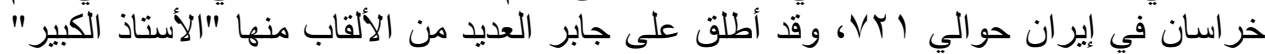

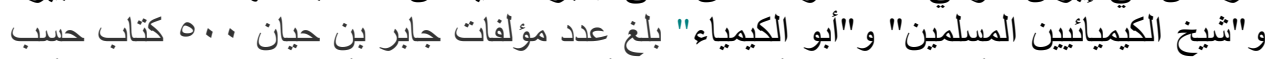

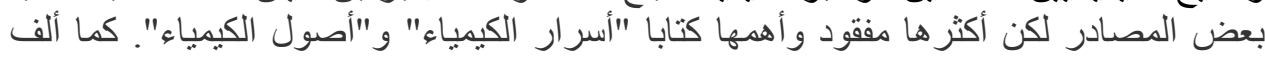

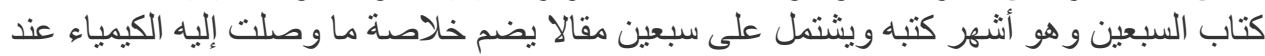

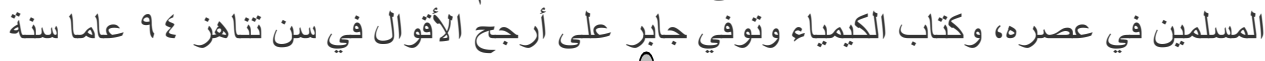




\section{علاقة معجزات الأنبياء بالتقاسم الحضاري}

لكن البيّن أنه عندما أهمل هذا المنهج القرآنى وهو منهج الرصد والقياس(') لما فى الكون ، تأخر العالم العربى والإسلامى وظهرت الخرافات والأوهام والنظر إلى الى أمجاد الماضى كأنها بعيدة لا يستطيعها البشر . لقد أخبر القرآن الكريم عن السماء والأرض ، وكثيرا ما نبّه على استخدام منهج الرصد والتتبع لما فى الكون من ظواهر ونظام عام وشامل، قال تعالى ـ سَنُرِهٍِْ

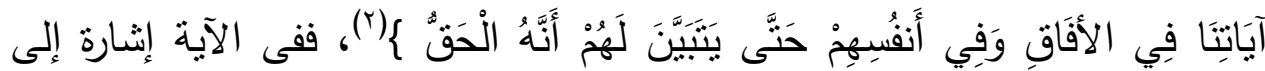
تتبيه الإنسان بالتفكر فى الآفاق وفى الأنفس وبهذا المنهج اكتثف العلم الجديد من النظريات والأجهزة لمعرفة المزيد من علم الفلك و الجيولوجيا و البحار و النبات و الحيوان و علم النفس وتركيب جسم الإنسان ، وما عرف الإنسان كل هذا إلا بالنظر فى الكون واختراع الأجهزة اللازمة لذلك فاكتشف الجديد ، و بيان قدرة الخالق فى الرى

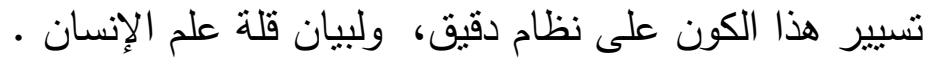
وحين أرسل اله الرسل عليهم السلام لتعربف البشر طرائق توحيده ، وترك عبادة ما سواه ، وهدايتهم ،وتعليمهم الصناعات ، وقد شاءت إرادة الله تعالي أن يكون تعليم الناس الصناعات عن طريق بعض المعجزات ، فالمعجزة آية صدق من الله تعالي للرسل عليهح السلام ، ولتكون من باب إعمار الأرض وإقامة الحضارة ، فهم القدوة الذين أمرنا الله تعالي باتباعهم ماديا ومعنويا .

10

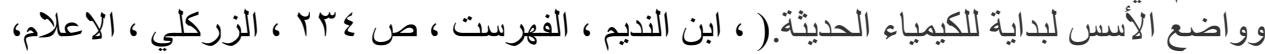

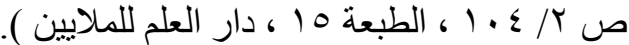

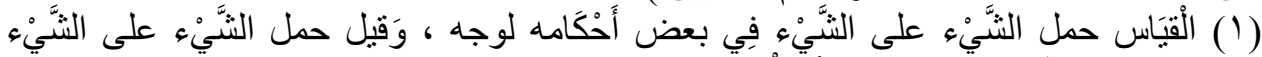

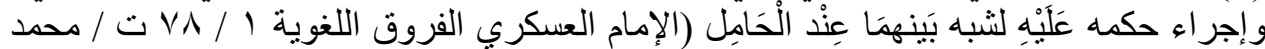

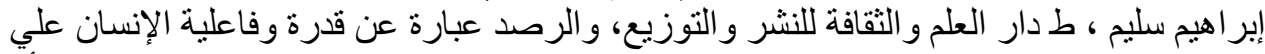

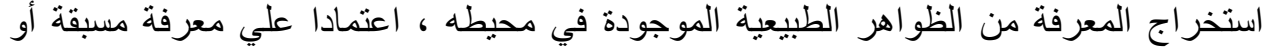


فبالنظر في معجزات الأنبياء عليهم السلام وتأملها وجدناها تحمل إثنارات لعمارة الأرض فها هم الأنبياء - عليهم السلام - يعملون في مهن تعلمها الناس النهاء بعد ذلك كان لها دورها في إعمار الأرض وقيام الحضارة ، منها حياكة الملابس التي كان يعمل بها سيدنا إدريس عليه السلام حتى قيل :إنه كان يحيك في اليوم الواحد مائة ثوب ، فأخذ الناس منه صناعة الملابس وقامت المصانع بتلك المهنة وأصبحت مصدر دخل لكثير من الناس ،واتخذت من الزراعة موادها ، وقامت

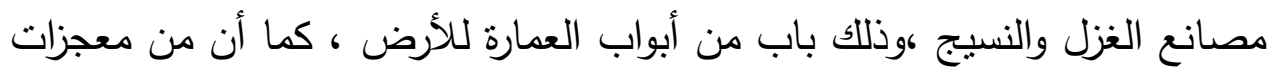
سيدنا عيسى عليه السلام إحياء الموتى ،وإبراء الأكمه والأبرص بإذن الله ، ومنه

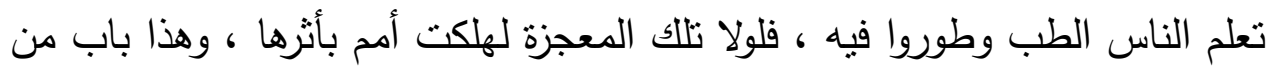
أبواب الإعمار وغيرها الكثير من المعجزات ، وسوف نتتاول في بحثنا هذا إحدى معجزات سيدنا موسي عليه السلام لنرى دورها في إعمار الأرض والتكامل والتقاسم الحضاري ، وهي معجزة العصا .

$$
\text { أسباب اختيار الموضوع }
$$

هنالك عدة اسباب دعتني لاختيار هذا الموضوع منها : ا- أن المعجزات إنما هي أفعال الله تعالي ، وهي لا تتتهي بانتهاء دور النبي عليه السلام ץ- ندرة المعالجات بمعنى أن المعجزات لم تتل حظها من الدراسة التوظيفية ،في كيفية الاستفادة من معجزات الأنبياء في عمارة الكون وإقامة الحضارات . r- بيان دور المعجزات الإلهية في التقدم العلمي والتقني والحضاري •

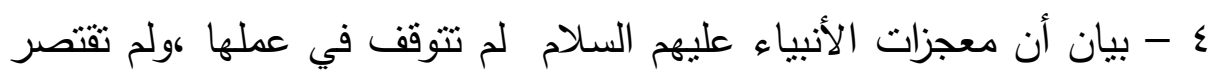

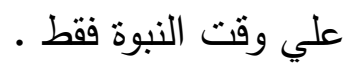

ه - بيان أن الأنبياء عليهم السلام قدوة في العقائد والتكاليف وإصلاح الكون . منهج البحث

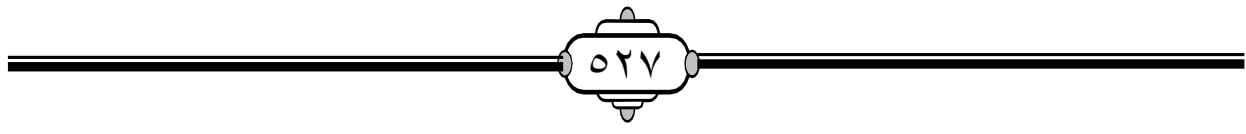


استخدمت المنهج التكاملي في البحث حسب ما تقتضيه كل جزئية من جزئياته، ويشمل المناهج الأخرى كالمنهج التحليلي ، والمنهج الاستقرائي ، والمنهج التاريخي، والمنهج الاستخلالي .حيث إن معجزة سيدنا محمد صلى الله عليه وسلم (القرآن الكريم ) عالمية وعامة وشاملة وصالحة لكل زمان ومكان ،ونحن نأخذ منه ، كما أن الن

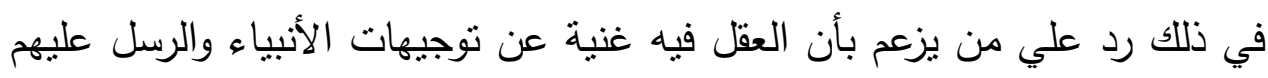
- الصلاة والسلام

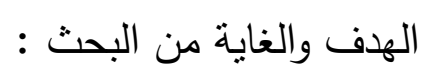

أن الهدف هو ما يضعه المرء أمامه ، وهدفي من البحث بيان أن معجزات

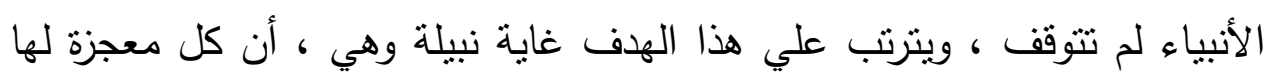
دور في النكامل الحضاري ،وفي تقدم البشرية ، كذلك إيراز دور المعجزة في الحث علي العمل اقتداء بالأنبياء عليهم السلام . خطة البحث: : - : يتكون البحث من مقدمة ،و ثنالثة فصول ، وخاتمة ، ثم المراجع والمصادر والقهرس العام

المقدمة وتشتمل علي أهمية الموضوع ، وأسباب اختيار الموضوع ، المنهج

المستخدم ، الهدف والغاية من البحث . الفصل الأول :- تحديد المفاهيم

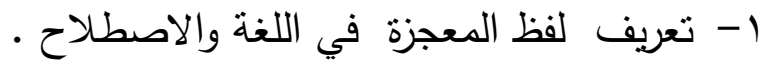
r- تعريف لفظ النبي في اللغة والاصطلاح . r- تعريف لفظ التقاسم الحضاري في اللغة والاصطلاح . ع - تعقيب ثم شروط المعجزة .

الفصل الثاني :- دور المعجزة في إثبات النبوة بوجه عام ـ(دلائل النبوة ) أولا :- هل وقع بها التحدي ؟

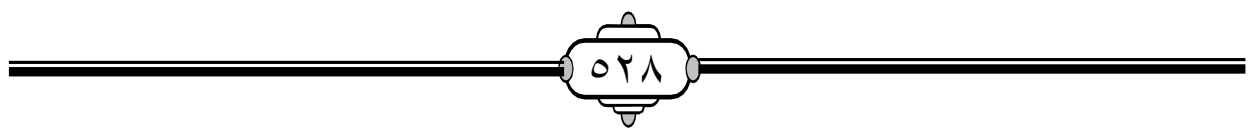




$$
\text { ثانيا :- - هل وقع لها التحدي ؟ }
$$

الفصل الثالث :- الجانب التطبيقي .

العصا في زمن سيدنا موسى عليه السلام وفيها مراحل :

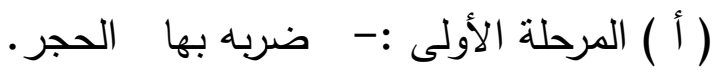

(ب) المرحلة الثانية : :- ضربه بها في البحر

(ج) المرحلة الثالثة :- بعد زمن سيدنا موسى.

ثم تأتي الخاتمة ونتنتمل علي أهم النتائج والتوصيات ، ثم ثبت بالمصادر ، ثم بـ

الفهرس العام

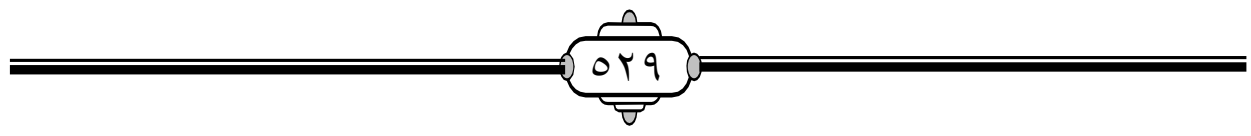




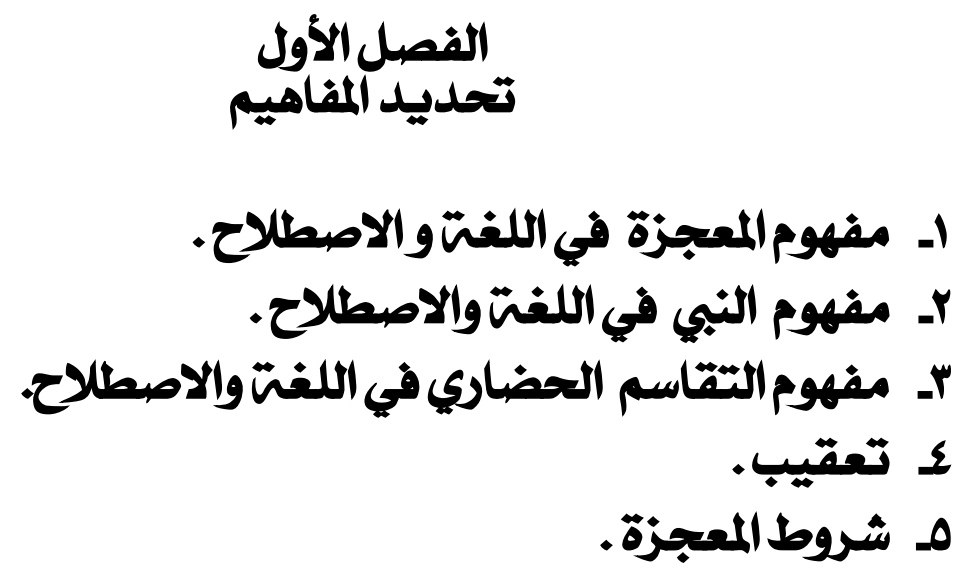




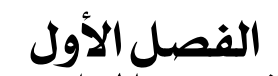 \\ تحديد المفاهيم الاول}

\section{أولا :-تعريف لفظ المعجزة}

وردت مادة الكلمة ( ع، ج. ز) في القرآن الكريم حوالي ست وعشرين مرة

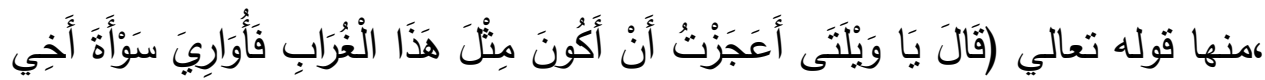

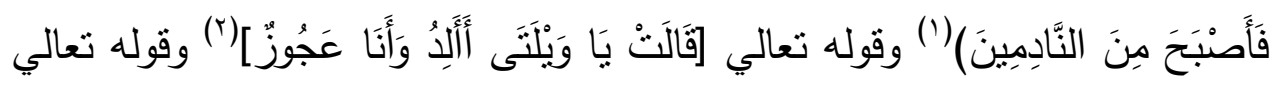

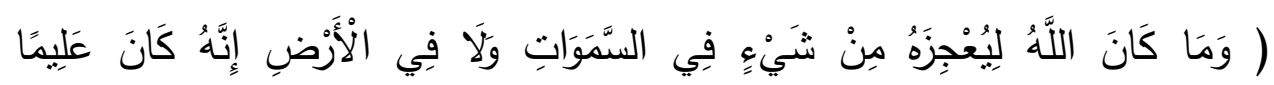

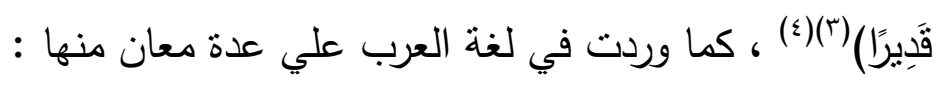

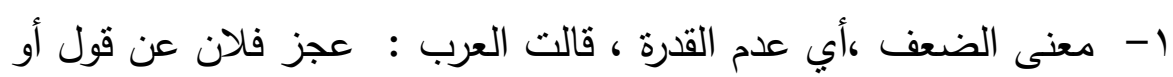
فعل معين ،إذا حاوله ولم يستطعه ،لاعتقاده عدم استطاعته له ، ولذلك أطلق على هلى المرأة المسنة الهرمة لفظ:(عجوز) لعجزها وضعفها عن الحمل والإنجاب وعن كثير من الأعمال التي كانت تقوم بها في شبابها r) بمعنى القصور، قالت العرب : عجز عن الأمر :إذا قصر عنه ،وأعجزه الثيء إذا لم يتمكن من مجاراته ، وهي اسم فاعل من الإعجاز وهي مفرد

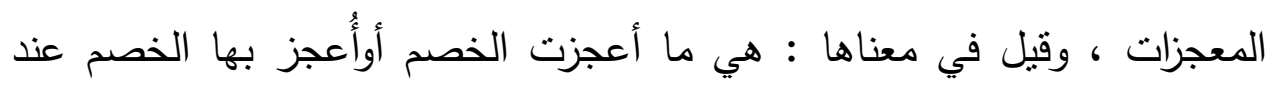
التحدي ، والهاء للمبالغة ، وسميت بذلك لعجز الناس وقصورهم عن الإتيان بمنلها

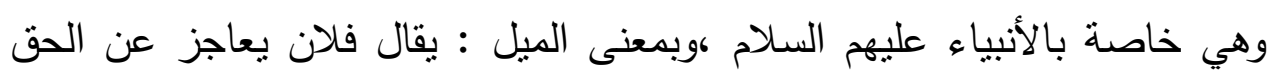
إلى الباطل أي يميل إلبه ويلتجيء بالاءئ (0)

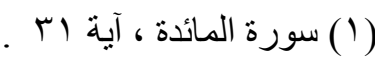

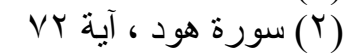

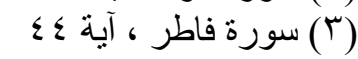

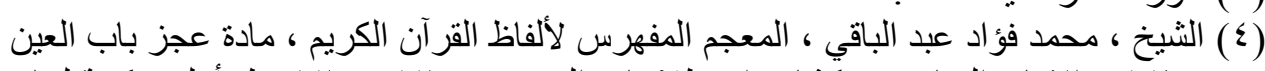

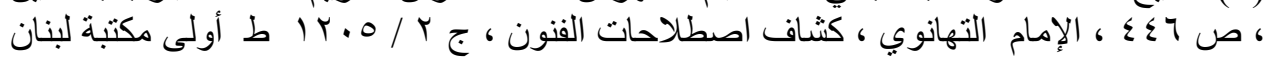

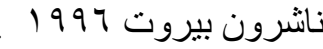

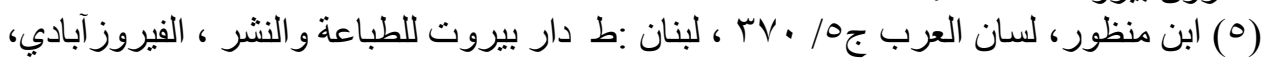

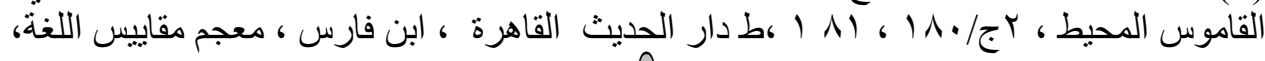


وقد وردت لفظة المعجزة في القرآن الكريم بمعنى الآية في حوالي أربع وثمانين

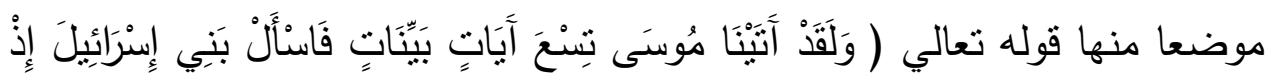

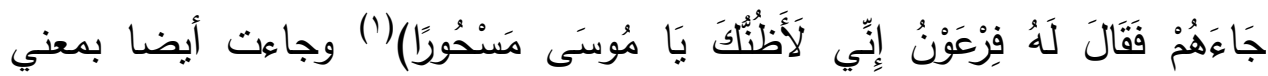

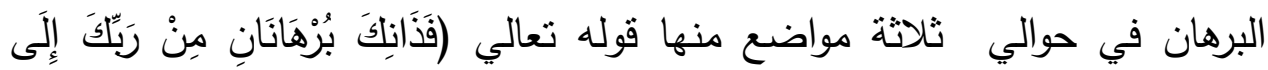

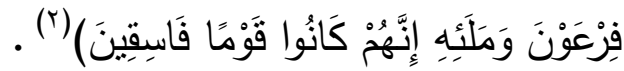

أخلص من ذللك إلي أن المعجزة علي كثرة المعاني التي وردت فيها ، تدور حول معنى عدم القدرة علي فعل الثيء مع التمكن منه وهذا هو المعنى المقصود

\section{ب) في الاصطلاح :}

تعددت تعريفات المعجزة لاى مفكري المسلمين ومنها:-

1- ظهور أمر بخلاف العادة في دار التكليف لإظهار صدق ذي نبوة من الأنبياء (r) (1)

ץ- كل ما قصد به إظهار صدق التحدي بالنبوة لمدعي الرسالة(๕). r- المعجزات هي :- أفعال الله تعالي الخارقة للعادة المطابقة لدعوى الأنبياء عليهم السلام وتحديهم للأكم بالإتيان بمثل ذلك (ه).

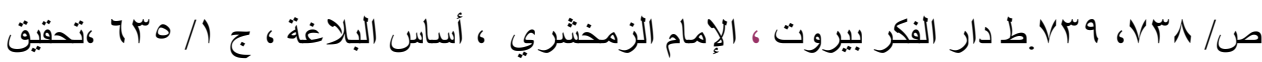

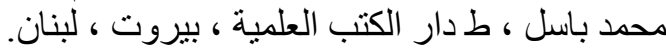

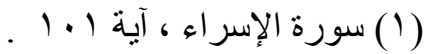



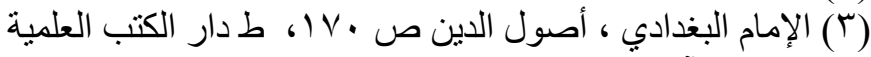

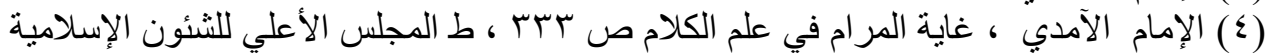

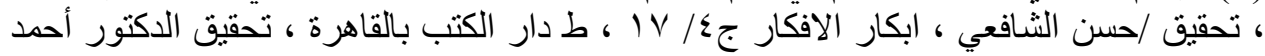

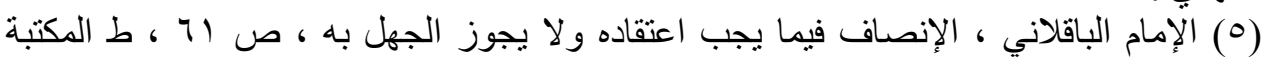

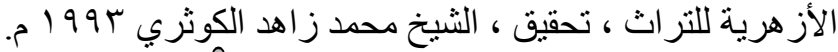


ع- هي أمر خارق للعادة مقرون بالتحدي مع عدم المعارضة(') وهذا هو أثنر

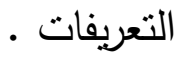

0 - هي الفعل الذي يدل علي صدق المدعي للنبوة(؟)

7 - هي أمر يعجز البشر متفرقين ومجتمعين عن الإتيان بمثلكه ، أوهي أمر إز

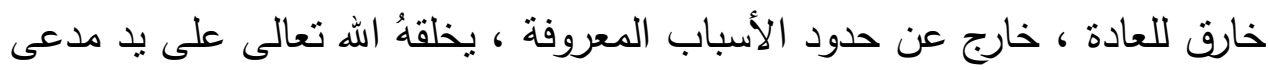

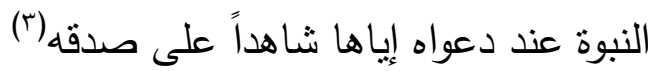

تعقيب

يتضح لنا من خلا التعريفات السابقة للمعجزة أن هنالك فروقا بين تلك

التعريفات ، منها :

أن البعض عرفها بأنها أمر خارق للعادة وهي جنس في التعريف يثمل الفعل

والقول والترك وهو الأفضل ، لأن معجزات الأنبياء تعددت وتتوعت في هذه الأمور،

فالفعل كقلب العصا حية لسيدنا موسى عليه السلام ،وإبراء الأكمه والأبرص لعيسى كاء عليه السلام ،والقول كالقرآن الكريم لسيدنا محمد عليه الصلاة والسلام ،والترك كترك النار للإحراق لسيدنا إبراهيم عليه السلام ، وهناك من قال بأن المعجزة هي فعل أو قائم مقام الفعل ،وهو تعريف قاصر لأنه قصر المعجزة علي الفعل فقط ،والمعجزة متتوعة متعددة ، ما بين المعجزات الحسية والمعنوية ، والقول والفعل والترك ، كما أن بعض التعريفات اثترطت التحدي ، والبعض لم يشترط ، لأن البعض فال لابد من التصريح بالتحدي ، والبعض لم يشترط التصريح به ـ .

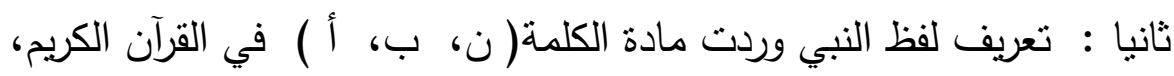

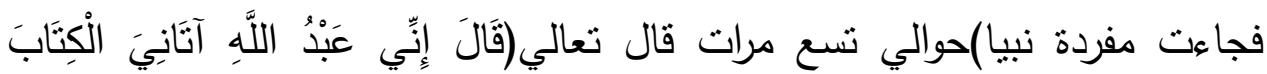

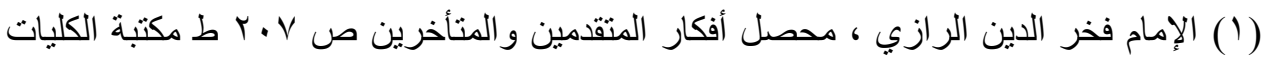

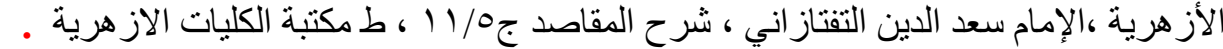

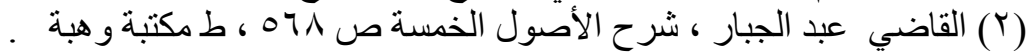

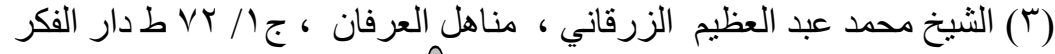




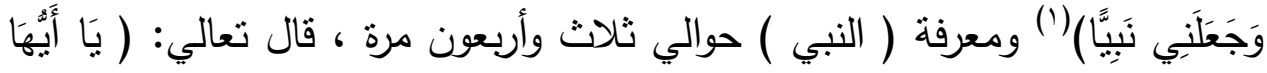

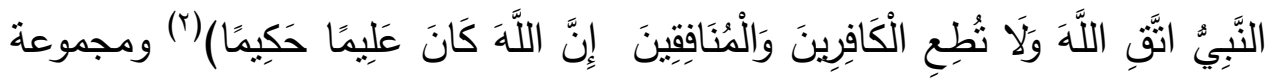

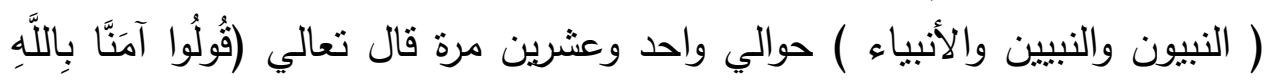

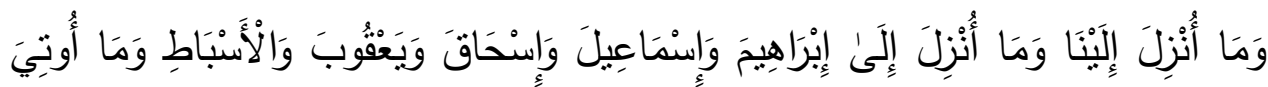

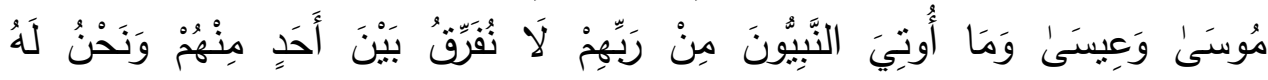

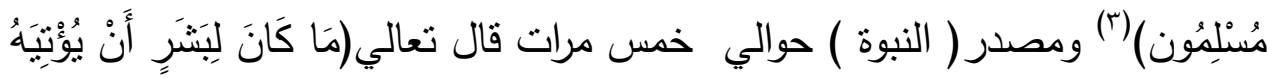

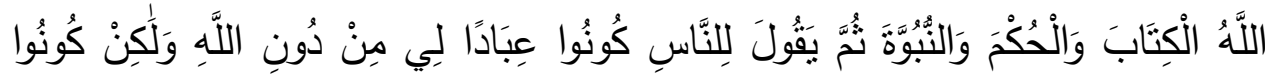

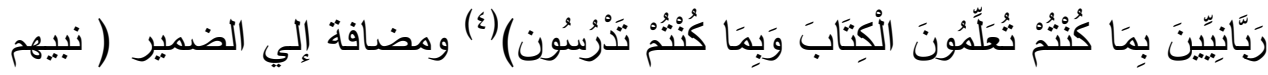

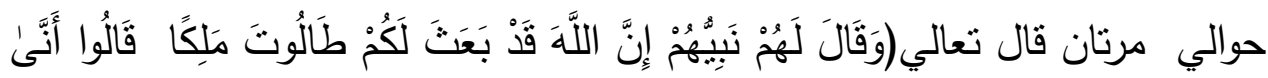

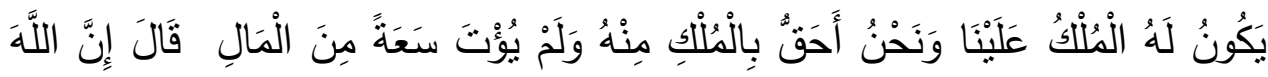

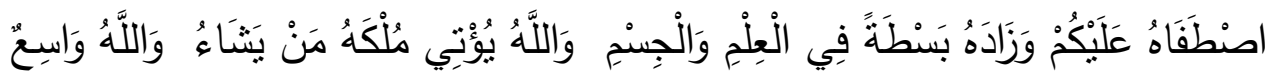

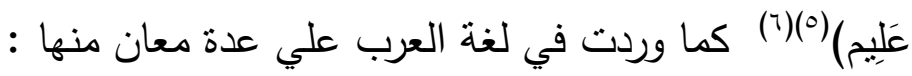
1- الإخبار ، وهي مأخوذة من النبأ بالهمزة ، قالت العرب: النبأ، الخبر يُقال:

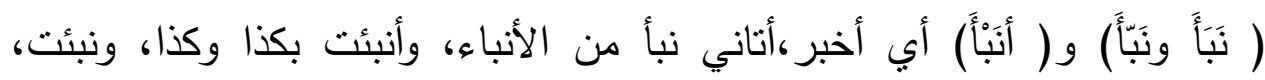

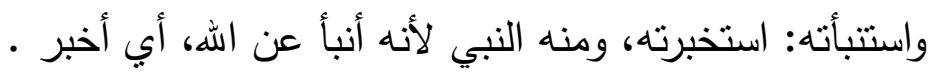
r- من النبوةة ، بمعنى المخبر فهو منبأ ومخبر عن الله تعالي .

$$
\begin{aligned}
& \text { (1) سورة مريم ، آية • بَ. }
\end{aligned}
$$

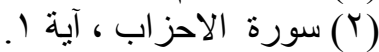

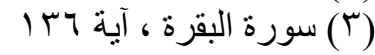

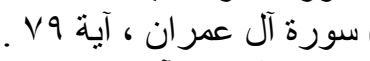

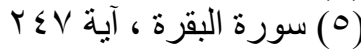

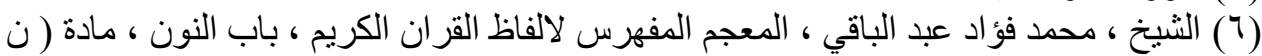

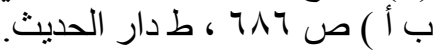




\section{علاقة معززات الأنبياء بالتقاسم الحضاري}

r - الارتفاع والعلو ، وهي من النبوة و النباوة بدون الههزة ،أبي ما ارتفع من

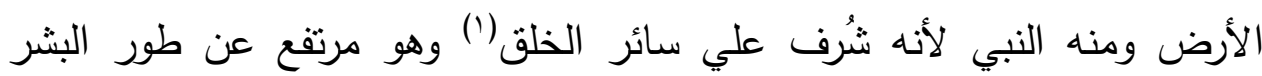

لاختصاصه بالوحي وخطاب الله تعالي له ، فهو رفيع المنزلة عند الله تعالي كل هذه المعاني مقصودة ومرادة لأن النبي جاء بخبر من عند الله تعالي الذي أرسله وبالتالي فهو مخبر عن الله تعالي ، ولا يتم ذللك إلا لمن علت منزلته عند الله ت تعالي وعند الناس - ماس

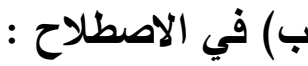

تعددت تعريفات النبي عند مفكري المسلمين منها :

1- النبوة : موهبة من الله تعالى و نعمة منه على عبده، و حاصلها يرجع إلى قول الله عز وجلّ لمن اصطفاه من عباده. أرسلتكا، و بعثنّك فبلغ عنّى،وقيل من قال له الله أرسلتك أو بلغهم عني ونحوه من الألفاظ (r) .

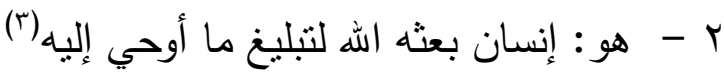

r- هو :- إنسان ذكر حر أوحى الله إليه بشرع ، ولم يؤمر بالتبليغ إٔ) . ع- أن لفظ النبي لا تستعمل في كل رفيع من الصالحين من المؤمنين ، وإنما هي مستعملة فقط فيمن يختص بمنل رفعة الأنبياء -عليهم السلام - ولا يعقل عند الظاهر منها إلا ذللك ، فالواجب فيها أن تكون منقولة من عمومها إلي هذاء الاختصاص(ه) يتبين لنا من هذه التعريفات اختلاف المفكرين في هل النبي مأمور

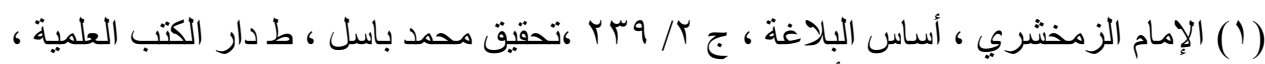

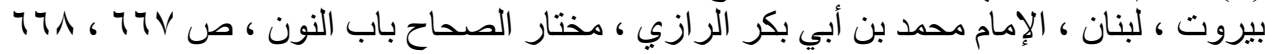

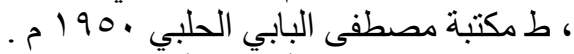

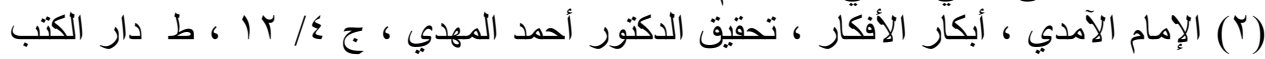

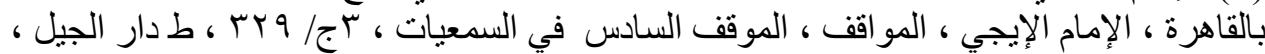

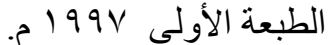
(r) الإمام سعد الدين التفتاز اني ،شرح المقاصد 9؟ نعليق د عو اد سالم ود عرفه النادي ، المقصد

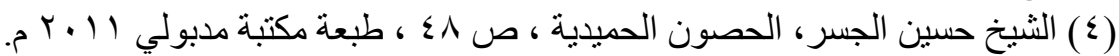

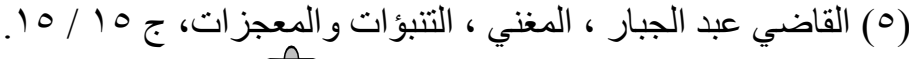


بالثبليغ أم غير مأمور ؟ فالبعض جعل النبي والرسول سواء وهم المعتزلة ، والبعض

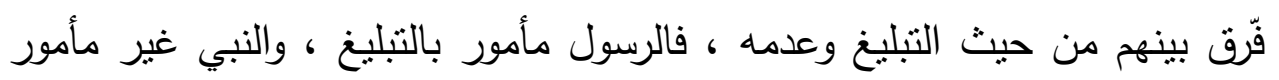

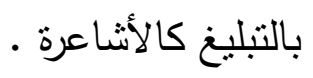

\section{ثالثا : تعريف لفظ التقاسم :}

وردت مادة الكلمة ( ق ، س، م ) في القرآن الكريم حوالي ثلاث وثلاثتون

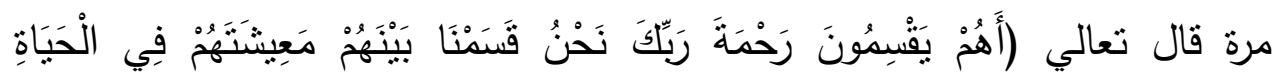

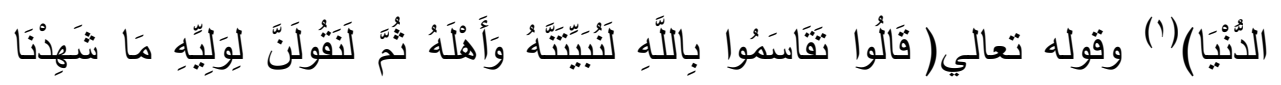

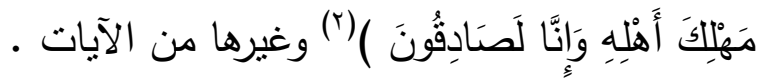
كما وردت في لغة العرب علي عدة معان منها :-

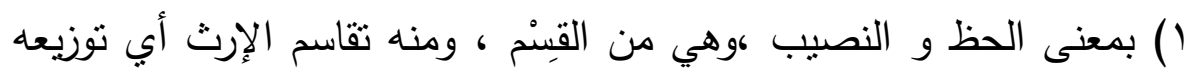
وتقسيمه وأخذ النصيب،وقاسم فلان فلانًا: أخذ كل منهما قسمه ،والتجزئة ومنه قسّّ التح الثيء : جزاه أو جعله نصفين، قسموا المال بينهم قسماً وقسموه تقسيماً واقتسموه

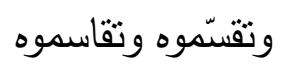

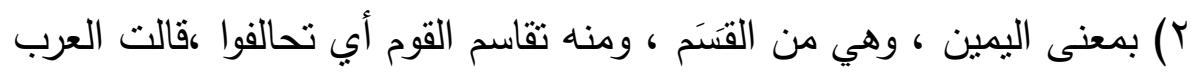

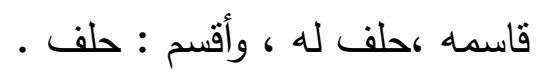
r) بمعنى المشاركة ، قالت العرب قاسمه المال وتقاسماهو و اقتسماه بينهم،

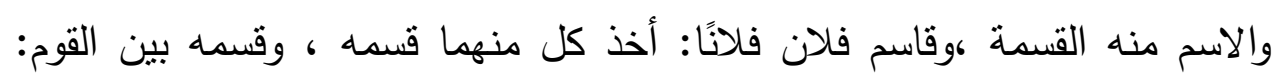

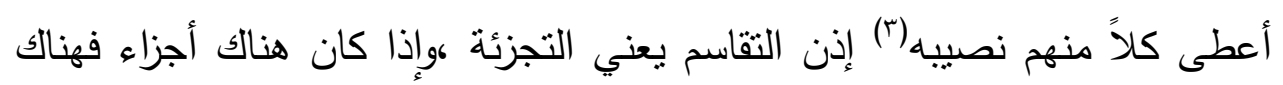

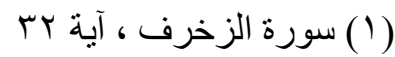

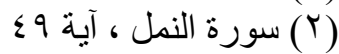

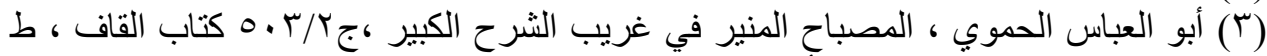

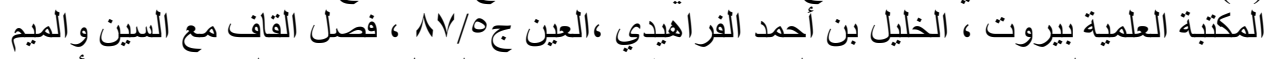

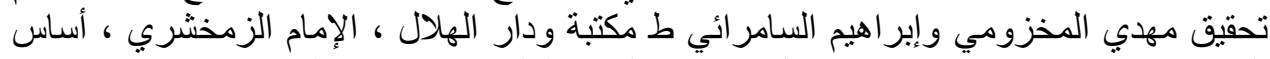

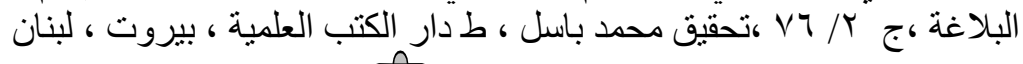


أنصبة ، وإذا كان هناك أنصبة فهناك مشاركة تكمل بعضها بعضا ، وهذا هو • المعنى المقصود

\section{ب) في الاصطلاح :}

من المعاني اللغوية السابقة ما يُنبئ ويُؤدي إلي المعنى المقصود وهو المشاركة والاقتسام والتوزيع ، بمعنى وجود قواسم مشتركة بين مجموعة من الأفراد

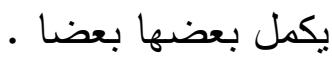

\section{خامسا : تعريف لفظ الحضارة :}

وردت مادة الكلمة ( ح، ض ، ر م ) في القرآن الكريم حوالي خمسة وعشرين

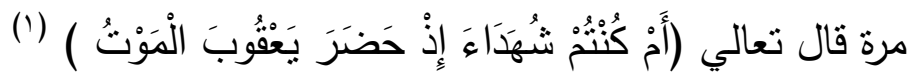

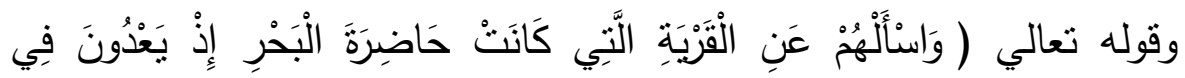

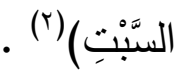

كما وردت في لغة العرب علي عدة معان منها :

( الإقامة في الحضر والتمدن ، وهي بخلاف البداوة، تقول العرب: تََبَبَّةَ

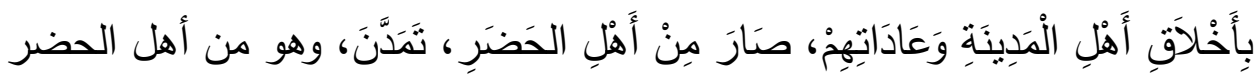

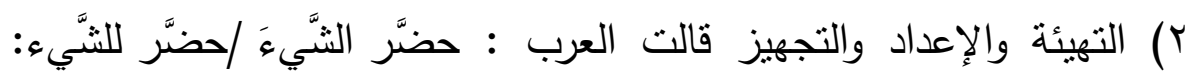
أعدَّه، هيَّأه، جهَّه.

r) الاستعداد:-- حضّر نفسَه: استعدّ (ץ).

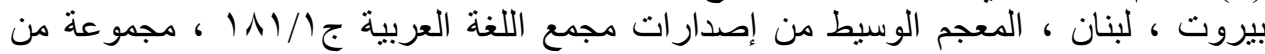

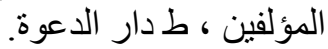

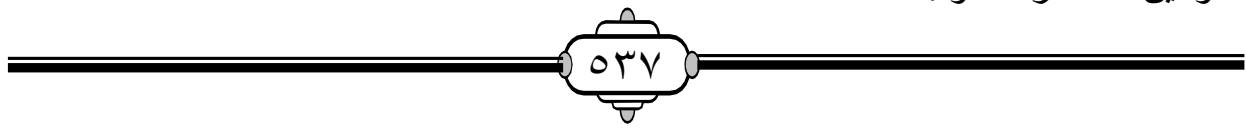


إن وضع تعريف محدد لمفهوم الحضارة لأمر صعب المنال ،وذللك لاختلاف كاف المنظور التقافي والفكري لكل صاحب تعريف ومن هنا تعددت التعريفات والتي منها: ( ) التفنن في الترف واستجادة أحواله والكلف بالصنائع التي نؤنق من أصنافه

\section{وسائر فنونه (') (1) - (1)}

r) جملة من مظاهر التقدم الأدبي، و الفني، و العلمي، و التقني التي تتنقل من جيل إلى جيل في مجتمع واحد أو عدة مجتمعات متشابهة ،وهي بهذا المعنى متفاوتة ،وهو التعريف الموضوعي ، أما المعنى الذاتي المجرد، هي مرحلة سامية • من مراحل التطور الإنساني المقابلة للبداوة r ) عدد من الإنجازات الملموسة والتي يكون لها تأثير في جميع المجالات الحياتية .

ع) ما يميز أمة عن أمة من حيث العادات والتقاليد وأسلوب المعيشة(؟). من تلك التعريفات يتبين لنا اختلاف وجهات النظر في تعريف الحضارة حسب الأزمان والأماكن ، فمنهم من ينظر إليها نظرة حسية ، ومنهم من ينظر إليها نظرة شاملة. أما التقاسم الحضاري فهو :- من خلال تعريف التقاسم والحضارة منفردين نستطيع أن نستخرج معنى التقاسم الحضاري فنقول : إن مولد أي حضارة وظهورها

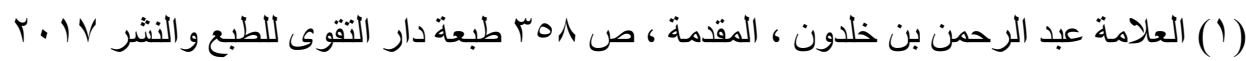

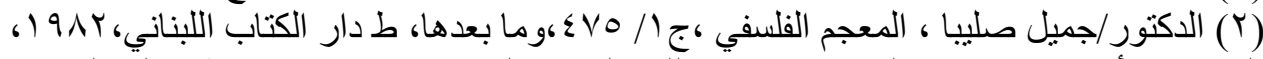

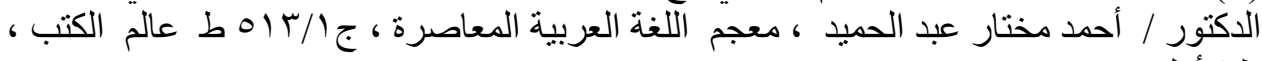

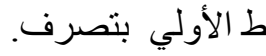


لا يبرز للعيان فجأة ،بل بعد جهد وبتأثنرات عدة تبعا لتأثثر طوائف اجتماعية ثلاثة

تأثثر عالم الأثخاص ، وتأثير عالم الأفكار ،وتأثثر عالم الأثياء وهذه العوامل لا تعمل منفردة بل نتوافق في عمل مشترك ،تأتي صورته من نماذج من عالم الأفكار (التقافة ) يتم تتفيذها بوسائل من عالم الأشياء ( المادة ) من أجل غاية يحددها عالم الأشخاص ،إذن نكوين أي حضارة إنما هو نتاج اجتماعي يستلزم توازن وتقاسم بين القوى الفكرية والعقائدية والمادية ، ولكل منها دوره في قيام الحضارة ، ولكل جانب من تلك الجوانب من يملكه ، فالمسلمون وأصحاب العقائد يملكون الثقافة والفكر الذي قامت به وعليه أعظم وأرقي الحضارات ،والتي قامت عليها الحضارة الغربية نفسها ،والجانب الغربي المادي(الحضارة الغربية المادية ) يمتلك زمام القوة والسلطة المادية على مستوى العالم والتي بدأت مرحلة الهبوط والانحدار لا بسبب فقدانها القوة المادية أو القوة الاقتصادية ولكن بسبب إفلاسها في عالم القيم السامية والأخلاق الفاضلة والمبادئ الإنسانية العادلة .. وبسبب فقدانها الهدف والمنهج القويم الذي نرتكز عليه الحضارات وبسبب انحرافها عن الطريق الصحيح ، والتي تحتاج إلي إصلاح من الجذور ، ،وعلي الرغم من ذلك فإنه من الممكن أن بكون هناك تقاسم بين الطرفين لقيام الحضارة ورقي الإنسانية ، وبتطبيق ذللك في مجال بحثنا فنحن نملك الإيمان بمعزات الأنبياء عليهم السلام فنحن المؤمنون بها وهي تراثنا الفكري ،ونملك مقومات الحضارة وأسسها من الفكر والثقافة ،والآخر يملك المادة والمال وبضم هذين الجانبين تقوم حضارة عظيمة يستفيد منها الإنسان علي مر العصور ،وبذلك يكون هناك تقاسم للحضارة وعوامل تساعد علي

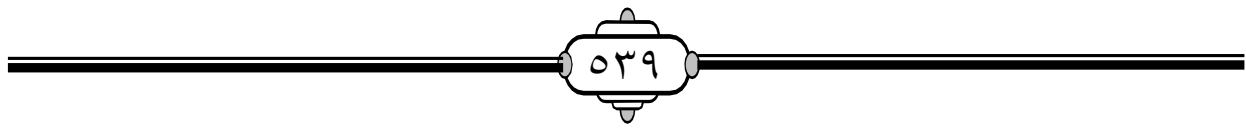




\section{تعقيب}

بعد التعرف علي مفهوم المصطلحات السابقة تبين لنا ، أنه من الممكن الجمع بين مصطلحات متباعدة لنصوغ منها موضوعا جديدا ،فبالنظر في معجزات الأنبياء عليهم السلام، الكثير يتتاولها كدليل علي صدق الأنبياء وتكذيب المعاندين ولا علاقة لها بالحضارة وبالأمور المعيشية للإنسان ، لكن بالبحث والتأمل في معجزات الأنبياء من زاوية شرعية عقلية تبين لنا ، أن للمعجزات معجزات ودور في إقامة الحضارة وإعمار الأرض والحث علي العمل ، لأنه ما نبي إلا وكان صاحب مهنة

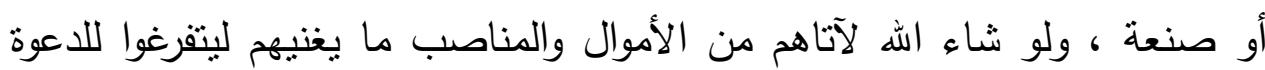
التي أرسلوا من أجلها ، ولكن أراد الله تعالي أن بعلمنا علي أيدي أنبيائه ورسله عليهم السلام العمل وأن يجعل فيهم القدوة في السعي وإعمار الكون ، فقد كان سيدنا داود عليه السلام نبياً وملكاً ومع ذلك علمه الله تعالي صناعة الدروع وآلان له

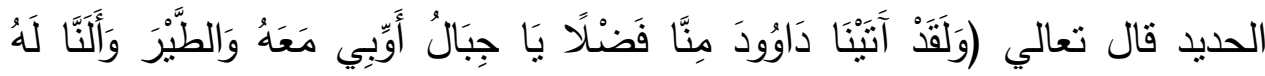

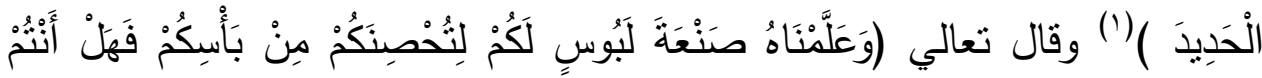
شَاكُرُونَ )(r أفكان التعليم من الهه تعالي ليعلموا هم الناس ، وهذا سيدنا نوح عليه السلام علمه الله تعالي صناعة السفن ليعلم الناس ويكون الأنبياء عليهم السلام هم

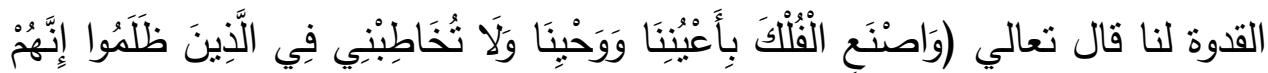
مُغْرَقُونَ )(r) وذلك أنه لم يكن يعلم كيفية صناعة الفلك ف فعلمه الله تعالي ، وسنأخذ

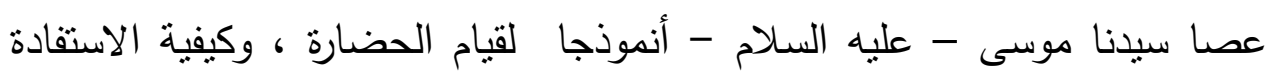
منها في الوقت الحاضر 


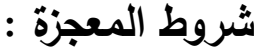

لكي يصدق علي الفعل أنه معجزة ، و يُفرق بينه وبين أي فعل آخر لابد أن تتوافر فيها عدة شروط ، ومن شروط المعجزة : ( ) أن تكون المعجزة فعلا لله تعالي أو ما يجري مجرى الفعل :

أي ليس للنبي اختيار في فعله أو تركه وإن أظهرها الله على يديه ، وهي آية وبرهان وسلطان من الله تعالى لتصديق نبيه ، سواء كانت قولاً كمجزة القرآن

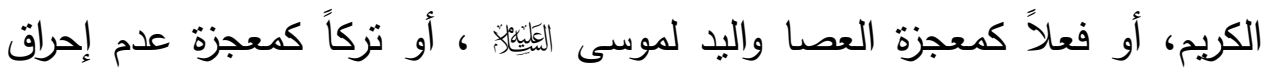

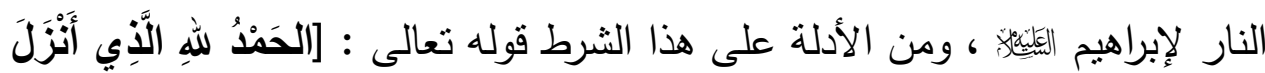

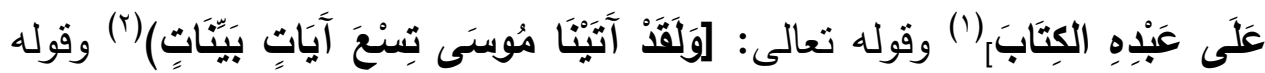

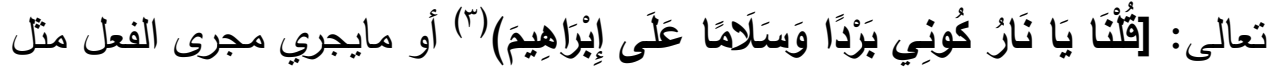
" فلو قال نبي آية صدقي أني في هذا اليوم أحرك أصبعي ولا يقدر أحد من البشر

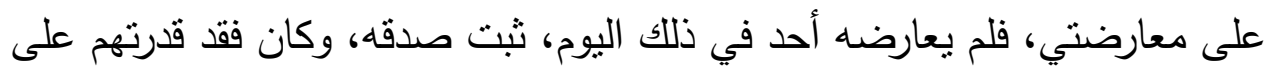
الحركة مع سلامة الأعضاء من أعظم المعجزات(ء).

r أن تكون المعجزة أمرا خارقا للعادة :

أي مخالفاً لما اعتاده الناس وألفوه ،لأن المعجزة لابد من اختصاصها بالنبي، ليمتاز به عمن ليس بنبي ، والأمر المعتاد مما يشترك فيه الكل ، فكيف يدل

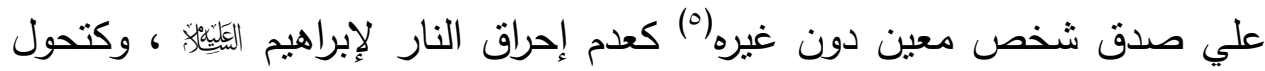

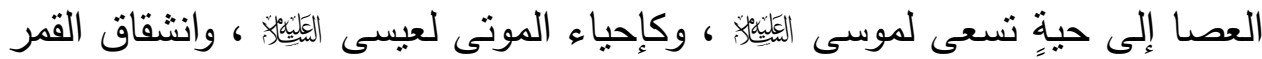

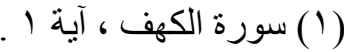

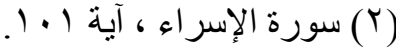

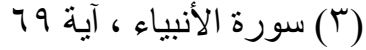

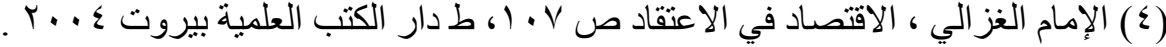

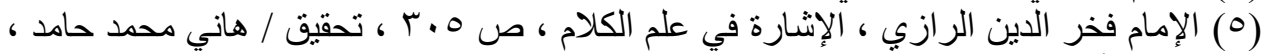

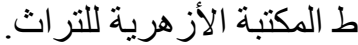




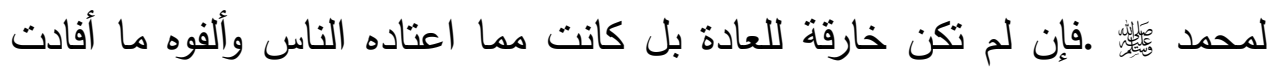

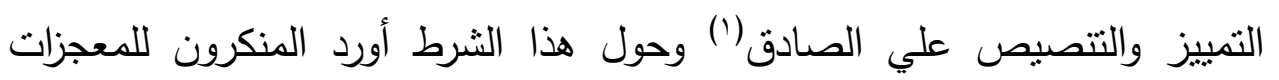

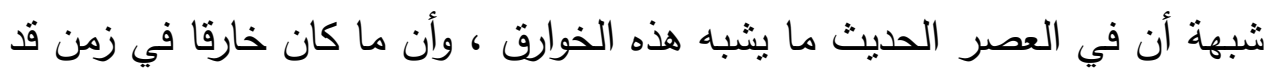

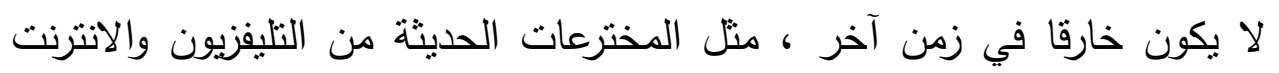
والتليفون التي لو ظهرت من قرن و نصف القرن لتخيلها الناس من خوارق العادة فليس هذا الثرط مما يميز المعجزة ، وقد عبر عن هذا الأمر الإمام الجويني بقوله:

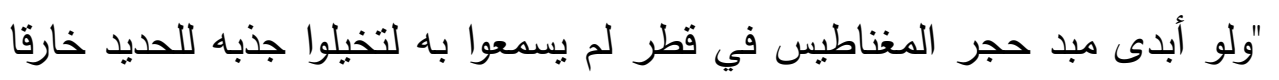

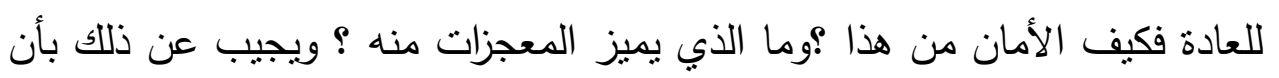

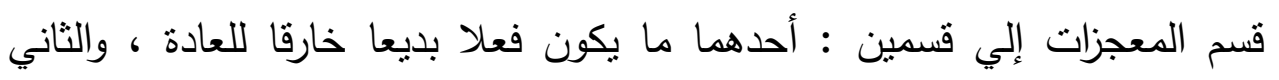

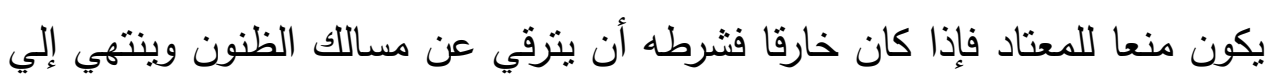

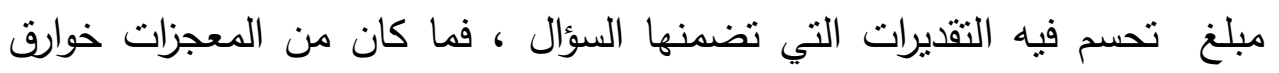

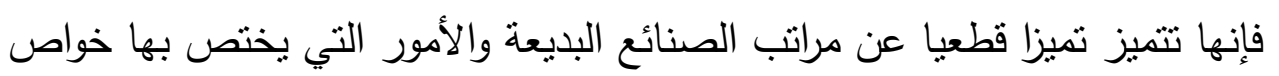

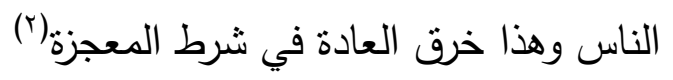

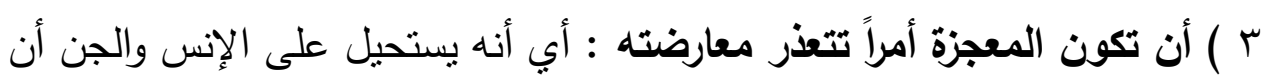

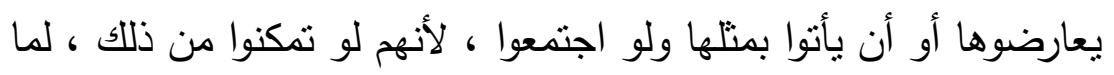

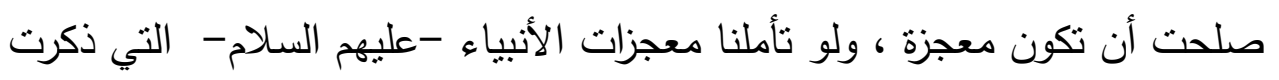

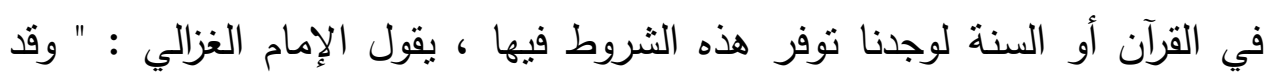

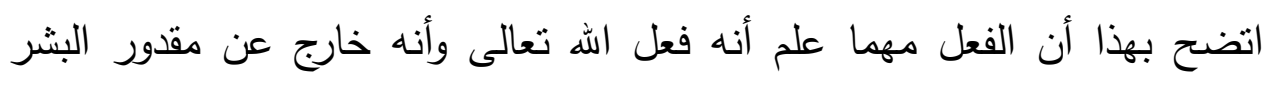
واقتنرن بدعوى النبوة حصل العلم الضروري بالصدق وكان الثنك من حيث الثثك في الثي

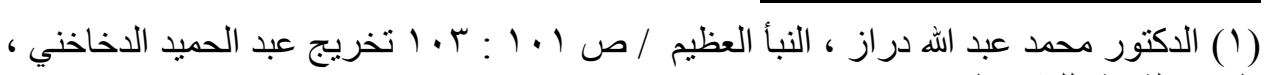

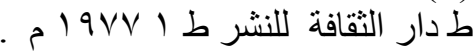

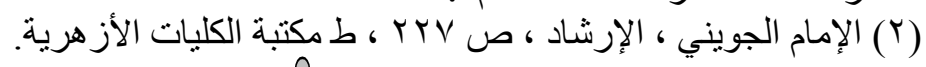
Oि 
أنه مقدور البشر أم لا، فأما بعد معرفة كونه من فعل اله تعالى لا يقى للثك مجال

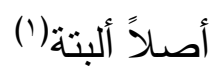

وبهذا الثرط تخرج أمور أربعة وهي السحر والثعبذة والكهانة وغرائب المخترعات(؟)

\section{؛) أن تكون قد ظهرت على يد مدعي النبوة :}

فإذا جري أمرٌ خارق للعادة علي يد غير مدع للنبوة فلا يكون معجزة

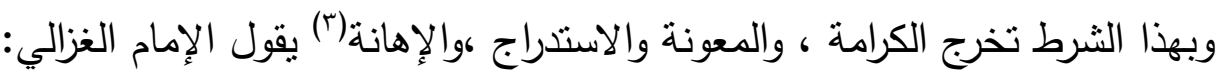
فإن قيل فهل تجوزون الكرامات؟ قلنا: اختلف الناس فيه، والحق ذلك جائز فإنانه

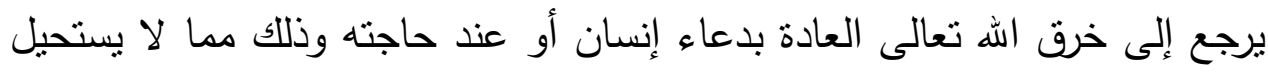

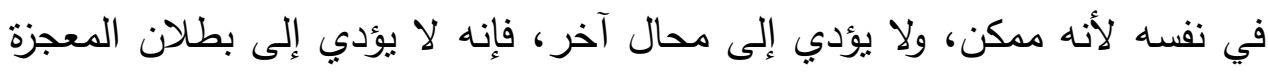

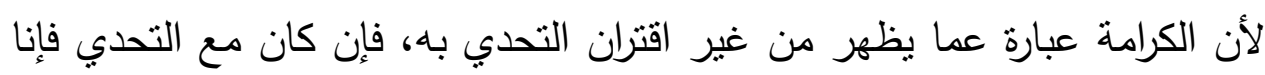
نسميه معزة ويدل بالضرورة على صدق المتحدي؛ وإن لم تكن دعوى فقد يجوز

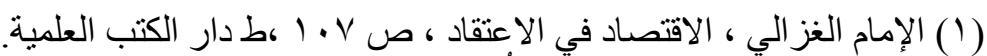

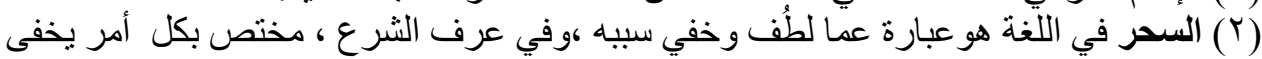

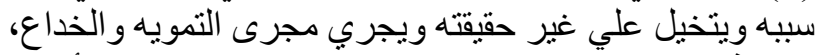

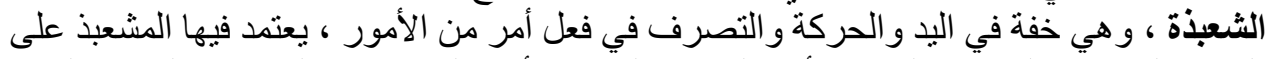

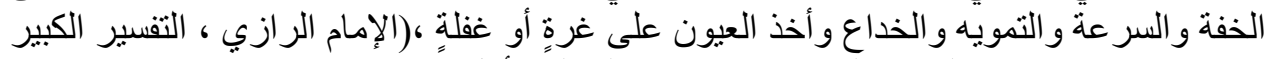

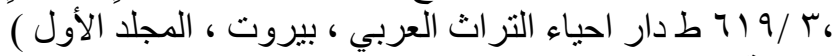

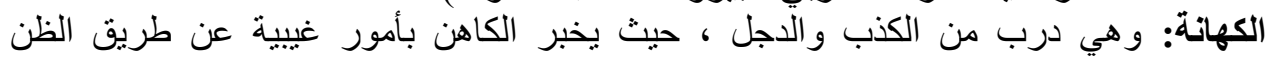

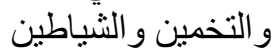

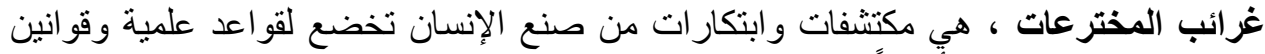

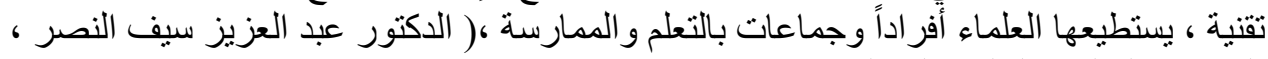

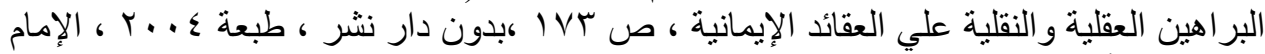

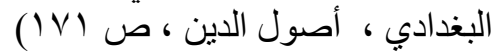

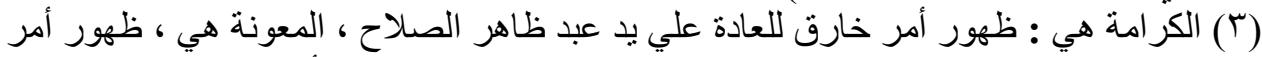

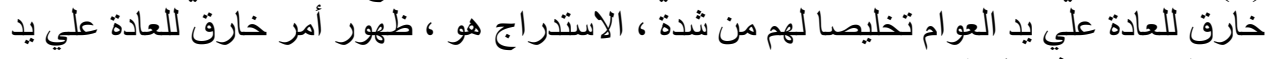

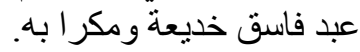

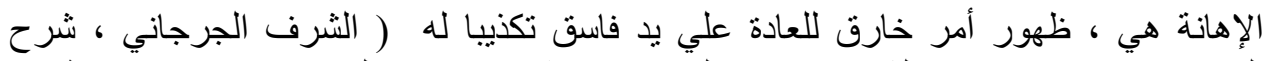

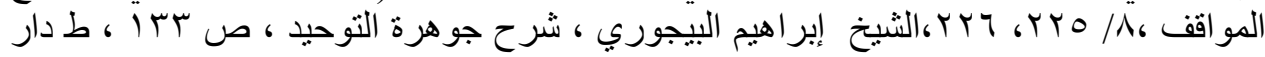

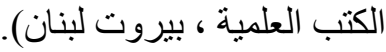

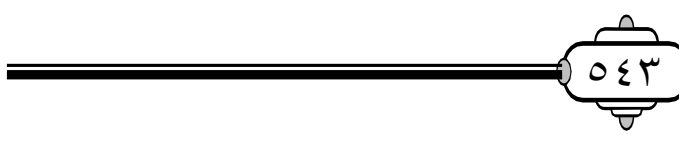


ظهور ذلك على يد فاسق لأنه مقدور في نفسه؛ فإن قيل: فهل من المقدور إظهار معجزة على يد كاذب؟ قلنا: المعجزة مقرونة بالتحدي منه سبحانه نازلة منزلة قوله صدقت وأنت رسولي، وتصديق الكاذب محال لذاته وكل من قال له أنت رسولي صار رسولاً وخرج عن كونه كاذباً، فالجمع بين كونه كاذباً وبين ما ينزل منزلة قوله أنت رسولي محال لأن معنى كونه كاذباً أنه ما قيل له أنت رسولي، ومعنى المعجزة أنه قيل له أنت رسولي؛ فإن فعل الملك على ما ضربنا من المثال كقوله أنت رسولي بالضرورة، فاستبان أن هذا غير مقدور لأنه محال والمحال لا قدرة عليه(1) •) أن تكون المعجزة موافقة لما ادعاه النبي: فلأنّ الخارق لو ظهر على يد غير مدّعى النبّوّة، أو على يده لكن على خلاف ما

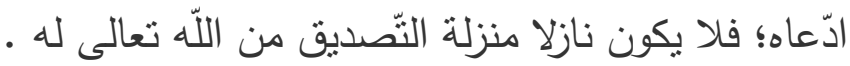
؟) أن تكون المعجزة بعد ادعاء النبوة، وليس قبلها : لأن ما يحدث قبلها من خوارق العادات فهو إرهاص لتهيئة النبي والناس لنبوته فيما

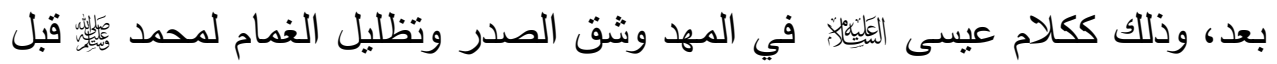
البعثة، أما الإمام الآمدي فيعدها كرامات فيقول "كل خارق ظهر على يد النّبيّ قبل بعثثه؛ فهو من باب الكرامات والأنبياء عليهم السلام قبل البعثة لا يخرجون عن

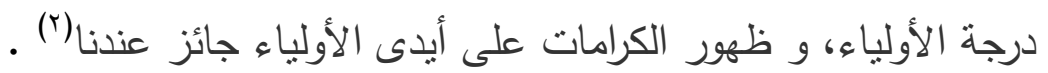

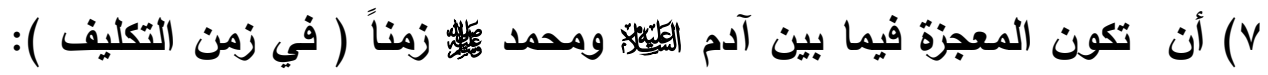

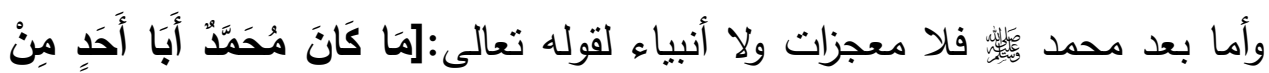

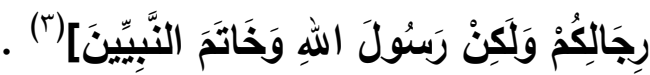

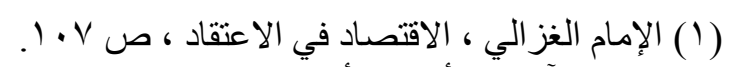

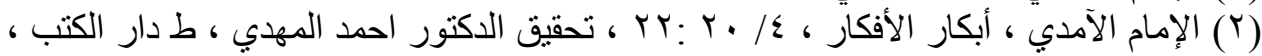




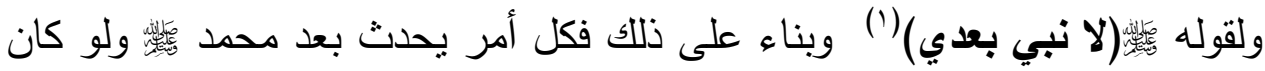

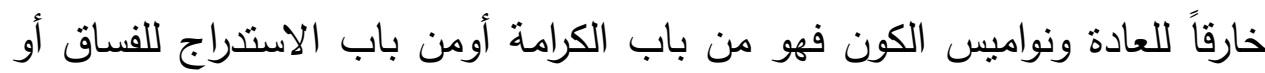
الكفار، كالخوارق التي يجريها الله على يد الدجال كإحياء الموتى ، أو ما يظهر عند ظهور أشراط الساعة، وانتهاء التكليف لا يشهد بصدق الدعوى لكونه زمان نقض العادات وتغير الرسوم(r) (ب)

وبهذه الثروط يخرج كل ما يسميه الناس معجزة لغرابته، فهناك كثير من الناس خلطوا بين المعجزة والكرامة والسحر والاختراع العلمي، خاصة في ظل التقدم العلمي ووجود الكثير من المخترعات التي ظن أصحابها أنها مماتلة لمعجزات الأنبياء ،كما أن هناك من أنكر معجزات الأنبياء بسبب تلك المخترعات، إلا أن الأمر ليس كذلك ، لأن هناك فروقا بين المعجزة ، وبين ما عداها من الخوارق

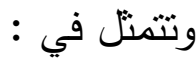

I - من حيث التعريف وقد ذكرت تعريف كل واحد من هذه الخوارق r- أن المعجزة تكون علي يد النبي ، والأنبياء لا يكونون إلا ذكورا ، أما بقية

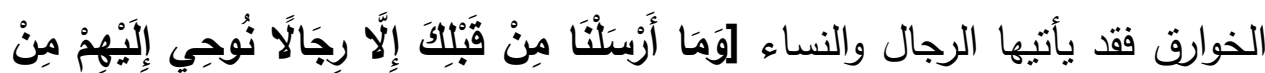

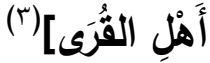

r- إن المعجزة هي فعل الله تعالي ، فلا تأتي بالتعلم والاكتساب ، أما بقية الخوارق

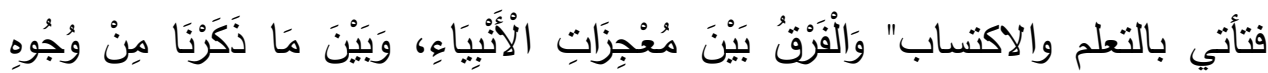

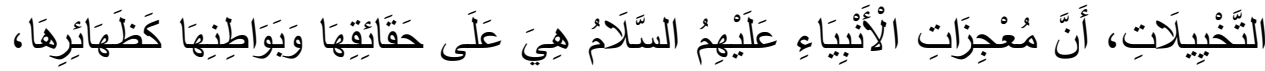

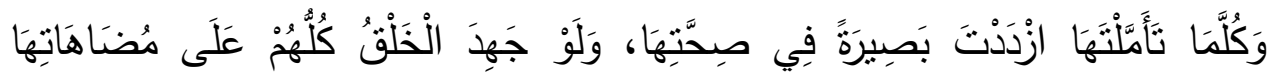

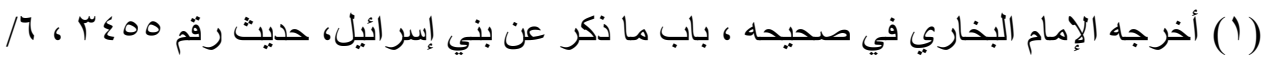

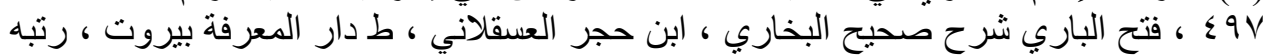

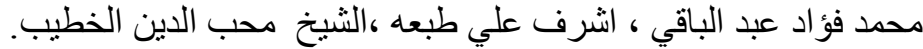

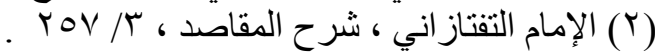

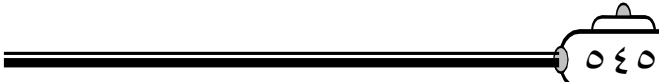




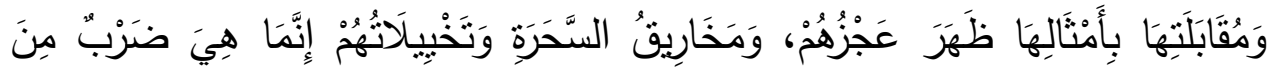

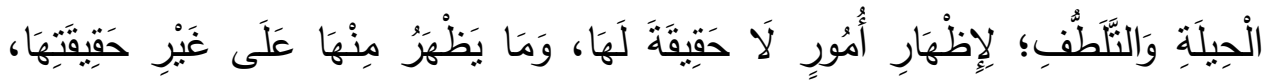

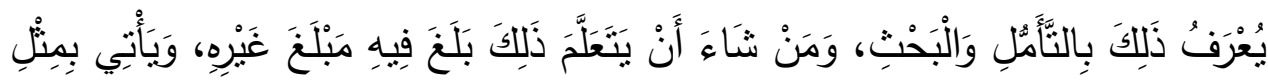

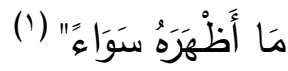
؟ - أن معجزات الأنبياء يمكن عدها وحصرها من خلال الأخبار الصادقة اليقينية، أما بقية الخوارق فلا يمكن حصرها ،لأنه يتطرق الكذب في نقل أخبارها" إن الن الناهن

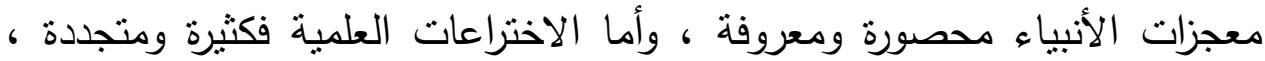
وتمضى الأيام حُبلي بكل جديد ومبتكر منها.

ومن هنا فالمعزة أعظم من المكتثفات الحديثة ،بل أصغر المعزات يصغر بجانبها أعظم مكتشفات العلم الحديث ،لأن الدعزة لابد أن تكون خارقة لنظام العالم وإلا لا تكون معزة بمعناها الحقيقي • 0- أن المعزة تتعذر معارضتها ، أما بقية الخوارق فلا . 7 - المعجزة فيها خير الناس وصلاحهم وهدايتهم ، وأما الاختراع العلمي فقد يكون

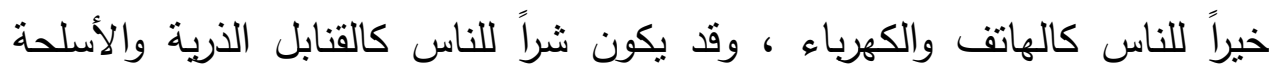

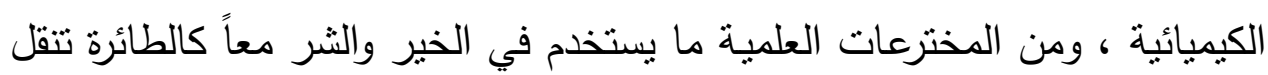

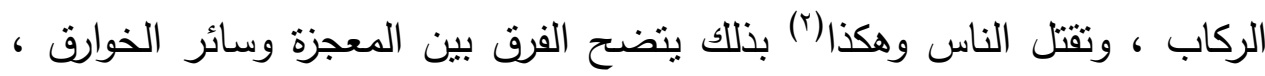
كما أن الخوارق منها ما يكون للتأييد كالإرهاص والمعجزة والكرامة والمعونة ، ومنها لإنال ما يكون بالتعلم كالسحر والثعبذة ، ومنها ما يكون للتكذيب كالاستدراج والإهانة ، التهانه

(1) الإمام الجصاص أحكام القرآن ج 1 / .7، ط دار إحياء التراث العربي بيروت ، تحقيق/

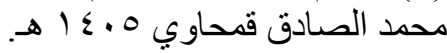

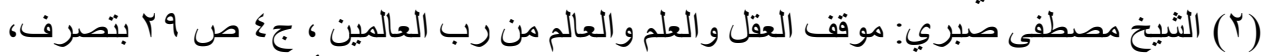

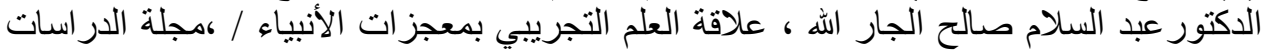

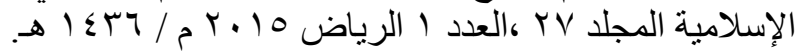

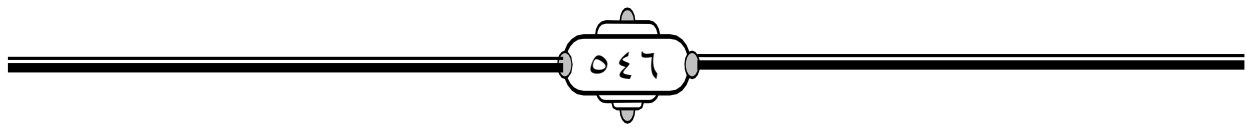


علاقة معجزات الأنبياء بالتقاسم الحضاري

وبهذا يتضح لنا الفرق بين المعجزة كدليل علي قدرة الله تعالي وكدليل علي صدق

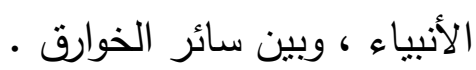

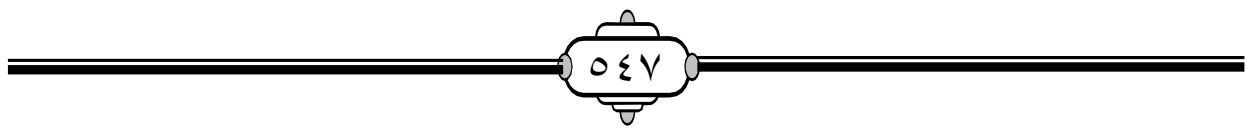


الأفصل الثاني

دورالمجحزة في إثبات النبوة

وبتشنمن:

اـ دور المعجزة في إثبات النبوة بوجه مام ثم حال حياة النبي.

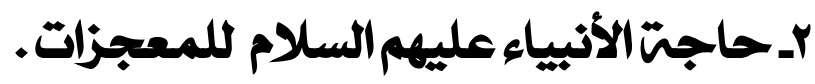

rـ تأبيدهم بمعجزات مناسبت.

ع هل وقع بها ولها التحمليوي.

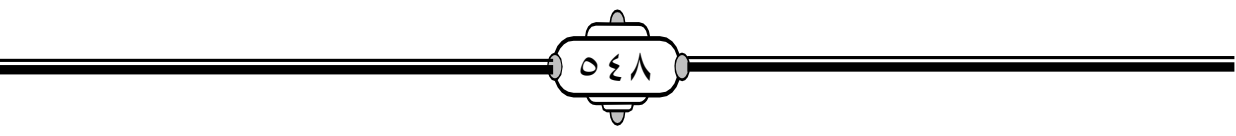




\section{الفصل الثاني}

\section{دور المعززة في إثبات النبوة}

أولا : دور المعجزة في إثبات النبوة بوجه عام ، ثم حال حياة النبي :

إن الحديث عن دلائل إثبات النبوة للأنبياء قد اتسع ،و حدث فيه خلاف بين مفكري المسلمين في هذه الطرق ، فمنهم من قال بتعدد هذه الدلائل كالمعجزات،

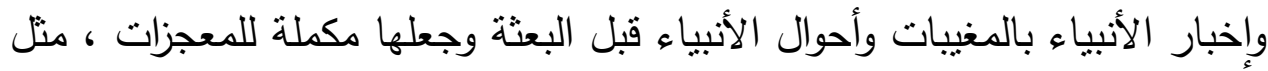
الإمام الماتريدي والإمام البيضاوي والإمام التفتازاني ،كومنهم من حصرها في المعززات فقط مثل الإمام الجويني ، ومنهم من زاد علي ذلك كأخلاق الأنبياء وأوصافهم وكمالاتهم والوحي والبشارات، وجعلها دلائل مستقلة كالإمام الطحاوي ومن تبعه ، وإليكم بعض التفصيل.

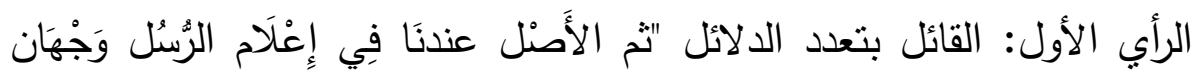

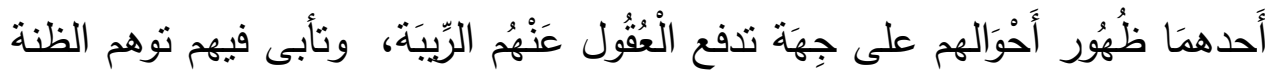
بِمَا صحبوهم فِي الصغر وَالْكبر فوجدوهم ظَاهِرين أصفياء أتقياء بَين أظهر قوم مَا

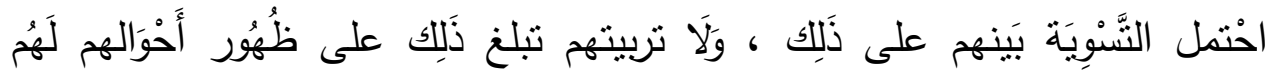

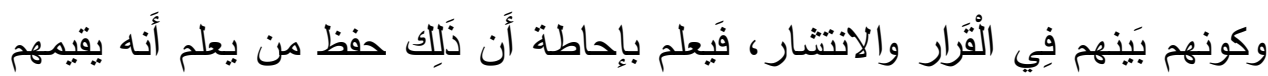

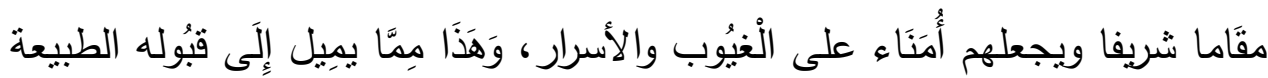

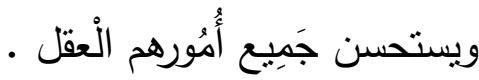

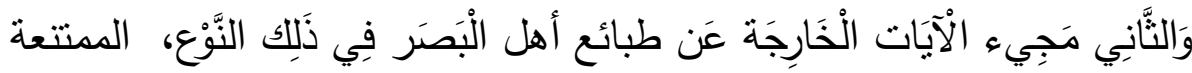

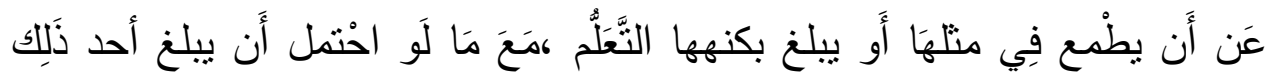

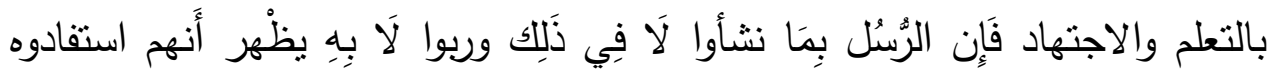

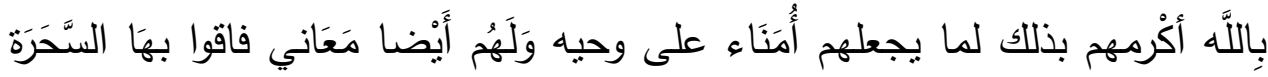

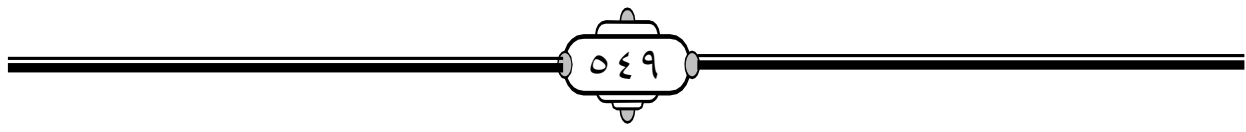


على أَن علم السحر أَصله من السَّمَاء لَكِن النَّاس نسوا أَصله وتوارثوه بالتعلم وَكَذَللِكَ المكاسب والحرف والصناعات كلهَا (') أما الإمام التقتازاني فيقول : " لا خفاء في ثبوت النبوة بخلق العلم الضروري كعلم الصديق رضي الله عنه ، وبخبر من ثبتت عصمته عن الكذب كنصوص التوراة والإنجيل في نبوة نبينا عليه السلام .... واما ما سيأتي من الاستدلال علي نبوة محمد صلى الله عليه وسلم بما

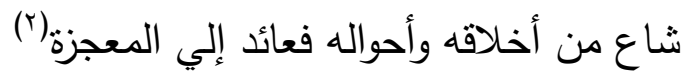
وممن يقول بعدم حصر دلائل النبوة في المعجزات ، الإمام الثهرستاني فيقول: لا ينحصر طريق التعريف في المعجزات ، بل يجوز أن يخلق لهم علماً ضرورياً بصدق النبي ، فلا يحتاج المنكر إلى طلب المعجزة ليعرف بها صدقه أو ينصب لهم أمارات أخر غير خارقة للعادة ، لكن يتبين لواحد بحكم قرينة أورثت علماً لشخص ولم تورث علماً لغيره، أو يخبر من استأهله لسماع كلامه فيعلم صدقه كما أخبر الملائكة " إني جاعل في الأرض خليفة " وإذا ثبت صدقه عندهم إما بالخبر أو بتعليم الأسماء لزم تصديقه على كل من خلف بعدهم ، وإذا أخبر من ثبت صدقه إنه بدليل ما عن صادق آخر يخلفه وجب تصديقه ، وكذلك الخبر عن كل صادق بشارة لمن بعده وإعلاماً للخلق بآيات في خلقه وصورته وقوله وفعله ،ووجب على كل من سمع ذلك تصديقه بإخبار الأول ،ولهذا أخبر التنزيل عن منل هذه الحالة على لسان

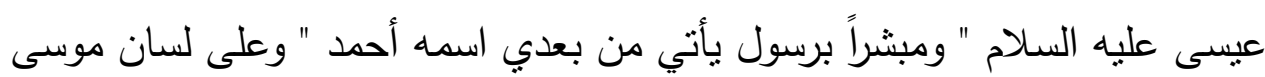
عليه السلام " النبي الأمي الذي يجدونه مكتوباً عندهم في التوراة والإنجيل " الآية وعلى لسان الخليل عليه السلام " ربنا وابعث فيهم رسولاً " الآية وأماراته في التوراة

(1) الإمام الماتريدي ، التوحيد ، 111 ، 119 ، ط دار الجامعات المصرية بالإسكندرية ، تحقيق الدكتور فتح الله خليف.

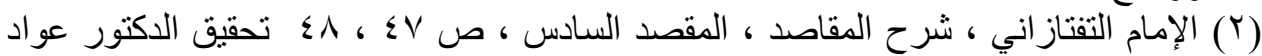

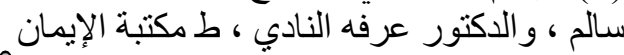


والإنجيل أكثر من أن تحصى ، فلو لم يظهر النبي معجزة قط كان ما مضى من لمن

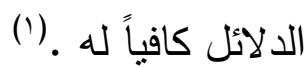

\section{الرأي الثاني : من حصر الالائل في المعززات :}

منهم الإمام الجويني حيث يقول : إنَِّّا يثبت صدق مدعي النُبُوَّة بالمعجزات

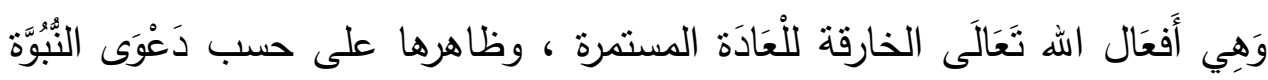

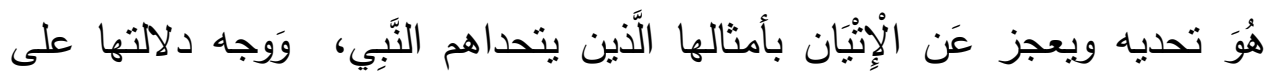

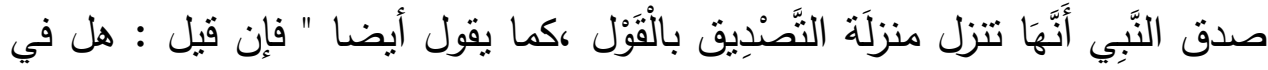
المقدور نصب دليل علي صدق النبي غير المعزة ؟ قلنا : ذللك غير مدكن ، فإن

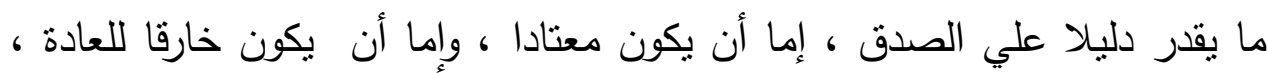
فإن كان معتادا ، يستوي فيه البر والفاجر، فيستحيل كونه دليلا ، وإن كان خارقا للعادة ، يستحيل كونه دليلا دون أن يتعلق به دعوى النبي ، إذ كل خارق للعادة يجوز تقدير وجوده ابتداء من فعل الله نعالى ، فإذا لم يكن بد من تعلقه بالدعوى ،

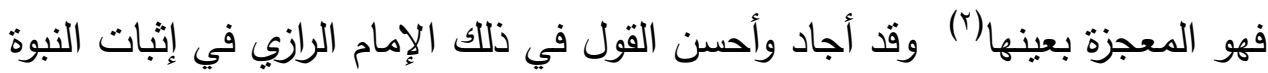
للأنبياء عليهم السلام ، والرد علي شبهات المنكرين فقال : "إن العاقل إذا أحكم

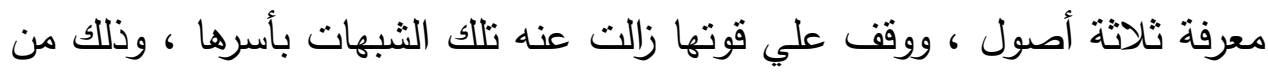
كمال نعم اله علي العباد ، حيث هداهم إلي تللك الأصول الثلاثة ليتوسلوا بها إلي

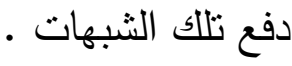

الأصل الأول: أن القول بإثبات النبوات فرع علي القول بإثبات الفاعل الخختار ،

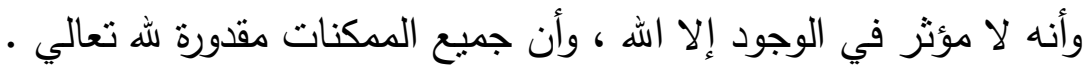

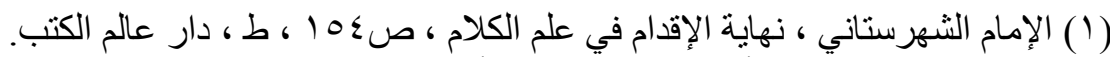

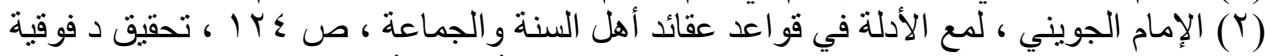

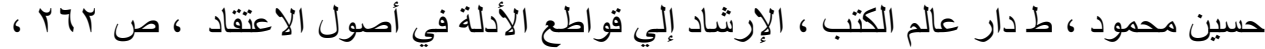

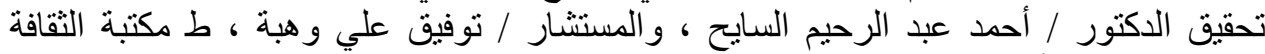

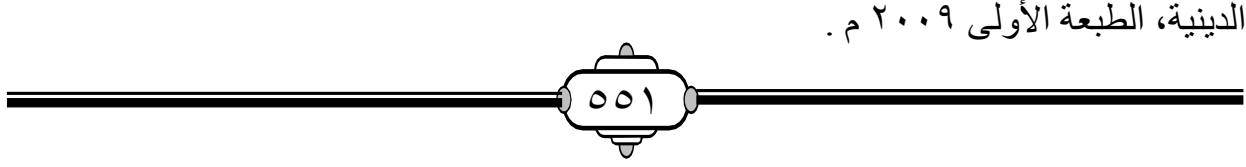




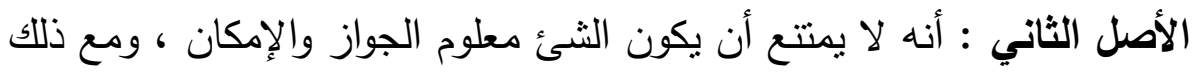

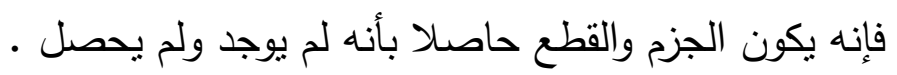

الأصل الثالث : أن تعلم أن تحسين العقل وتقبيحه باطل ، لا عبرة به ولا

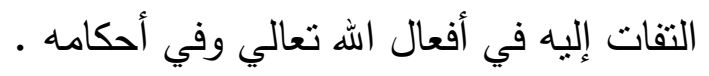

فإذا عرفت هذه الأصول فحينئذ يظهر القول بصحة النبوة ظهورا لا ييقى فيها

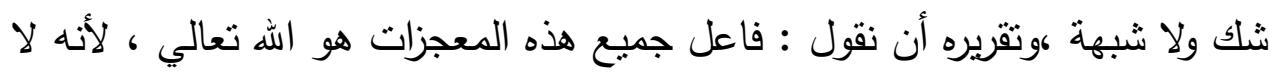

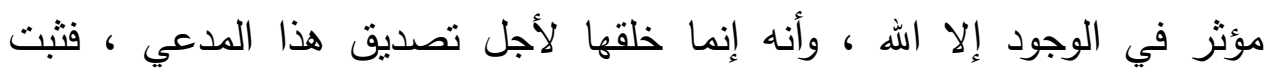

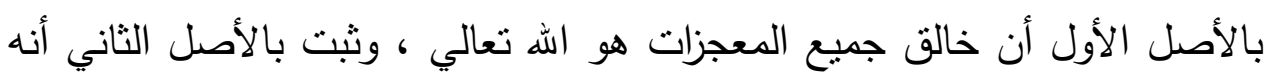

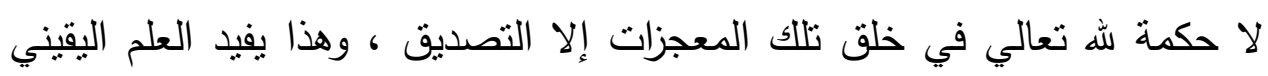

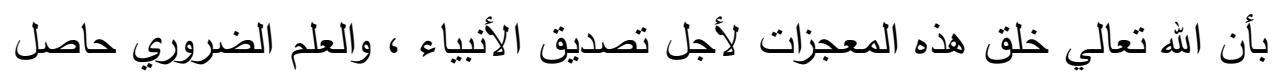

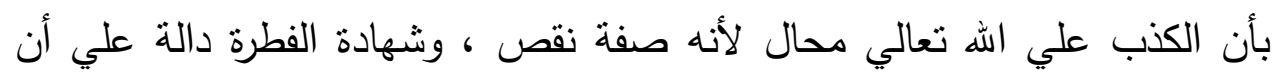
صفة النقص محال علي الله تعالي ، وعند هذا بحصل الجزم واليقين بأن ظهور

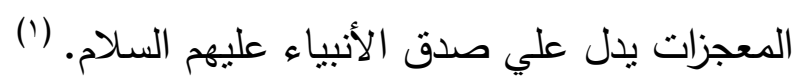

نخلص من تلك الآراء إلي أن المعجزة هي الدليل الوحيد المتفق عليه في إثبات

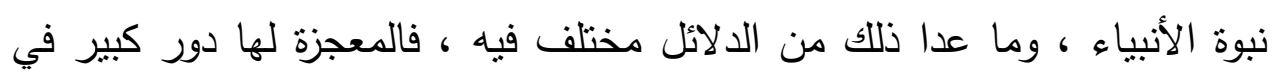

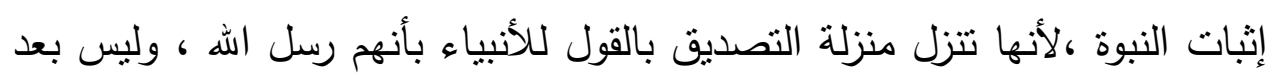

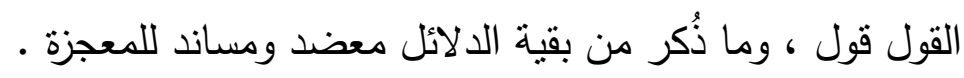

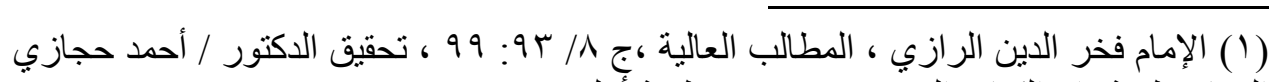

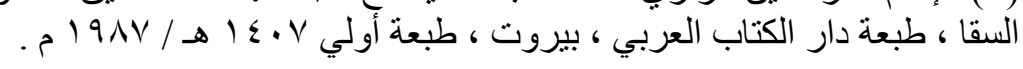

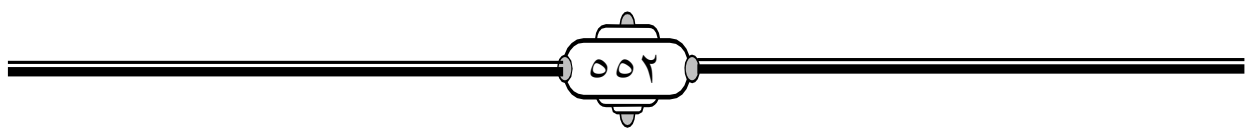




\section{ثانيا :- حاجة الأنبياء عليهم السلام لمعززات مناسبة:}

إن الله جل ثناؤه اصطفى أنبياءه من خلقه، وأكرمهم بالنبوة، وبعثهم إلى أقوامهم

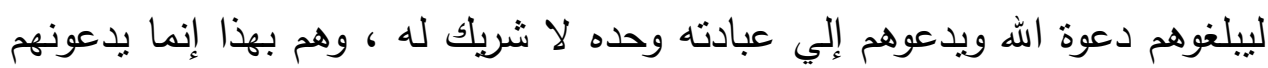
إلى تغيير عقائدهم من الكفر والثرك إلى الإيمان ، وعبادتهم للأصنام والأوثان إلى لى

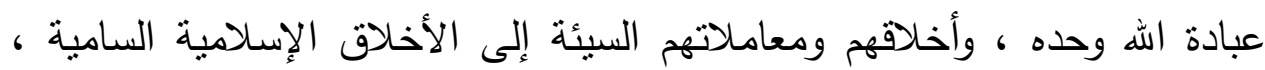

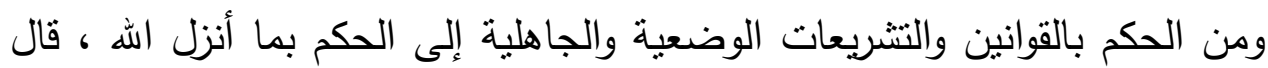

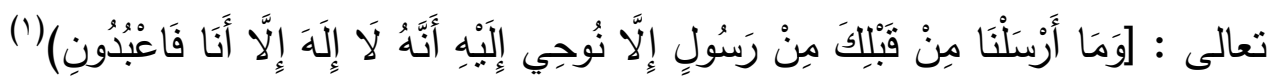
واقتلاع المعتقدات الفاسدة ، وبناء العقيدة السليمة ، وقد كان هذا بمثابة خطب جلل وأمر خطير، وانقلاب عظيم يجابه به أب نبي قومه ، لأنه يبطل غالب ما هم عليه ، ويقلب حياتهم رأسا على عقب ، فمنهم من يؤمن وهم قلة وكثير دفعهم التكبر إلي تكذيب النبي في دعواه من أول وهلة ، ومن هنا كانت حاجة الأنبياء عليه السلام ماسة جداً لآية وبرهان وسلطان ودليل وحجة- وهو ما نسميه معجزة- لإثبات

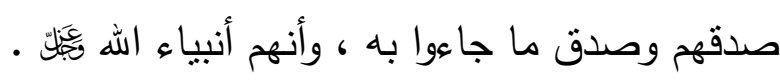

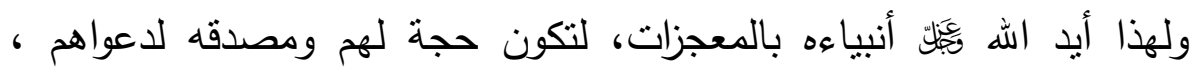

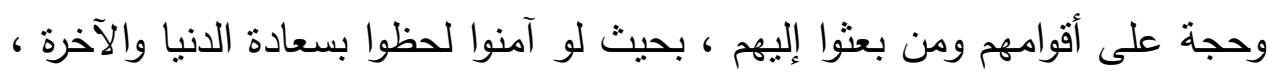

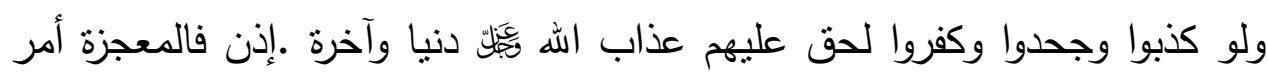
ضروري لإثبات النبوة ." ثم إن كل نبي من الأنبياء عيهم السلام إنما أوتي آية

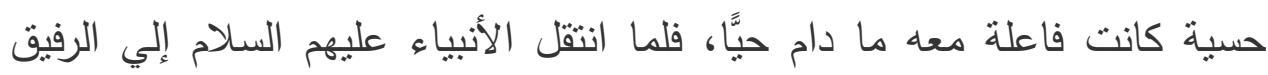
الأعلى انقطعت بموتهم المعجزات فلم تحدث بعد موتهم باعتبارها أمراً خارقاً للعادة ، لا يحدث إلا لنبي يُوحى إليه من قبل الله تعالي ، حتى جاء نبينا صلى الله عليه وسلم بمعزة القرآن الباقية بقاء الدهر، وانتقل صلى الله عليه وسلم إلى الرفيق

(1) (1) سورة الأنبياء ، آية ، 01.

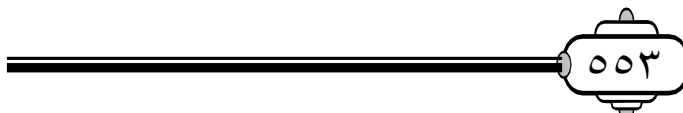


الأعلى وبقيت معجزته سراجًا منيرًا، وشاهدًا ودليلًا على خلود هذا الدين، وأنه الدين الذي ارتضاه سبحانه لعباده، والذي لا يقبل من أحد سواه ، إذ وظيفة الآية للأنبياء إثبات صدقهم وبلاغهم عن ربهم، فبها يؤمن الكافرون، وبها يهتدي الضالون .

\section{ثالثا: تأييد الأنبياء بمعجزات مناسبة:}

الله سبحانه وتعالي حكيم ، لا يصدر عنه قولٌ أو فعلٌ إلا عن حكمة بالغة ،

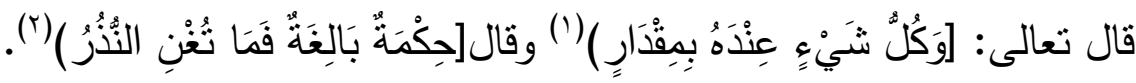

وقد اقتضت حكمته أن يؤيد كل نبي بما يناسبه من المعجزات عدداً وزماناً

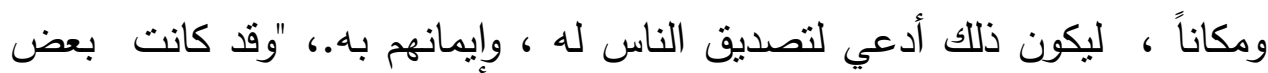
المعززات لبعض الأنبياء من باب التشريف والتكريم كنبع الماء من بين أصابعه الثريفة وحنين الجذع ،وبعضها آيات نرغيب وتأليف لبعض من في قلوبهر استعداد لقبول الهداية فتجذبهم بعض هذه الآيات والأعاجيب إلي حظيرة الإيمان ،حتى تضئ عقولهم وأفئدتهم إلي ظل الهداية ظليل ومن ذلك ما رواه البخاري في صحيحه عن

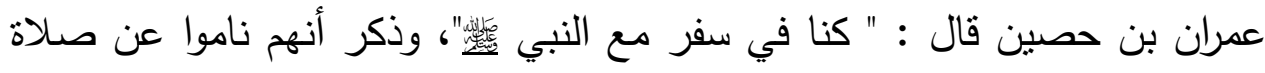
الصبح حتى علت الثمس ، فارتحلوا ثم نزلوا فصلوا مع النبي فلم يصل فسأله النبي جنابة ولا ماء ، فقال : عليك بالصعيد فإنه يكفيك ، ثم سار النبي ئس فثكى إليه الناس من العطش ، فنزل فدعا عليا وآخر معه وقال لهما " اذهبا فابتغيا الماء ، فانطلقا فتلقيا امرأة بين مزادتين أو سطيحتين من ماء علي بعير لها فقال لها : أين الماء ؟قالت: عهدي بالماء أمس هذه الساعة ونفرنا خلوفا ،قالا لها انطلقي إذن قالت : إلي أين ؟ قالا : إلي رسول الله 


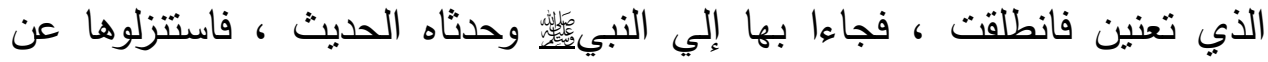

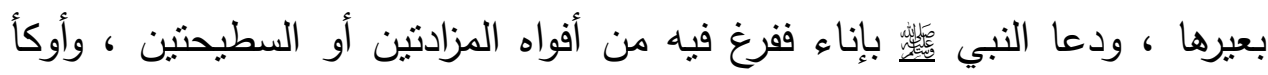
أفواههما وأطلاق العزالي ، ونودي في الناس : اسقوا واستقوا ، فسقى من سقى بهى واستقى من استقى ، وكان آخر ذاك أن أعطى الذي أصابته الجنابة إناء من ماء وقال : اذهب فأفرغه عليك ، وهي قائمة تتظر إلي ما يفعل بمائها ، وأيم الله لقد

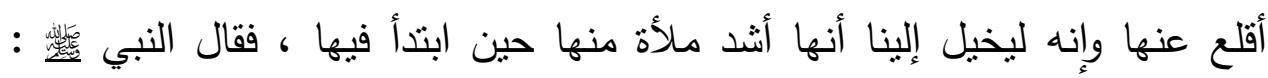
اجمعوا لها ، فجمعوا لها من بين عجوة ودقيقة وسويقة ، حتى جمعوا لها طعاما فجعلوها في ثوب وحملوها علي بعيرها ووضعوا الثوب بين يديها ثم قال لها " تعلمين ما رزأنا من مائك شيئا ولكن الله هو الذي أسقانا ، فأتت أهلها وقد احتبست عنهم ، قالوا : ما حبسك يا فلانة ؟ قالت : العجب لقيني رجلان فذهبا بي إلي هذا الذي يقال له الصابئ فقعل بي كذا وكذا ،فو الله إنه لأسحر من بين هذه وهذه تعني السماء والأرض- أو إنه لرسول الله حقا ، فكان المسلمون بعد ذلك يغيرون علي من حولها من المشركين ولا بصييون الصرم الذي هي منه ، فقالت يوما لقومها: ما أرى أن هؤلاء القوم يدعونكم عمدا ، فهل لكم في الإسلام ، فأطاعوها

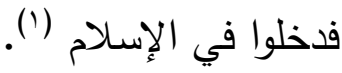

وبعضها كان للتحدي كالقرآن الكريم وبعضها نسرية كالإسراء والمعراج لسيدنا

محمد ئسئ، وبعضها مادي حسي وبعضها معنوي عقلي ، حسب عقول المبعوث فيهم ونفوسهم البشرية ، الله أعلم حيث يجعل رسالته ، ومن هنا جاء التتوع في المعزات فلو كانت كلها للتحدي لكان للنبي صلي الله عليه وسلم عناية وكفاية

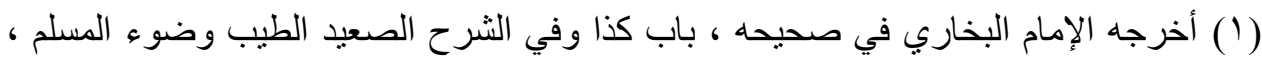

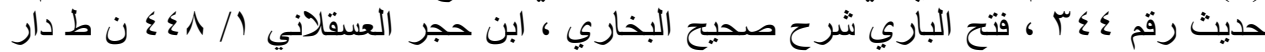

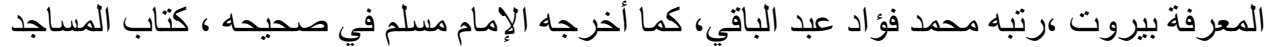

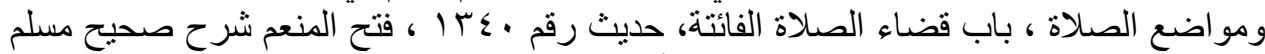

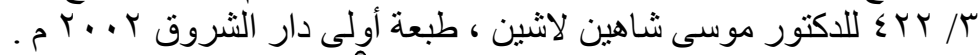


بالقرآن معجزة عن بقية المعجزات ولكانت بقية المعجزات عبثا(') فمثناً سيدنا إبراهيم اليَلِّهِ أيده الله بمعجزة عدم إحراق النار له ، وهذا أمر خارق للعادة ، حيث أبطل الله

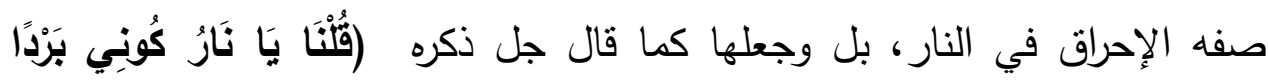

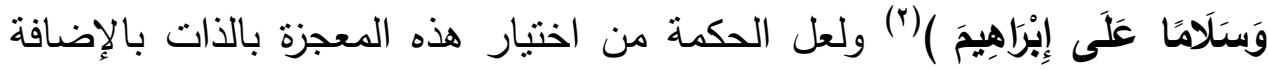

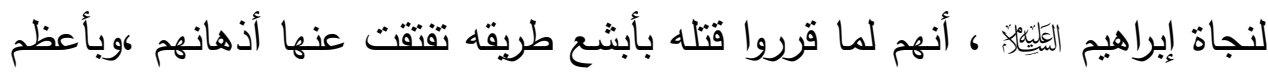

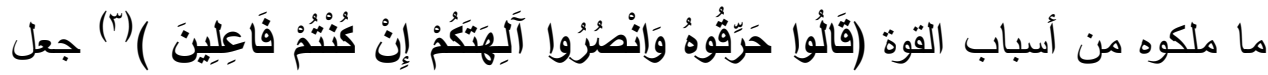
الله معجزته من جنس مكرهم وقوتهم ، فأبطل سرالإحراق في النيران ، بل وجعلها

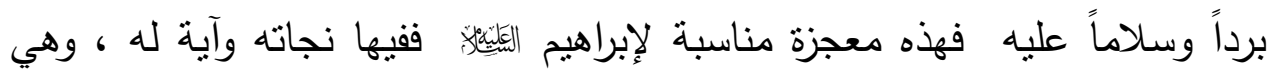
مناسبة لقومه ففيها إبطال لمكرهم وإعجاز لهم وحجة عليهم وإثبات لقدرة الله تعالي ، وهذا سيدنا موسى المَلِيَّة الذي أرسله الله تعالي إلى الفراعنة الذين ملكوا مصر وأنشأوا فيها حضارة وثثية حجرية انتشر وعلا فيها السحر والسحرة ، فاقتضت حكمته أن أن تكون معجزته من باب ما ييطل السحر ويقهره.

وبذلك تبرز الحكمة وتتضح من اختيار معجزة العصا بالذات لموسى اليَلئلة) ،

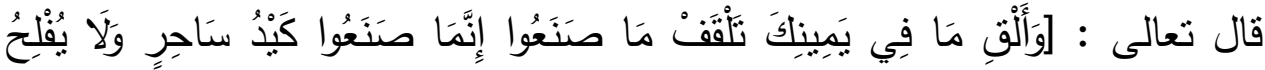

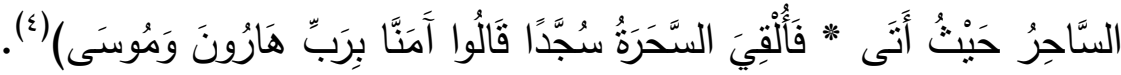

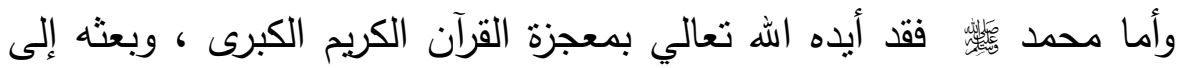
العرب أولا وهم أرباب اللغة، وأهل الفصاحة والبلاغة والبيان والثعر والنثز وتحداهم

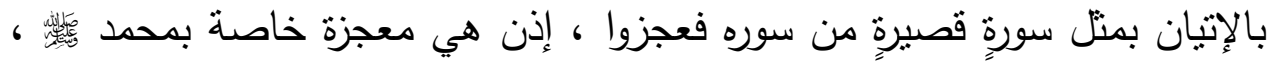
وعامة لجميع الناس، وتأثيرها ماضٍٍ والتحدي بها قائم إلى يوم القيامة قال تعالى : (1) الثيخ ، محمد الصادق عرجون ،محمد صلي الله عليه وسلم منهج ورسالة، / / 01، 09 هدية

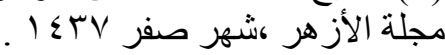

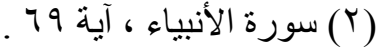

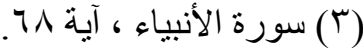

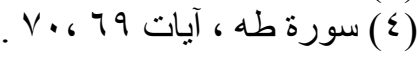




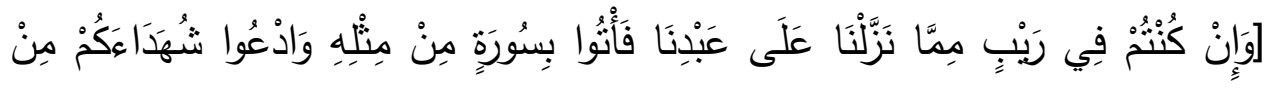

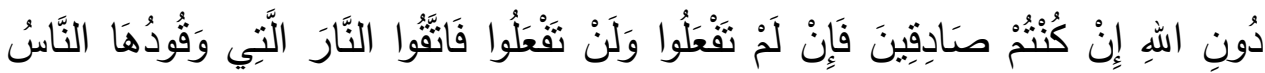

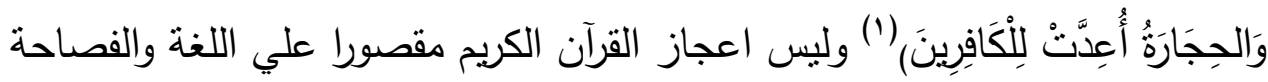
فقط ، وإنما شامل لوجوه عديدة بلغت في العد الكثير منها ما ذكره الإمام الباقلاني"أحدها يتضمن الإخبار عن الغيوب وذلك مما لا يقدر عليه البشر ولا سبيل

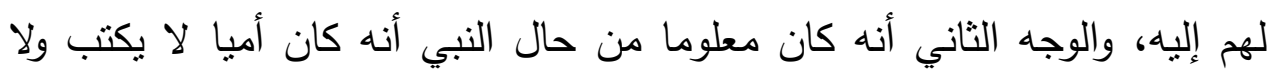

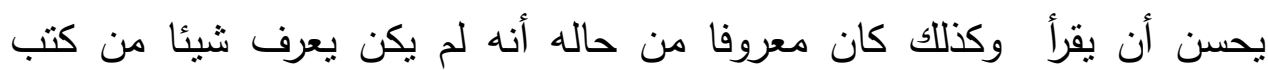

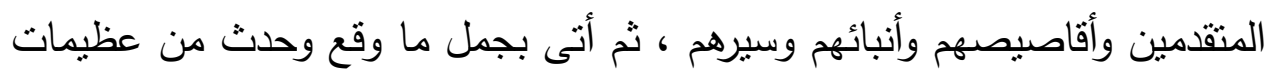

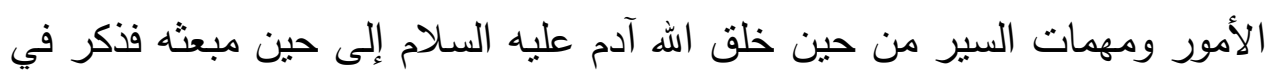
الكتاب الذي جاء به معزة له قصة آدم عليه السلام وابتداء خلقه وما صار أمره

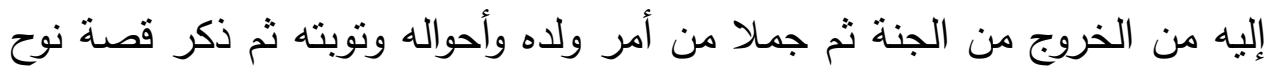
عليه السلام وما كان بينه وبين قومه وما انتهى إليه أمرهم وكذللك أمر إبراهيم عليه

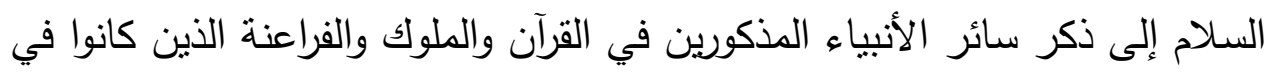

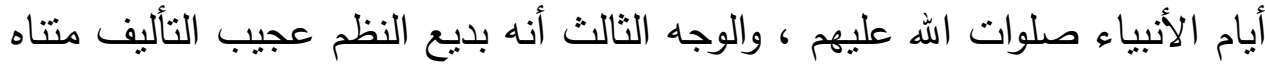

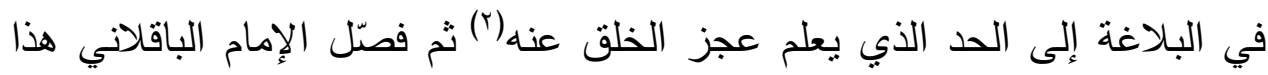

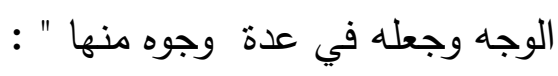

\section{فالذي يشتمل عليه بديع نظمه المتضمن للإعجاز وجوه:}

منها ما يرجع إلى الجملة وذلك أن نظم القرآن على تصرف وجوهه وتباين

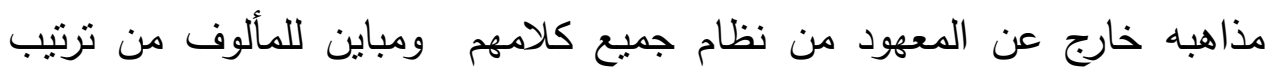

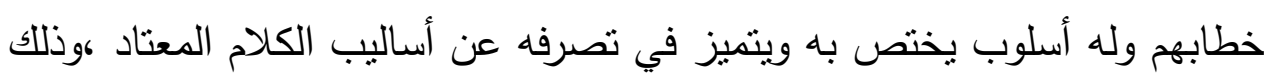

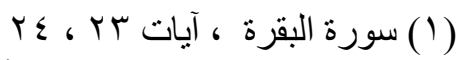

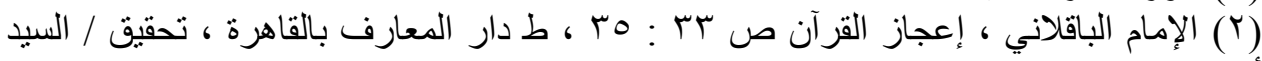
أحمد صقر.

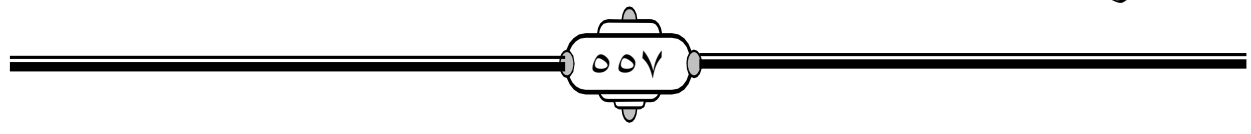




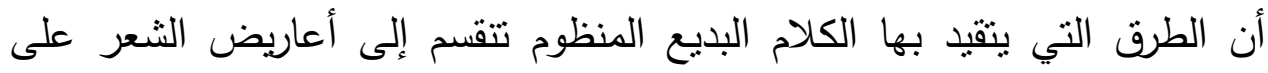

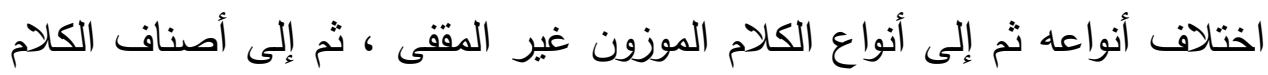

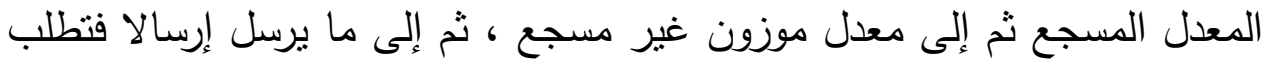

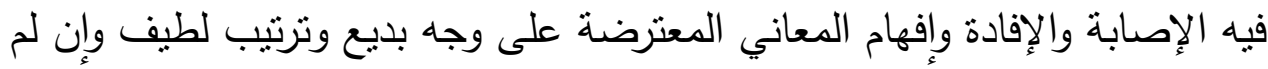

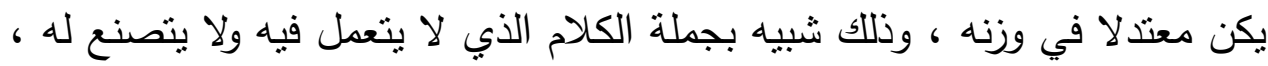

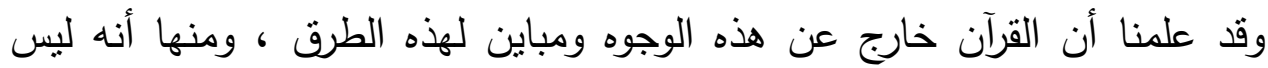
للعرب كلام مشتمل على هذه الفصاحة والغرابة والتصرف البديع والمعاني اللطيفة والفوائد الغزيرة والحكم الكثيرة والتناسب في البلاغة والتثابه في البراعة على هذا الطول وعلى هذا القدر ومنها أن عجيب نظمه وبديع نأليفه لا يتفاوت ولا يتباين على ما يتصرف إليه من الوجوه التي يتصرف فيها من ذكر قصص ومواعظ

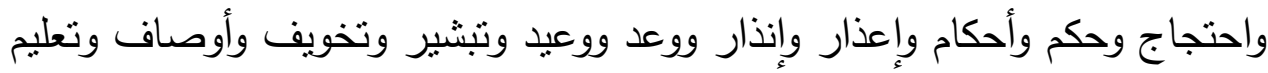
أخلاق كريمة وشيم رفيعة وسير مأثورة وغير ذلك من الوجوه التي يشتمل عليها ومنها وهو أن نظم القرآن وقع موقعا في البلاغة يخرج عن عادة كلام الجن كما يخرج عن عادة كلام الإنس فهم يعجزون عن الإتيان بمثلك كعزنا ويقصرون دونه

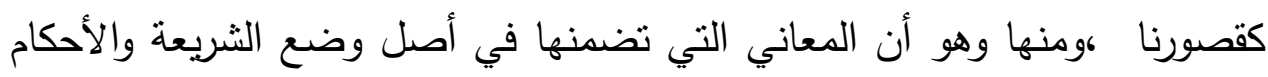

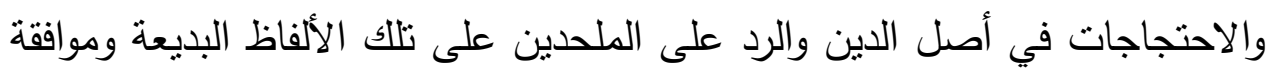
بعضها بعضا في اللطف والبراعة مما يتعذر على البشر ويمتتع وذلك أنه قد علم أن

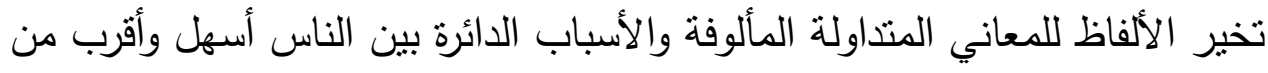

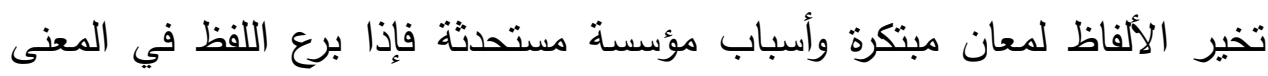
البارع كان ألطف وأعجب من أن يوجد اللفظ البارع في المعنى المتداول المتكرر

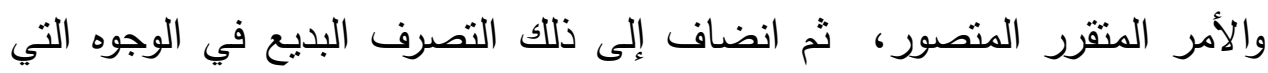



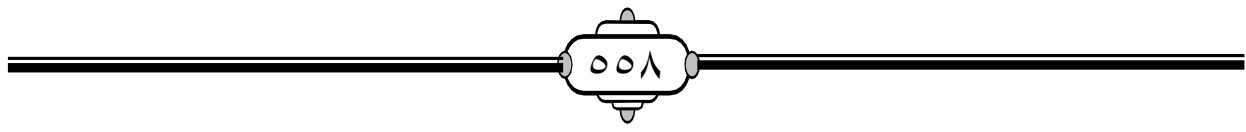


وجدت الألفاظ وفق المعنى والمعاني وفقها لا يفضل أحدهما على الآخر فالبراعة

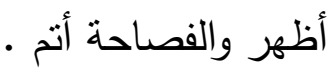

ومنها أن الكلام يتبين فضله ورجحان فصاحته بأن تذكر منه الكلمة في تضاعيف كلام أو تقذف ما بين شعر فتأخذها الأسماع وتتثوف إليها النفوس ويرى بانه وجه رونقها باديا غامرا سائر ما تقرن به كالدرة التي ترى في سللك من خرز وكالياقوتة في واسطة العقد، ومنها أنه سهل سبيله فهو خارج عن الوحشي المستكره والغريب المستتكر وعن الصنعة المتكلفة وجعله قريبا إلى الإفهام، ييادر معناه لفظه إلى القلب ويسابق المغزى منه عبارته إلى النفس، وهو مع ذلك ممتتع المطلب

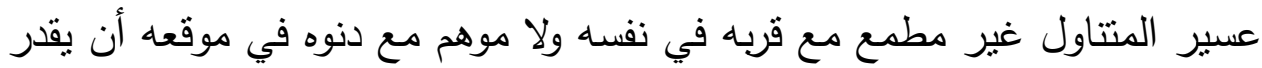

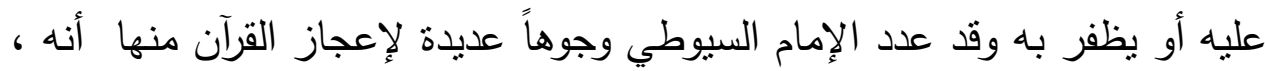
قد احتوى على علوم ومعارف لم يجمعها كتاب من الكتب، ولا أحاط بعلمها أحد في كلمات قليلة وأحرف معدودة ، ومنها كونه محفوظاً عن الزيادة والنقصان، محروسا عن التبديل والتغيير على تطاول الأزمان، بخلاف سائر الكتب ، ومنها حُسْن تأليفه، والتئام كلمه وفصاحتها، ووجوه إيجازه وبلاغته الخارقة عادةً العرب الذين هم فرسانُ النا الكلام وأربابُ هذا الثأن. ومنها مناسبة آياته وسوره وارتباط بعضها ببعض، حتى ولى التهان

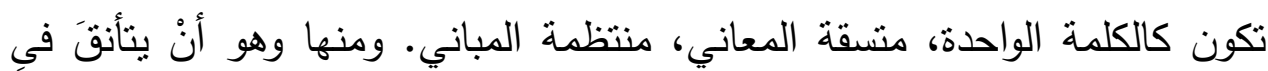

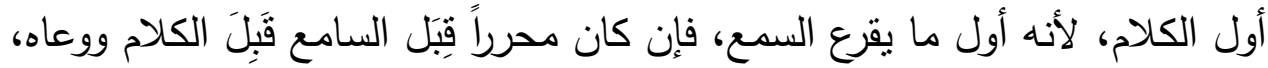
وإلا أعرض عنه، وإن كان في نهاية الحسن، منها (مُشنْنَّهات آياته) ومنها (ورود مشكله حتى يوهم التعارض بين الآيات، ومنها (وقوع ناسخه ومنسوخه) ومنها (اختلاف ألفاظه في الحروف وكيفيتها من تخفيف وتتثديد وغيرهما) ومنها تقديم بعض ألفاظه وتأخيرها في مواضع، ومنها (احتواؤه على جميع لغات العرب وبلغة غيرهم من الفرس والروم والحبثة وغيرهم)ومنها الروعة التي تلحق قلوبَ سامعيه

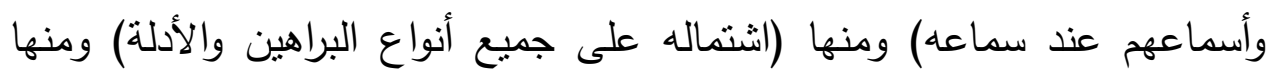

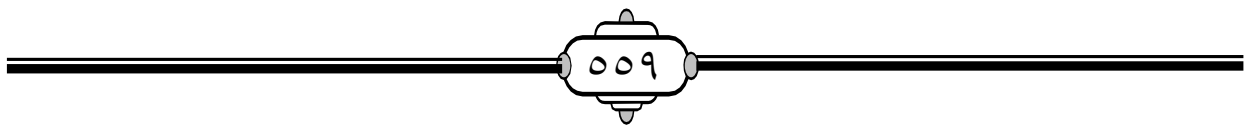


(ورود آيات مُبهمة يحيرُ العقل فيها) وغيرها من الوجوه(') وقد أبدع المفكرون والعلماء في إظهار وجوه اعجاز القرآن الكريم ، ولكن الدكتورة عائشة عبد الرحمن ( بنت الثاطئ ) ، أتت بما يفيد في هذا الموضوع فقالت : " لعل من إعجاز القرآن أن تظل الأجيال تتوارد عليه جيلا بعد جيل، وهو رحب المدى سخى المورد، كلما حسب جيل أنه بلغ منه مبلغاً، امتذ الأفق بعيدا وراء كل مطمح وفوق كل طاقة(؟) وقد ألف العلماء والمفكرون في إعجاز القرآن الكريم الكثير من الكتب والمؤلفات . أخلص مما سلف إلي أن كل نبي أيده الله بمعزة لإثبات نبوته أمام قومه، فكانت إما أن تعجزهم وتأخذ بقلوبهم وعقولهم فيؤمنوا بها ، وإما أن تعجزهم وتبهتهم لإنه فيكذبوها ويجحدوها، وبذا بستحقون عقاب الله ليَّلن ، ولذلك تتوعت المعجزات.

\section{أنواع المعجزات وطرق إثباتها :}

لقد حكى القرآن الكريم وقص علينا في قصص الأنبياء بعض آياتهم المعجزة من الأحداث الكونية التي وقعت علي أيديهر مما جرى مجرى التشريف والتكريم كانشقاق القمر، ومما تحدوا به أقوامهم مما لا يمكن أن يدخل تحت سنة من سنن الحياة المعروفة للعقول كالقرآن الكريم وعصا موسى عليه السلام، لقد سمى القرآن الكريم بعض تلاك الآيات الكونية براهين ،لأنها دليل علي صدق من أجراها الله علي يده وأذن في التحدي بها كما يبينه قول الله تعالي بعد أن ذكر آية سيدنا موسى بهى



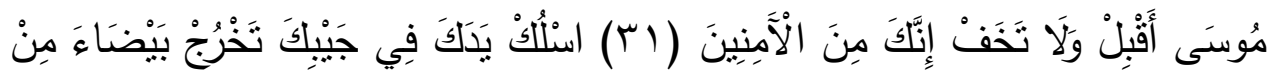

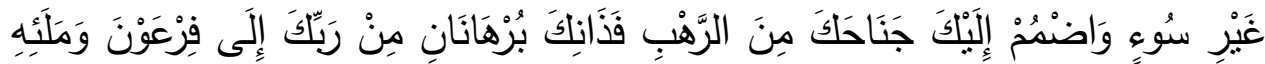

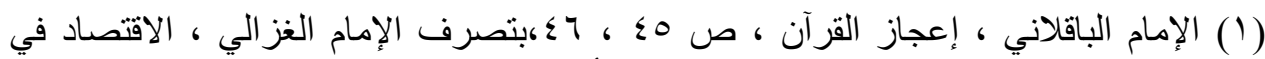

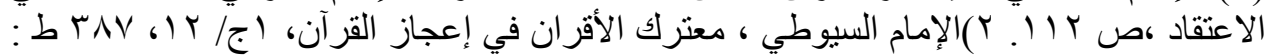

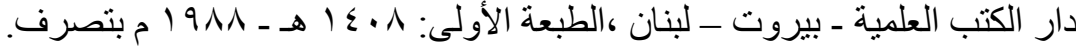

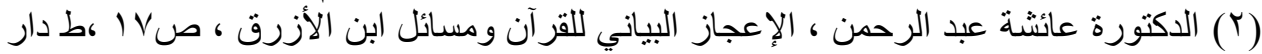

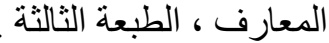


إِنَّهُْ كَانُوا قَوْمًا فَاسِقِينَ )(') فانقلاب عصا موسى حية تسعى ،وإخراج يده بيضاء من غير سوء ، وانفلاق البحر لله ولقومه ، ونتق الجبل فوقهم كالظلة ، وإحياء عيسى للموتى وإبراؤه للأكمه والأبرص وخلقه من غير أب ،وعدم إحراق النار لإبراهيم عليه السلام ،وسائر آيات الأنبياء في قصصهم التي لا تحتمل تمحلا ولا تأويلا كل ذلك من المعجزات والخوارق التي وقعت فعلا وشاهدها الوجود ، ولذلك ت ت توعت المعجزات

أنواع المعجزات: ذهب العلماء إلي أنَّ المعجزات تدور في أنواع عدة ، وذلك . يرجع إلي تفاوت الناس في القبول والعقول ، يقول الإمام الآمدي :" إن قيل: إنما جاز نصب الأدلة العقلية، و إظهار المعجزات المتعددة الدالة على صدق الرسول؛ لأن الناس يتفاوتون فى دلالة الأدلة العقلية ، ودلالة المعجزات على الصدق؛ لتفاوت الأدلة، والمعجزات فى الظهور والخفاء بالنسبة إلي نظر الناس، حتى إنه يسهل على بعض الناس النظر فى بعض الأدلة دون البعض. و كذلك فى في إلى

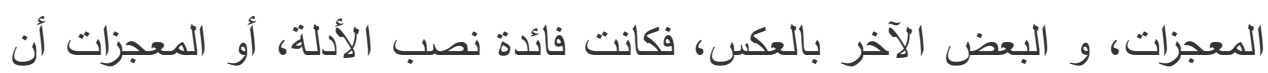

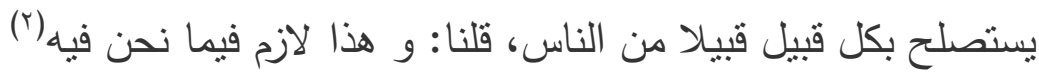
والمعجزات منها العقلية المعنوية، ومنها المادية الحسية ، وسنفصل الأمر في ذللك ويتبين لنا ذلك من الإمام الغزالي عند حديثه عن إثبات نبوة سيدنا محمد صلى الله عليه وسلم فقال : "وفي إثبات نبوته بالمعجزة طريقتان: الطريقة الأولى: التمسك بالقرآن، فإنا نقول: لا معنى للمعجزة إلا ما يقترن بتحدي النبي عند استشهاده على صدقه على وجه يعجز الخلق عن معارضته، 


\section{علاقة معجزات الأنبياء بالتقاسم الحضاري}

وتحديه على العرب مع شغفهم بالفصاحة وإغراقهم فيها منواتر ، وعدم المعارضة معلوم، إذ لو كان لظهر ـ

الطريقة الثانية: أن تتبت نبوته بجملة من الأفعال الخارقة للعادات التي ظهرت عليه، كانشقاق القمر، ونطق العجماء، وتفجر الماء من بين أصابعه، وتسبيح الحصى في كفه، وتكثير الطعام القليل، وغيره من خوارق العادات، وكل ذلك دليل على صدقه(') ومن هنا أخذ العلماء في ثقسيم المعززات إلي عقلية معنوية ، وإلي وني

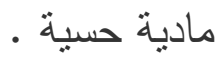

\section{النوع الأول : المعجزات العقليَّة المعنوية :}

وهي معجزة وحيدة ، وهي القرآن الكريم ، وهو ما يؤكّد هـ علماء الأصول أنها

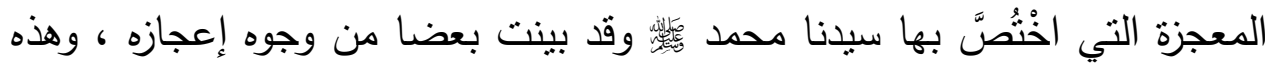
المعجزة طريق ثبوتها التواتز وهي معجزة للتحدي • وإضافة إلى هذه المعجزة الكبرى فإن الله تعالي أكرم نبيَّه بآيات كونيَّة جمة، وخوارق ومعجزات حسيَّة عديدة، ولكن لم يقصد بها التحدي، أي إقامة الحجة بها بهاب على صدق نبوته ورسالته ، بل كانت تكريمًا من الله تعالى له و رحمة وكرامة من الله لرسوله والمؤمنين (r) مما سنبينه بعد ذلك.

\section{النوع الثاني: المعجزات المادية الحسيَّة: وتتتوع إلي :}

أ ) معجزات مادية حسية غير متكررة: وهذه المعجزات بدركها الناس بحواسهم، كما يدركون اللون الأبيض والأسود، وغالبا ما تكون مقرونة بزمنٍ معين، ولأناس معينين وهم الذين يحضرونها ويشاهدونها، فتكون حجة عليهم، وأما الذين لم

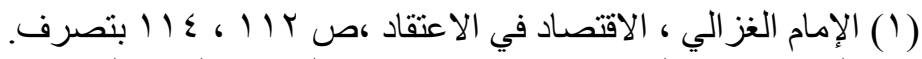

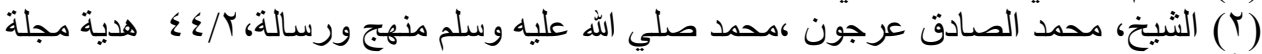


يحضروها ولم يثاهدوها لغيابهم فتكون حجة عليهم بتواتز أخبارها إليهم، وهذه المعزات تحدث مرة واحدة للنبي ولا تتكرر له، منل انحباس الثمس ليوشع بن نون عليه السلام ، وانفلاق الجبل عن ناقة لسيدنا صالح عليه السلام . ب) معجزات مادية حسية متكرة : وهي التي يتكرر حدوثها على يد النبي

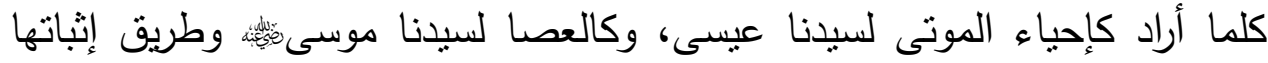
المشاهدة للحاضرين، والتواتر لمن لم يحضر وهو ما سأبينه بالتفصيل. ج) معجزات مادية غيبية : وهي ما يخبر به النبي عن الغيب في الماضي أو الحاضر أو المستقبل ، وهذه تحدث وتتقرض سواء في حياة النبي أو بعد موته ، كالتي أعطيت لسيدنا يوسف عليه السلام ، قال تعالى على لسانه: [قَالَ لَا يَأْنِكُمَا

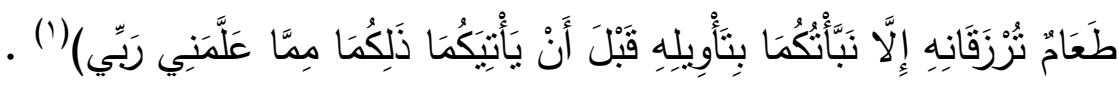
وكالتي أعطيت لسيدنا عيسى عليه السلام قال تعالى على لسانه في معرض

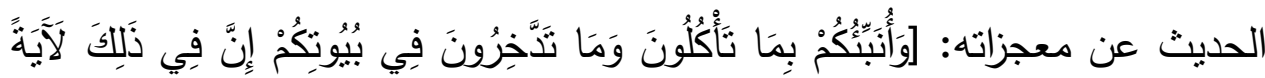

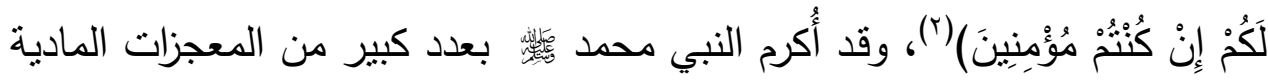
الغيبية، كإخباره وتبشيره بفتح الثام وفارس ومصر ، وهو ما وقع بعد موته، وبعث المهدي وخروج الاجال ونزول عيسى وهو ما سيقع في المستقبل، وما حدث منها وإن لم نعاصره وما سيحدث منها وإن لم نشاهده لموتتا ،فإنه حجة علينا لأنه ثابت بالقرآن ، أو بالسنة ، أو بالإجماع . لماهن كما أن هذه المعجزات الحسية تنقسم من حيث النوع إلي : أ) معجزات حسية نبانية كعصا سيدنا موسى عليه السلام ، وكحنين الجذع لسيدنا محمد صلى الله عليه وسلم • لبه

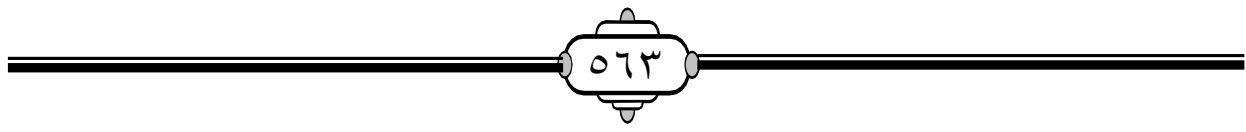




\section{علاقة معجزات الأنبياء بالتقاسم الحضاري}

ب) معجزات حسية جمادية كتسبيح الحصى في كف سيدنا محمد صلى الله

عليه وسلم.

ج) معجزات حسية حيوانية كناقة سيدنا صالح عليه السلام ، ونطق الثاة المسمومة لسيدنا محمد صلى الله عليه وسلم.

د) معجزات متغيرة كعصا سيدنا موسى عليه السلام التي تحولت من نباتية إلي حيوانية مرة (حية تسعى ) وجمادية مرة أخرى حين ضرب بها الحجر وضرب ميرب

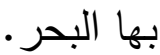

هـ معجزات حسية كونية ،كانشقاق القمر لسيدنا محمد صلى الله عليه وسلم ، ونبع الماء من بين أصابعه، وانحباس الثمس لسيدنا يوشع بن نون عليه السلام. و) معجزات حسية طبية ، كإحياء الموتى لسيدنا عيسى عليه السلام ، ورد عين قتادة لسيدنا محمد صلى الله عليه وسلم وهكذا نتتوع المعجزات .

نخلص من ذلك: أن المعجزات المادية الحسية غير المتكررة ينتهي فعلها خلال حياة النبي، وأما المتكررة فينتهي بموته، وأما ذكرها فيستمر بتواتر أخبارها ، وينقطع بانقطاع أخبارها، لكن يبقي الاعتقاد بمعزات الأنبياء والتصديق بها قائما. والمعزات السابقة معجزات مادية حسية صرفة ،فالمعزات الحسية كانت قوية لمن رآها وشهدها، ولكنها تبقى عرضة للثك لمن سمعها جيلًا بعد جيل. وإيمان المؤمنين بمعجزات الأنبياء السابقين إنما كان لإخبار القرآن الكريم والسنة النبوية بها أما معجزة القرآن الكريم فباقية يقول الإمام الشعراوي "إن معجزة سيدنا محمد باقية بقاء أبديا ومتصلة به أبدا ، أما معجزة كل رسول سبق رسول الهه فقد أدت مهيتها لمن رآها وانتهت ، وانفصلت معجزة كل رسول سابق علي رسول عن منهجه، لأن سيدنا موسى عليه السلام منهجه التوراة ومعجزته العصا ، وسيدنا عيسى عليه السلام منهجه الإنجيل ومعجزته إبراء الأكمه والأبرص ، أما سيدنا محمد صلى الله $=\overbrace{07 \varepsilon}^{075}=$ 
عليه وسلم فمنهجه معجزته ، لتكون المعجزة دليلا علي صدق المنهج في أي وقت " .. ثم يقول : " إن آيات اله الكونية التي لا تتأثز فأي فائدة للإنسان إن عرفها أو لم يعرفها فقد طمرها اله وسترها في القرآن الكريم وأثنار إليها ، لأن العقل المعاصر لنزول القرآن الكريم لم يكن قادرا علي استيعابها في زمن الرسالة ، ومن رحمة الله

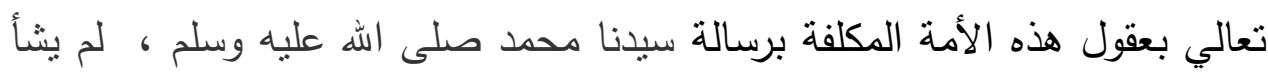
أن يجعل نواميسه في الكون واضحة وصريحة حتى لا تقف العقول فيها وتعجز عن فهمها .... لذلك فالقرآن الكريم كتاب منهج ، والمعجزة أمر جاء لتأييد المنهج ،فلم يثأ أن يجعل من المعجزة ما يعوق عن المنهج ، لكنه ترك في الكون طموحات للعقل المخلوق لله تعالي والمادة الكونية المخلوقة لهه تعالي ، وكل يوم يكتشف العقل البشري أشياء ، وهذا الاكتشاف لا يأتي من فراغ ، بل من أشياء موجودة(') . إذن العقل البشري مجرد مكتشف لما خفي فقط وليس مبتكراً ، ولذلك قال الله تعالي ( سنريهم آياتتا في الآفاق وفي أنفسهم حتى يتبين لهم أنه الحق)(؟) .

\section{فوائد المعجزات :}

إن تأييد الله لأنبيائه بالمعجزات فيها كثير من الفوائد منها أنها:

بيان لقرة اله تعالي، وتصديق وبرهان علي نبوتهم ،وحجة علي مكذبيهم ، وليس ذللك فحسب ، وإنما هنالك فوائد جليلة وعظيمة للمعزات أيضا غير التحدي والإعجاز ومن هذه الفوائد والتي تجمع بين أمرين في النبوات : الأمر الأول : أن من فوائد بعثة الرسل تعليم الناس الصناعات الضرورية النافعة لأمر المعاش، مثل صناعة الدروع التي تعلمها الناس من سيدنا داود عليه

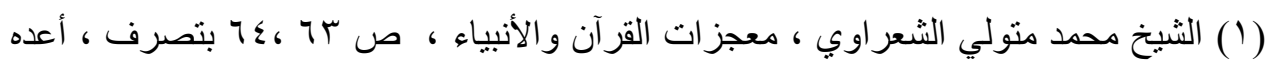

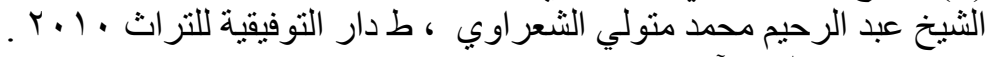

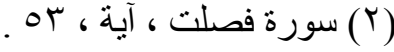


السلام التي تلبس في الحرب لتحفظ الناس ، كذلك صناعة السفن من سيدنا نوح عليه السلام وما فيها من منافع ، وحياكة الملابس والغزل والنسيج والبناء كلها تعلمها الناس من الأنبياء ، يقول الإمام الرازي والإمام البيضاوي بعد أن عدد الكثير

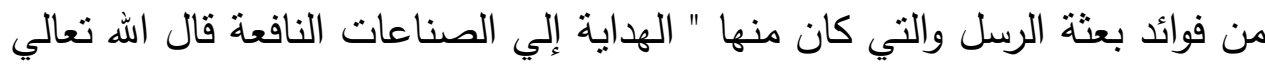
في داود عليه الصلاة والسلام " وعلمناه صنعة لبوس لكم "(') وقال لنوح عليه السلام " واصنع الفلك بأعيننا "(r) ولا شك أن الحاجة إلي الغزل والخياطة والبناء وما يجري مجراها أثند من الحاجة إلي الدرع وتوقيفها علي استخراجها بالتجربة خطر

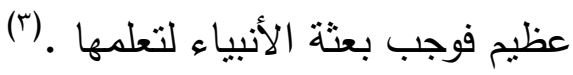
الأمر الثاني : لتظل تلك المعجزات نبراسا ورمزا وعلامة للناس علي مر الأزمان حتى بعد وفاة الأنبياء الذين ظهرت علي أيديهم تلك المعجزات ما دام القرآن يتلي ، لأنها مذكورة فيه يتعلم الناس منها وبطوروا فيها باستخدام الوسائل الحديثة. فقد بين القرآن الكربم أن الأنبياء عليهم السلام قد بعثوا إلى مجتمعات إنسانية

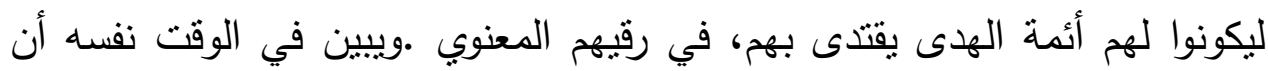
الله قد وضع بيد كلٍ منهم معجزة مادية، ونصبهم رواداً للبشرية وأساتذة لها في تقدمها المادي أيضاً ، أي أنه يأمر بالاقتداء بهم واتباعهم اتباعاً كاملاً في الأمور المادية والمعنوية؛ كما يحض القرآنُ الكريم الإنسانَ على الاستزادة من نور الخصال الحميدة التي يتحلى بها الأنبياء عليهم السلام، وذللك عند بحثه عن كمالاتهم المعنوية فإنه عند بحثه عن معجزاتهم المادية أيضاً يومئ إلى إثارة شوق الإنسان ليقوم بتقليد تلك المعجزات التي في أيديهم، ويثير إلى حضهه على بلوغ نظائرها،

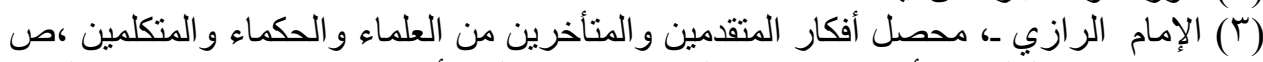

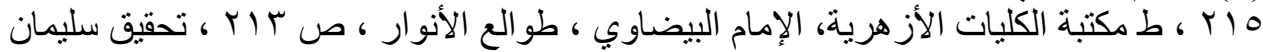

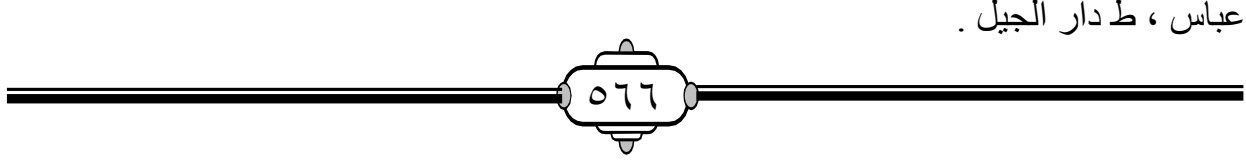


أما الإمام محمد عبده فله رأي آخر في معجزات الأنبياء فيقول : " ليس من وظائف الرسل ما هو عمل المدرسين ومعلمي الصناعات ، فليس مما جاعوا له تعليم التاريخ ولا تقصيل ما يحويه عالم الكواكب ولا بيان ما اختلف من حركاتها وغير ذلك مما وضعت له تلك العلوم وتسابقت في الوصول إلي دقائقه الفهوم •

فإن ذللك كله من وسائل الكسب وتحصيل طرق الراحة ، هدى الله إلبه البشر بما أودع فيهم من الإدراك ، يزيد من سعادة المحصلين، ويقضي فيه بالنكد علي المقصرين ، ولكن كانت سنة الله في ذلك أن يتبع طريقة التدرج في الكمال ، وقد جاءت شرائع الأنبياء بما يحمل علي الإجمال بالسعي فيه ، وما يكفل التزامه الوصول إلي ما أعد الله له الفطر الإنسانية من مراتب الارتقاء ، وأما ما ورد في الإهي كلام الأنبياء من الإثارة إلي شئ من ذلك ، فإنما يقصد منه النظر إلي ما فيه من الدلالة علي حكمة مبدعه ، أو توجيه الفكر إلي الغوص لإدراك أسراره وبدائعه('). لكني أؤيد الرأي القائل أن المعجزة وهي من أقوال الهه تعالي وأفعاله التي أهدت الى البشرية الكمال المادي وخوارقه لأول مرة، مثلما أهدت إليها الكمال المعنوي . فدونك سفينة نوح عليه السلام وهي إحدى معجزاته ،وعصا سيدنا موسى عليه

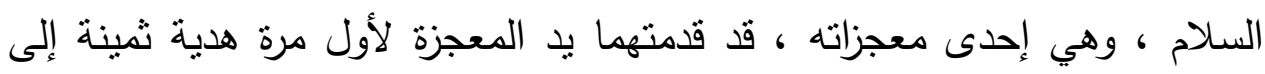

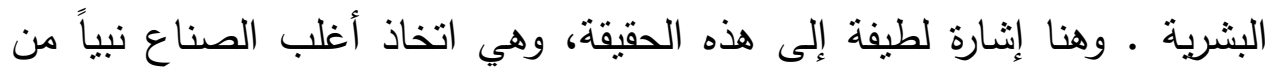
الأنبياء رائداً لصنعتهم وقطباً لمهنتهم. فالملاحون - مثناً - اتخذوا سيدنا نوحاً عليه السلام رائدهم، والخياطون اتخذوا سيدنا إدريس عليه السلام مرشدهم. ولما كان العلماء المحققون من أهل البلاغة قد اتفقوا جميعاً أن لكل آية كريمة وجوهاً عدة للإرشاد، وجهات كثيرة للهداية، فلا بمكن إذاً أن تكون أسطع الآيات

(1) الإمام محمد عبده ، رسالة التوحيد ، ص سب ا ، ط الهيئة العامة لقصور الثقافة. 
وهي آيات المعجزات، سرداً تاريخياً، بل لابد أن تتضمن أيضاً معاني بليغة جمة

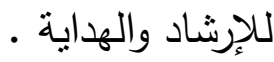

نعم، إن القرآن الكريم بإيراده معززات الأنبياء، إنما يخط الحدود النهائية

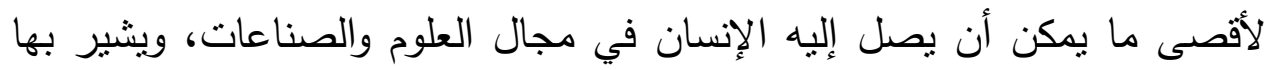
إلى أبعد نهاياتها، وغاية ما يمكن أن تحققه البشرية من أهداف، فهو بهذا بعين أبعد الإندان

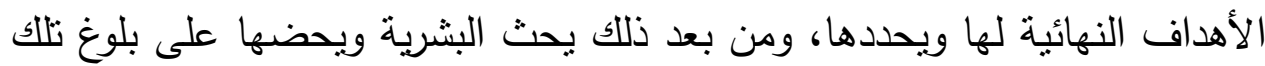
الغاية، ويسوقها إليها ، إذ كما أن الماضي مستودع بذور المستقبل ومرآة تعكس لإنس

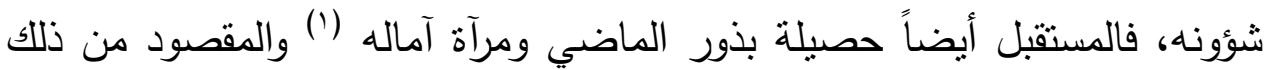
الاعتقاد الديني والتصديق القلبي، وهذا إن دل علي شئ فإنما يدل علي مقصد ( النورسي ) في أثز الإيمان بالمعزات علي السلوك البشري وكيفية تقويمه وتهذيبه ،والإيمان بالوحي الإلهي مصدر النبوة والمعجزات الغيبية و الاعتقاد في هذا الثأن واضح وصريح ،وذللك من خلال الحاصل والواقع عبر التاريخ الاستقرائي ،وما ثبت التب من عجز العقل البشري عن التحدي أمام الأمور الغيبية ، هذا من ناحية ،ومن ناحية أخرى ، يجزم الاعتقاد بأن ما يحدث للأنبياء ويخص شئونهم في الأوامر والنواهي الإلهية ،أو فيما بسمو علي العقل البشري إنما يكون بفعل الوحي الإلهي

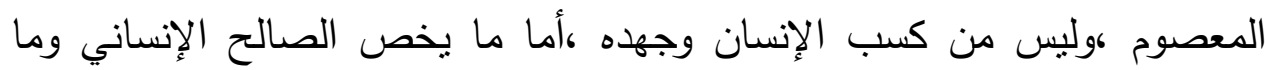

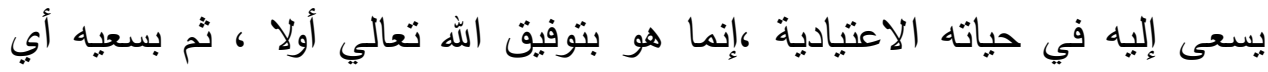

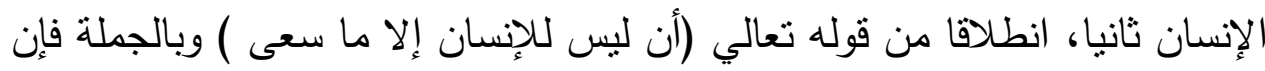

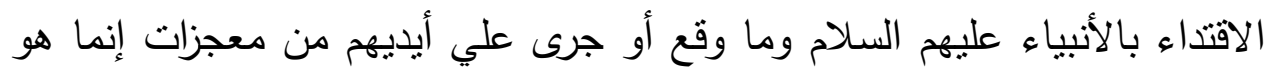

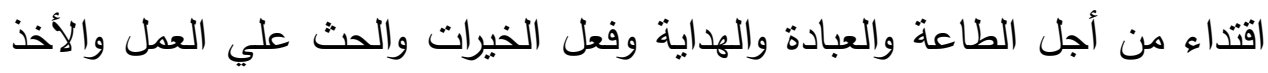

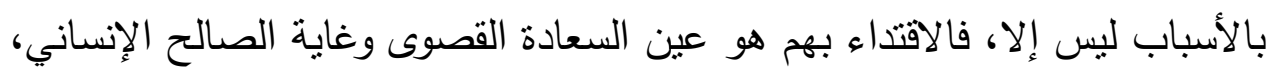

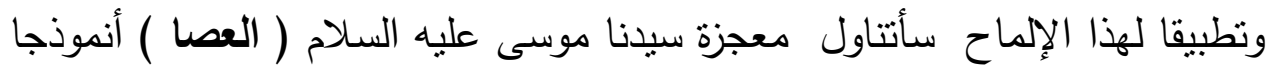

(1 (الثيخ سعيد النورسي ، كليات رسائل النور ، الكلمات ص ^بr وما بعدها ، بتصرف. 
لإقامة حضارة وكيف كانت علامة وإنشارة ورمزا لذلك ، وسأتتاولها في حياته

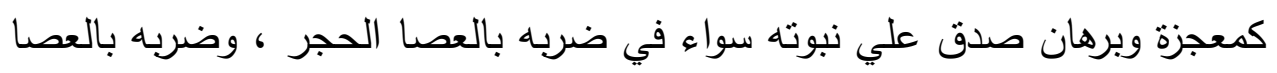

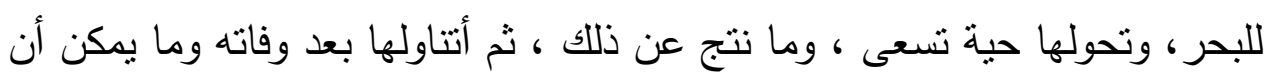

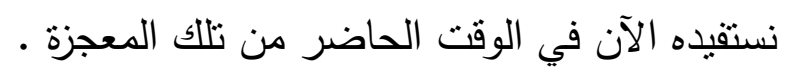




\section{الفصل الثالث \\ الجانب التطبيقي}

اـ العصا في زمن سيدنا موسى عليه السلام ولها مراحل:

المرحلت الأولى : قلبها حيتّ تشعى.

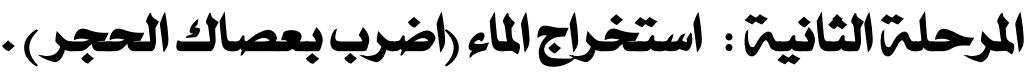

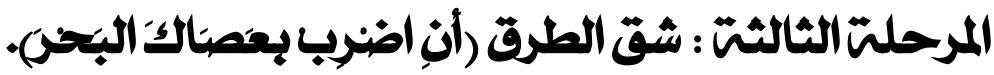

المرحلتّالرابعتّ : بعد زمن سيدنا موسى عليه السلام.

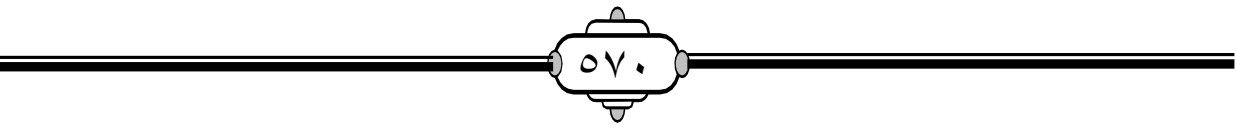




\section{الفصل الثالث}

\section{الجاتب التطبيقي}

أيد الهه تعالي سيدنا موسى عليه السلام بالكثير من المعجزات والآيات البينات كوذلك لكثرة عناد وتكبر واستعلاء فرعون وملأه، وقد بين الله سبحانه وتعالى ذلك

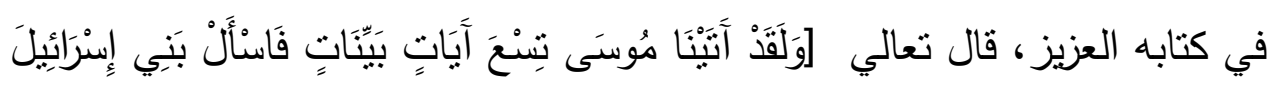

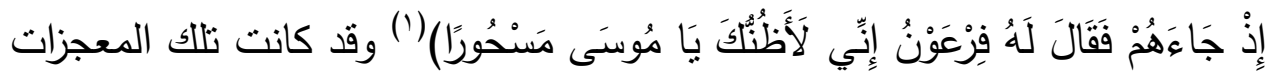
إما بين سيدنا موسى عليه السلام وفرعون ، أو بين سيدنا موسى عليه السلام وقومه، ويوضح الإمام الرازي ذلك فيقول :

"اعلم أنه تعالى ذكر في القرآن الكريم أثياء كثثرة من معجزات موسى عليه السلام أحدها : أن الهه تعالى أزال العقدة من لسانه قيل في التفسير ذهبت العجمة وصار فصيحاً، وثانيها : انقلاب العصا حية. وثالثها : ثلقف الحية حبالهم وعصيهم مع كثرتها، ورابعها : اليد البيضاء وخمسة أخر وهي الطوفان والجراد والقمل والتها

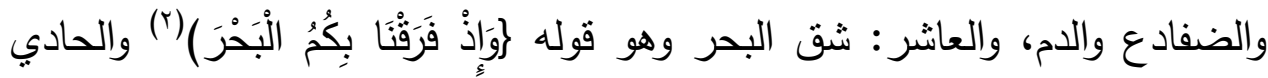

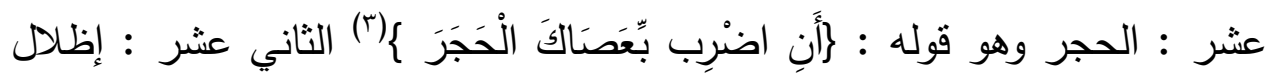

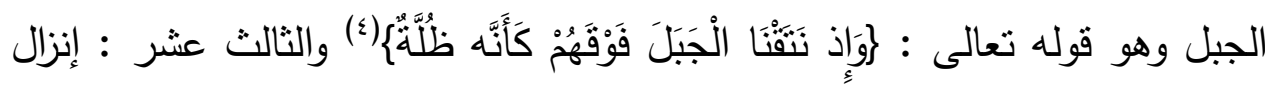
المن والسلوى عليه وعلى قومه، والرابع عشر والخامس عشر قوله تعالى: ـروَلَََّْ

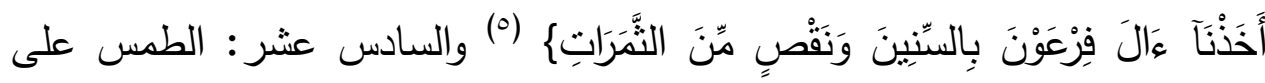

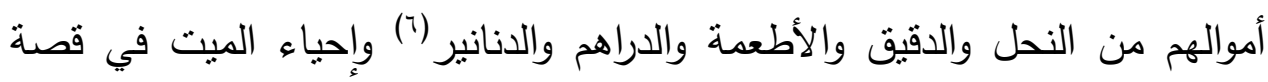

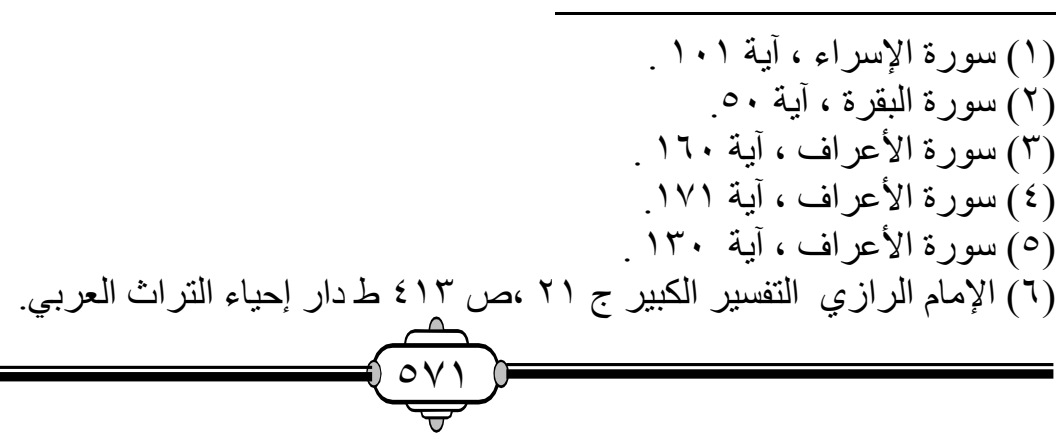




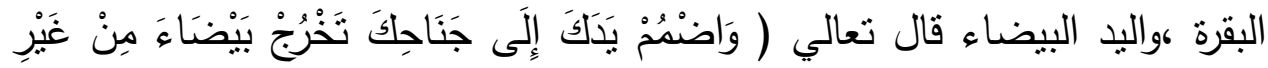
سُوٍٍْ آَيَةً أُخْرَى)(') وهي معجزات حسية تخاطب الحواس، ولعل السبب في ذلك يرجع إلي الرباط الوثيق بين الناس والطبيعة من جهةٍ وبين سبطرة المادة والعلوم المادية عليهر من جهةٍ أخرى ، ولذلك كان يؤثز فيهم المعجزات التي تخرق النواميس الطبيعية وتعجز عنها علومهم المادية كقلب العصا حية وغيرها . " فالله عز وجل أعطى سيدنا موسى عليه السلام تسع آيات ، العصا واليد والدم والطوفان والجراد والقمل والضفادع والطمس والبحر، فأما العصا فكانت حجته على على الملحدين والسحرة جميعاً فلما انقلبت عصاه - وكان السحر في ذلك الوقت فاشياًحية تسعى وتلقفت حبال السحرة وعصيهم علموا أن حركتها عن حياة حادثة فيها بالحقيقة وليست من جنس ما يتخيل بالحيل ، فمع ذلك للالالة على الصانع وعلى نبوته جميعاُ ، وأما سائر الآيات التي لم يحتج إليها مع السحرة فكانت دلالته على بلى بلى فرعون وقومه القائلين بالدهر فأظهر الله بها صحة ما أخبرهم به موسى من أن له له

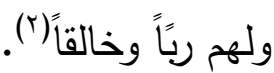
والحديث يقتصر علي معجزة العصا سواء في تحولها إلي ثعبان مبين ، وضرب الحجر بها وضرب البحر وانفلاقه ، وهذه المعجزة لسيدنا موسي عليه السلام من المعجزات التي وقعت بها الغلبة والتحدي لسيدنا موسي عليه السلام . وقد وردت قصتها في كثير من سور القرآن الكريم منها قوله تعالي: ( وَمَا تِلْكَكَ

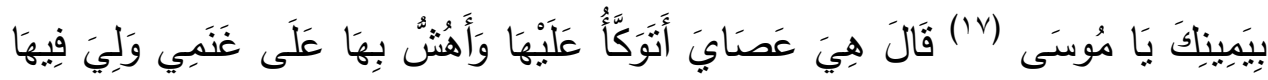
(Y) الإمام البيهقي ، دلائل النبوة ،ص ^ 1 ،9 ، ، تحقيق عبد المعطي قلعجي ، ط دار الكتب العلمية 


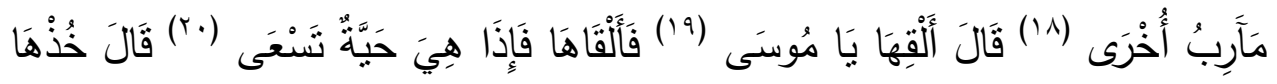

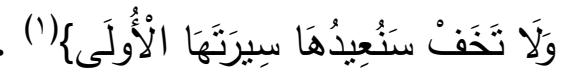

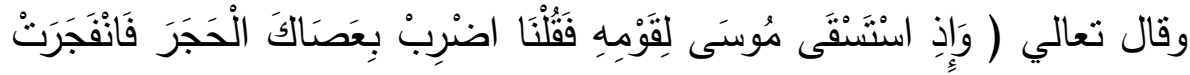

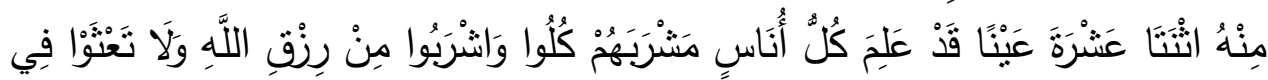

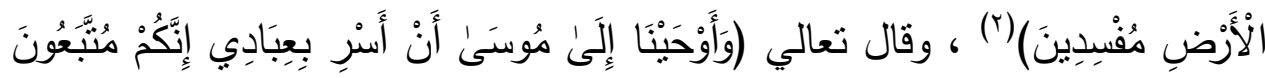

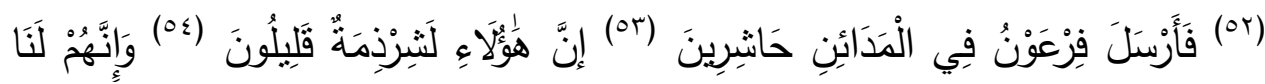

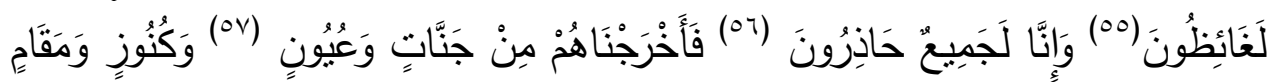

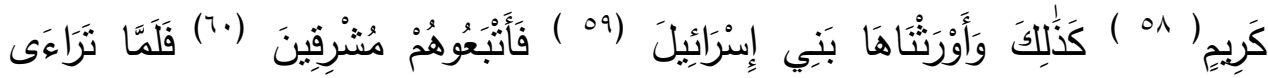

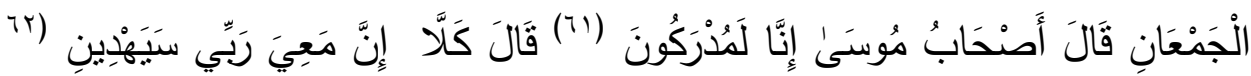

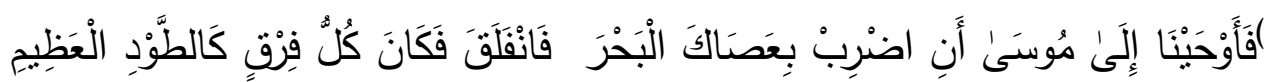

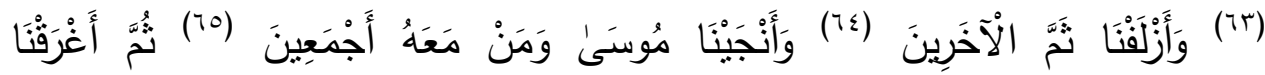

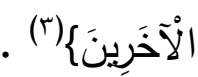

وهي من المعجزات المادية الحسية المتكررة، ومن أبرز وأظهر ما أيَّّ الله به نبيه موسى عليه السلام من المعجزات التي تحدى بها فرعون • وقد قيل في وصفها وفوائدها الكثير ، واختلفوا في العصا فقيل "العصا عشرة أذرع على طول موسى عليه السلام من آس الجنة ولها شعبنان تتقدان في الظلمة." وقال الحسن : كانت عصا أخذها من بعض الأشجار ، وقيل :كانت من آس الجنة طولها عشرة أذرع على طول موسى عليه السلام ولها شعبنان تتقدان في الظلمة

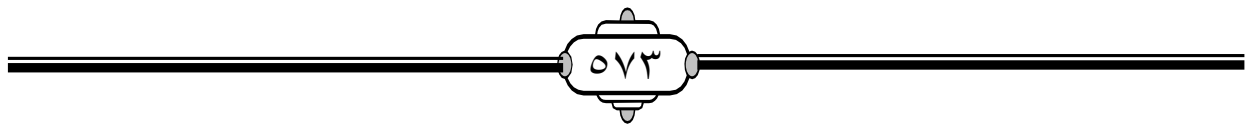


والذي يدل عليه القرآن الكريم أن مقدارها كان مقداراً يصح أن ينوكأ عليها وأن

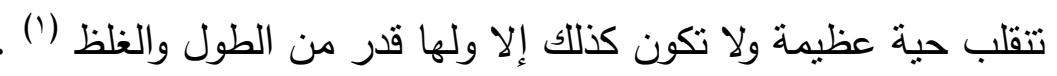
" وللعصا فوائد كثيرة : منها ما هو مذكور في القرآن الكريم علي لسان سيدنا

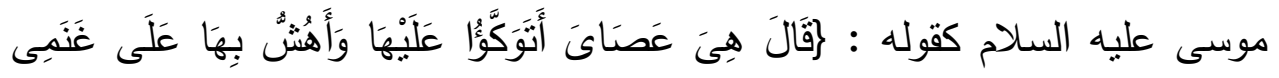

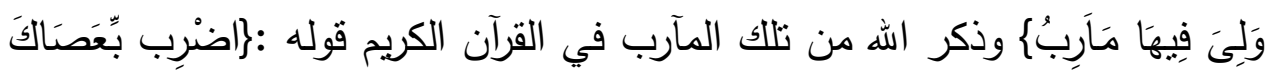

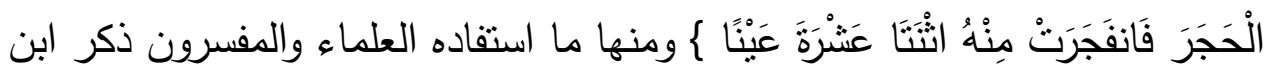

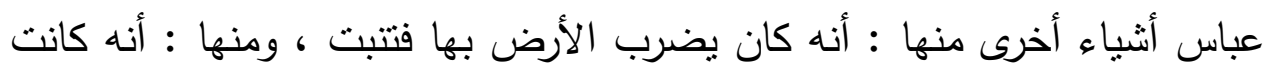

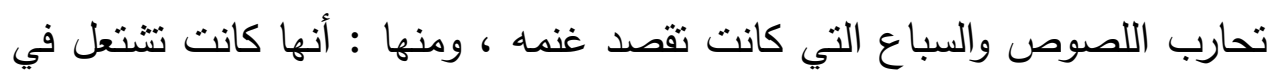

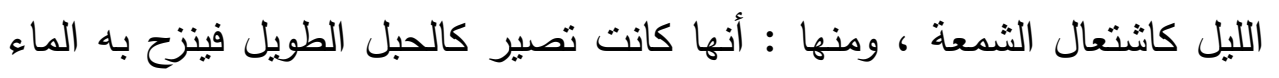

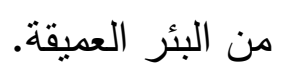

واعلم أن الفوائد المذكورة في القرآن الكريم معلومة ، فأما الأمور التي هي غير

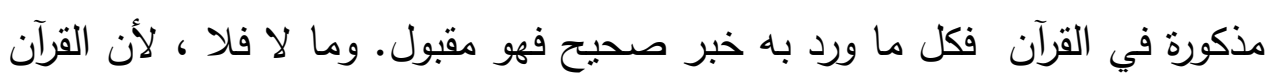

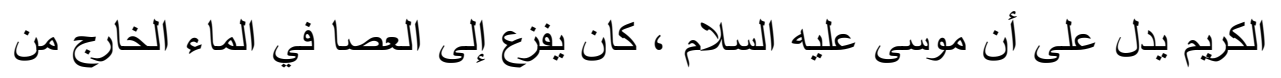

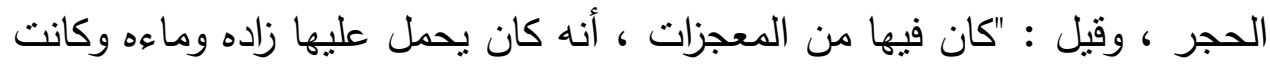

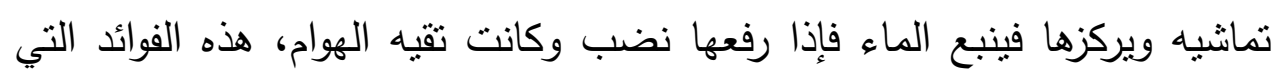

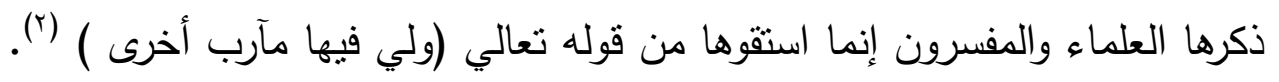
هذا ما استتبطه العلماء والمفسرون ،وللعصا أكثر من وجه في الإعجاز منها : 1- الإعجاز في قلبها حية تسعى :

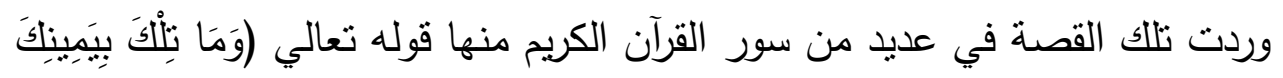

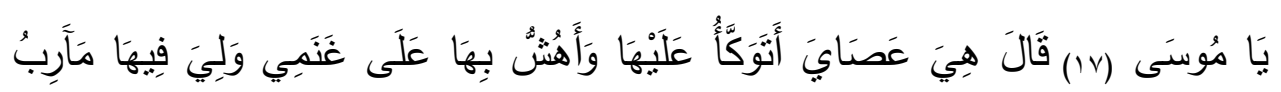

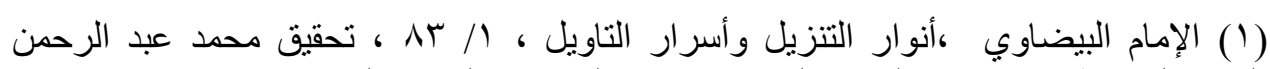

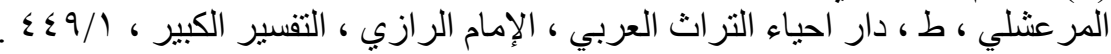

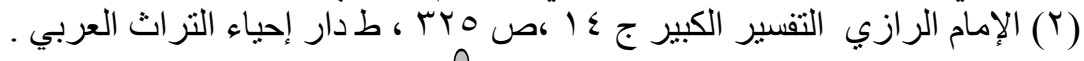
Orर 


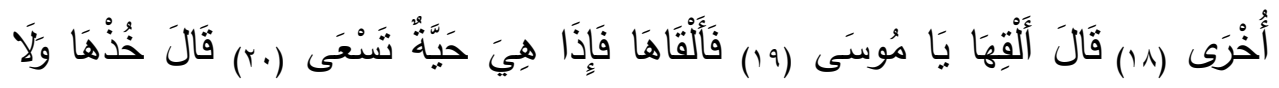

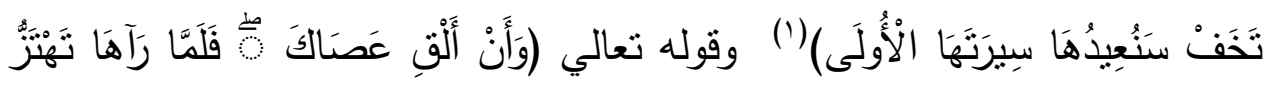

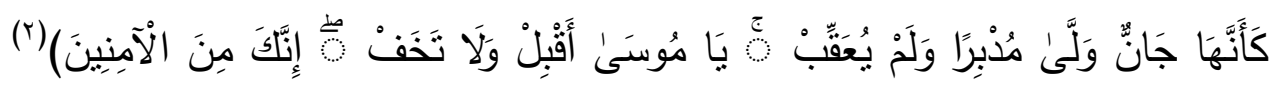

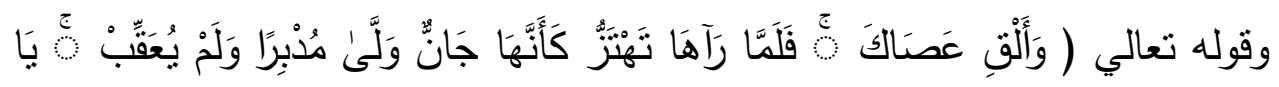

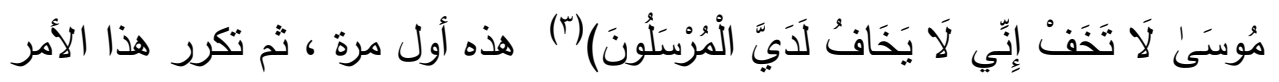

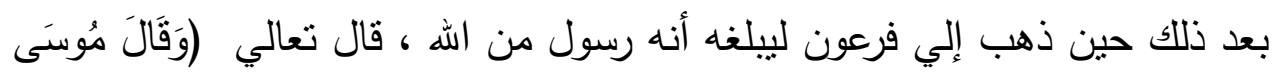

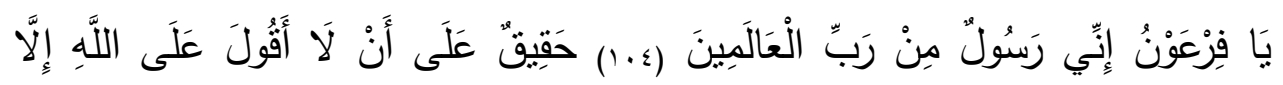

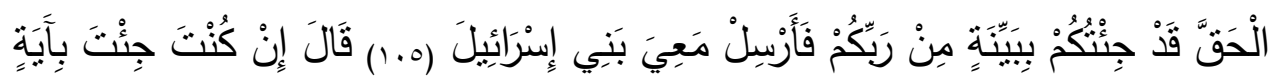

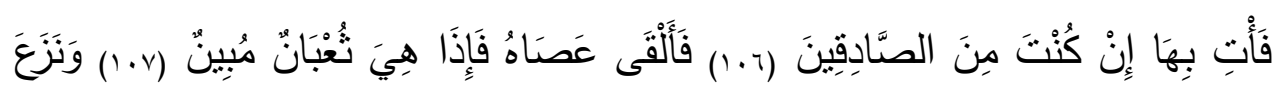

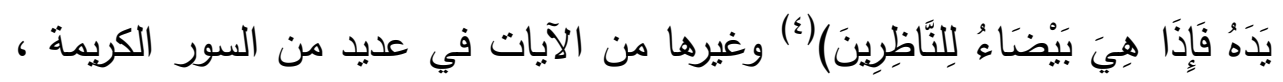

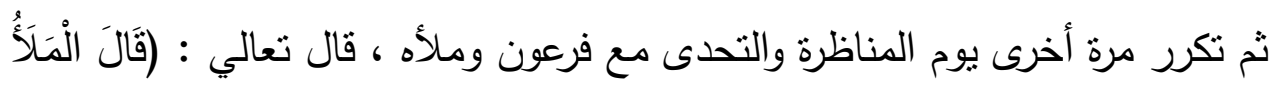

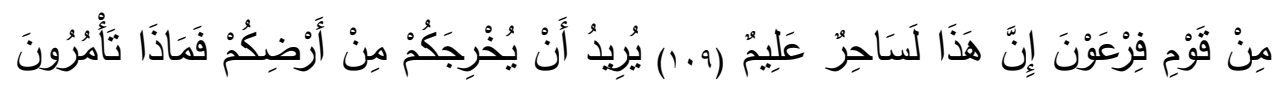

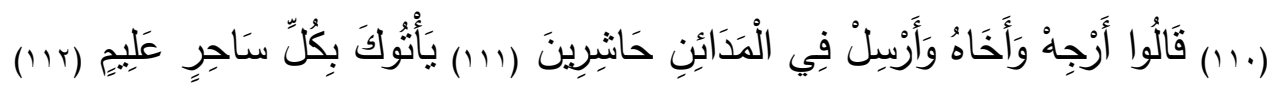

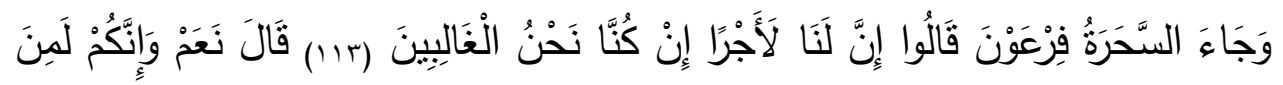

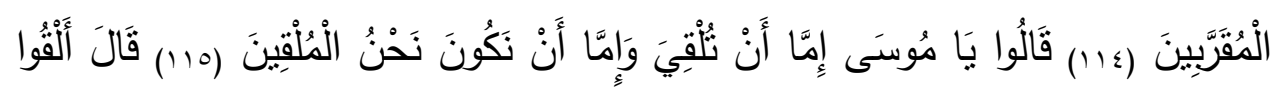

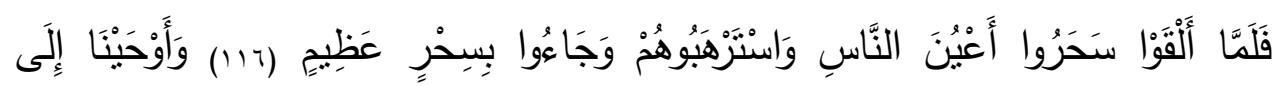

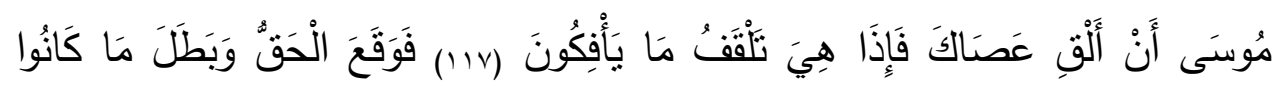

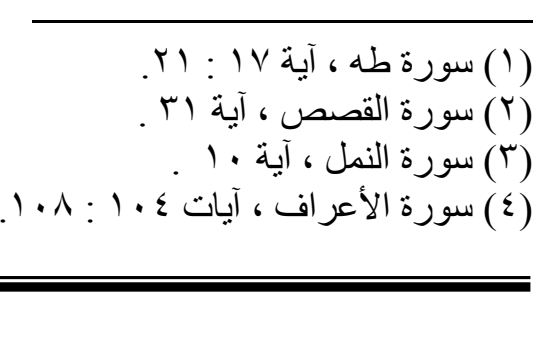




\section{علاقة معجزات الأنبياء بالتقاسم الحضاري}

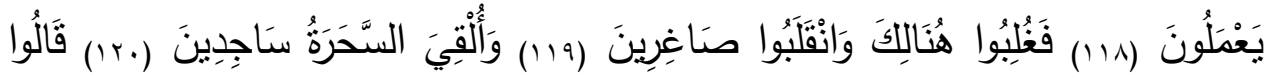

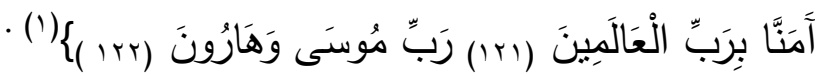

$$
\text { ولكن ما الحكمة في قلب العصا حية في ذلك الوقت ؟ }
$$

ويجيب عن ذلك الإمام الرازي فيقول : الجواب فيه وجوه : أحدها : أنه تعالى قلبها حية لتكون معجزة لموسى عليه السلام يعرف بها نبوة نفسه وذلك لأنه عليه

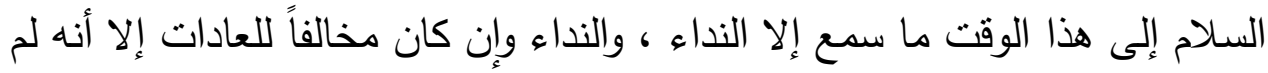
يكن معجزاً لاحتمال أن يكون ذلك من عادات الملائكة أو الجن فلا جرم قلب اله اله العصا حية ليصبر ذللك دليلاً قاهراً ،والعجب أن موسى عليه السلام قال : أنوكأ

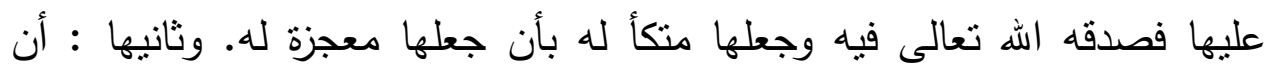

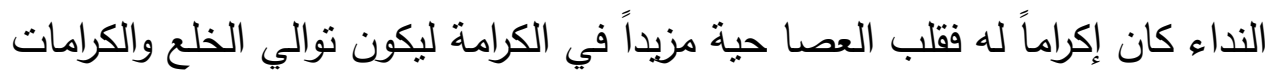

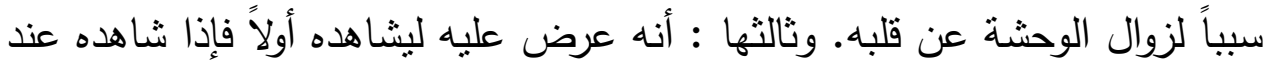

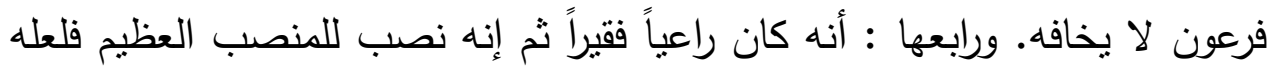

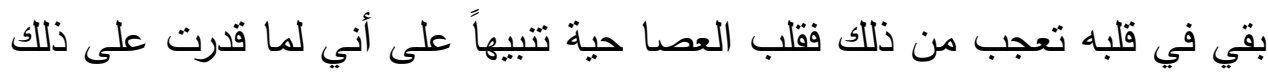

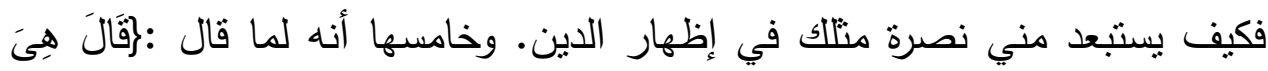

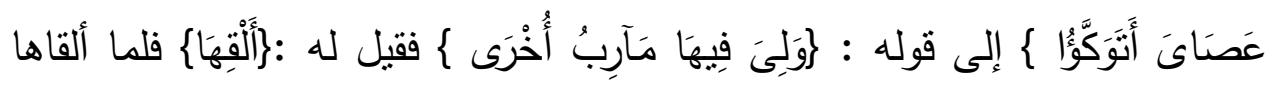
وصارت حية فر موسى عليه السلام منها فكأنه قيل له : ادعيت أنها عصاك وأن

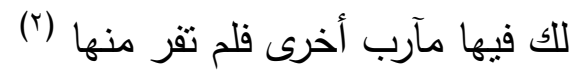
إذن قلب العصا حية هنا دليل نبوة لسيدنا موسى عليه السلام واصطفاؤه

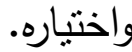

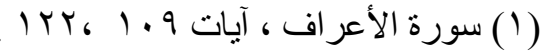

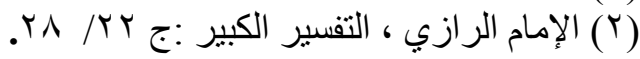

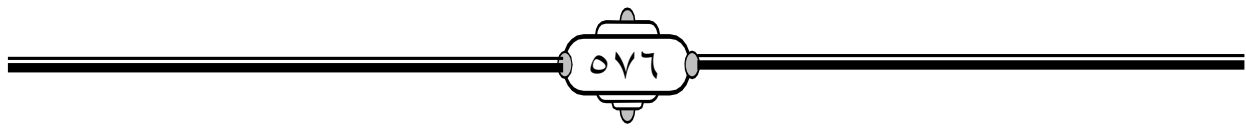


أما عن تحولها في المرة الثانية ،هذه العصا التي تتحوّل إلى ثعبان مبين، قد ناسب أن تكون تلك المعجزة لإثبات وجود الله تعالي بالنسبة لفرعون لأنه كان ينكر

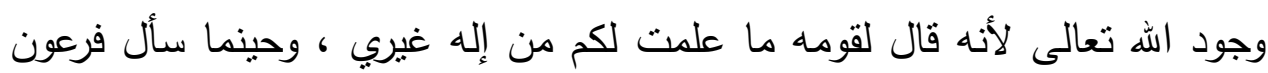
سيدنا موسى وقال لها قال فمن ربكما يا موسى ) فجاءت ثلك المعجزة لإثبات وجود الله تعالي ودليل علي نبوة سيدنا موسى عليه السلام ، فجمعت بين الأمرين ؛ أما تكرارها في المرة الثالثة ،لإثبات أن المعجزة تأتي من جنس ما اشتهر به قوم كل نبي ، فجاءت من جنس ما اشتهر به قوم فرعون وتميّزوا به، حتّى بدركوا حينما يرون الحقّ أنّ ذلك خلاف ما صنعته أيديهم، وأخرجته عقولهم من أمورٍ مزيّفة وسحر ظاهر، فقد تميّز قوم فرعون بوجود سحرة ماهرين، يخيّل إلى النّاس أنّهم يحوّلون عصيّهُه إلى ثعابين حقيقيّة، وقد رأى السّحرة الحقّ المبين حينما تتافسوا مع موسى عليه السّلام فجعلوا له موعدًا يوم الزّينة؛ حيث أظهر الله الحقّ بتحوّل عصا موسى عليه السّّلام إلى ثعبان عظيم يلتقم ما أخرجه السّحرة من السّحر والزّيف، وقد خرّ السّحرة عندما رأوا ذلك ساجدين، وقالوا آمنّا بربّ العالمين ، وهذه هُه المعجزة الخارقة تدل علي قدرة الله تعالي وعلي نبوة موسي عليه السلام ، كما تبين

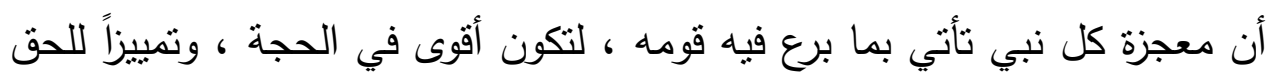

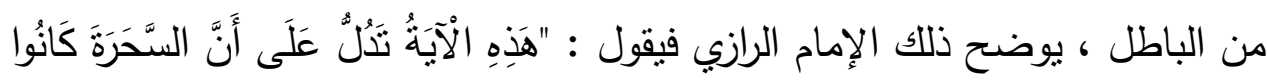

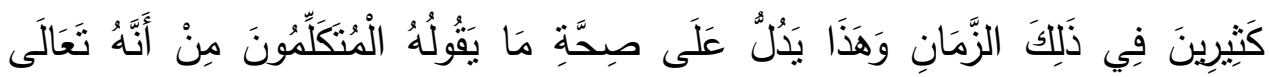

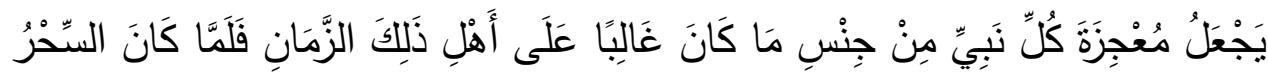

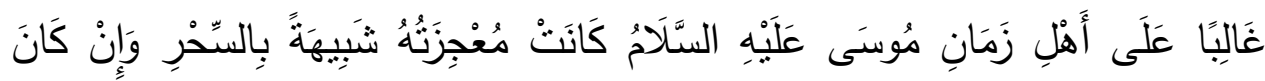

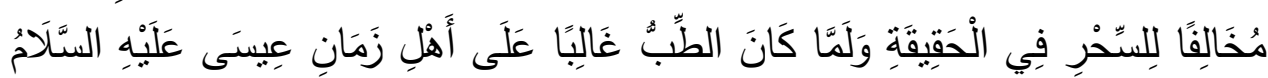

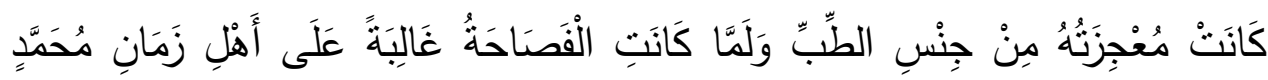

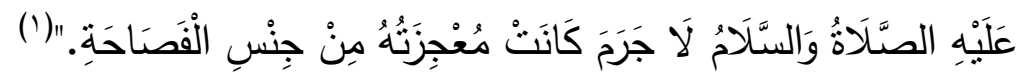

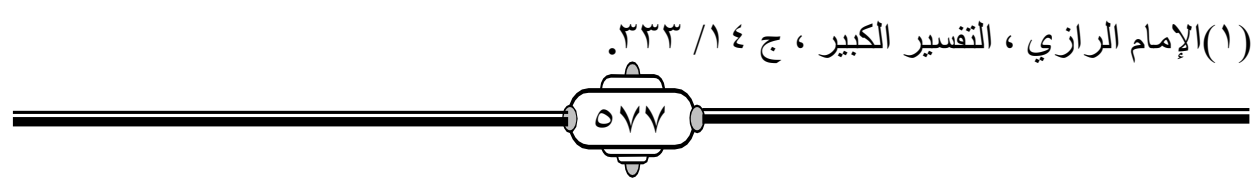


لكن هنا سؤال هل حدث لهذه المعجزة تحد ، وهل وقع بها تحد ؟ وللإجابة

نقول : عند تعرضنا لتعريف المعزة عند مفكري المسلمين ، عرفها الإمام الرازي

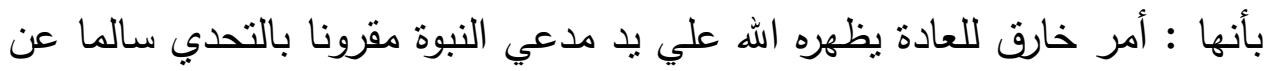

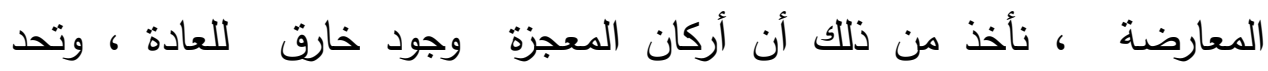

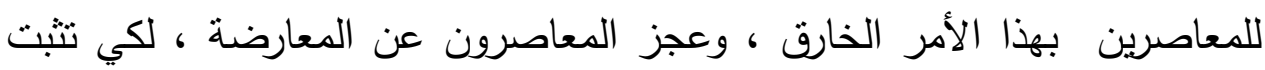
تلاك المعزة ويلزم منها ثبوت نبوة هذا النبي صاحب تلك المعجزة ، فهل حدث تحد

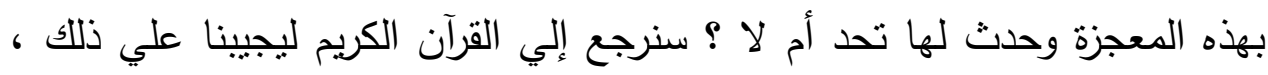

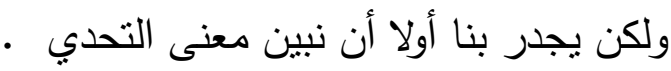
تعريف التحدي في اللفة: ورد لفظ التحدي في معاجم اللغة بعدة معان منها :-

1- المباراة والغلبة :- قالت العرب : تحديت فلانا إذا باريته في فعل ونازعته

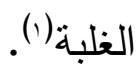
r - الغضب والمخالفة :وحَدَّ عليه يَحِدُّ حَدَداً وحَدَّدَ واحْتَدَّ :غَضِبَ، وحادَّهُ : غاضَبهُ وعاداهُ وخالَفَهُ (؟) والمعنى المراد هنا هو المعنى الأول بمعنى المباراة والغلبة. اصطلاحا : قيل : الإتيان بالمتل علي سبيل المنازعة والغلبة ويتحدد المنل تبعا لما يُتحدى به ، وقيل هو إنذار شخص بفعل شيء مع التلميح إلي عدم قدرته عليه ، وقيل هو طلب المعارضة في شاهد دعواه من النبوة(") .

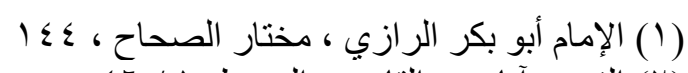

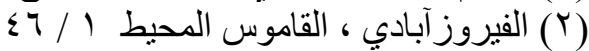

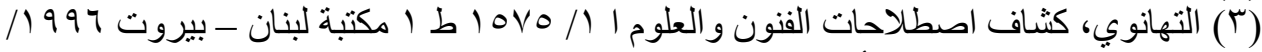

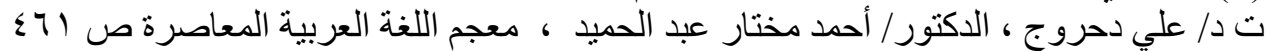

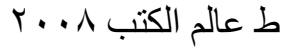


وبالنظر في معجزة العصا لسيدنا موسى عليه السلام نري أنها فعل خارق للعادة ، لأنها كانت مما لم يعتده الناس ، ومقرونة بالتحدي ، وسلمت عن المعارضة ، والدليل علي التحدي أن الله تعالي جعل سيدنا موسى يعاين تلك له المعجزة أول مرة حين عودته من أرض مدين إلي مصر ، فخاف سيدنا موسى عليه

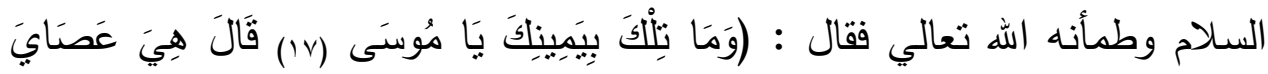

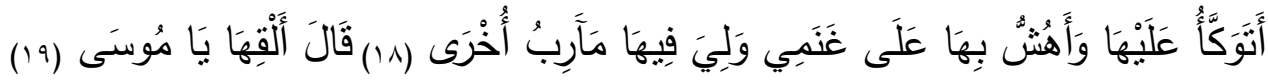

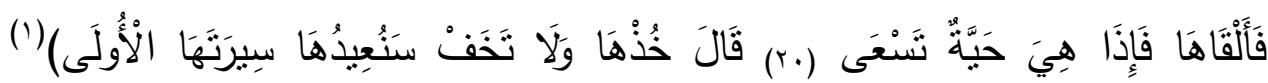
فكان هذا بيان من الله تعالي لموسى عليه السلام أن هذه العصا فيها معجزة له ودليل صدق علي نبوته، ثم تكررت تلك المعجزة مرة أخري أمام فرعون عندما طلب منه أن يرسل معه بني إسرائيل حتى يكون فيها اطمئنان من جانب سيدنا موسى عليه السلام وثقة في نصر الله تعالي له أمام فرعون هتى إذا اتهمه وملأه بالسحر

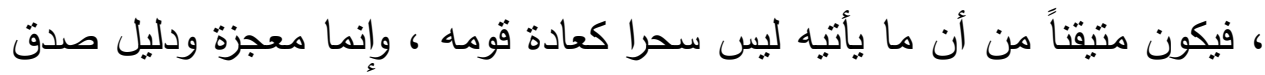
علي نبوته ، لأنه رآها قبل ذلك ، وبذلك يستطيع أن يتحداهم إذا هم أرادوا أن يتحدوه وقد كان ،فعندما ذهب إلي فرعون امتنالا لأمر الله تعالي ليدعوه إلي عبادة الله وأنه رسول رب العالمين ،ومنقذ لبني إسرائيل من بطش فرعون ، طلب منه الآية والدليل



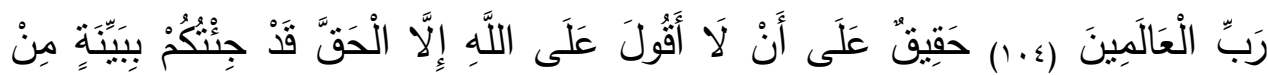

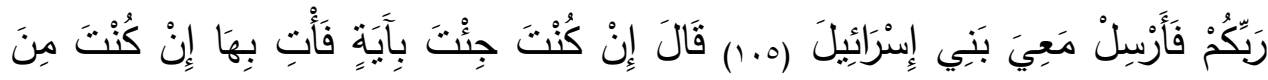

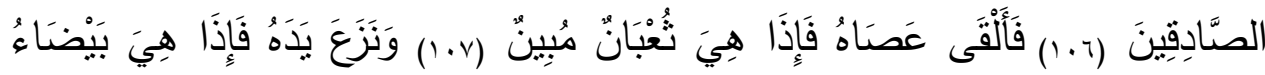

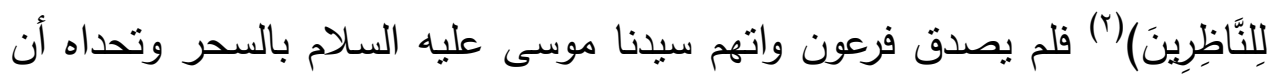
يأتيه بسحر متله ، لأنه شاع بينهم عمل السحر ، فلو لم يكن هنالك تحد لآمن

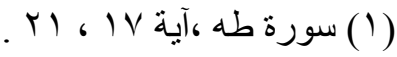

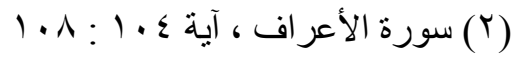


فرعون بتلك المعجزة حين رآها أو كذب فقط ولم يقل لسيدنا موسى عليه السلام

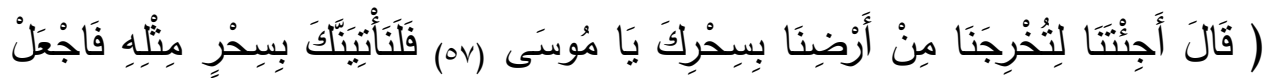

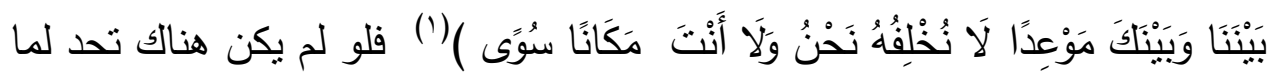
جمع فرعون السحرة بعد أن رأى هو تلاك المعجزة ، ومما يدل علي التحدي أيضا أن فرعون بعث في جميع المدائن ليأتوه بأمهر السحرة ووعدهم بالقربى منه والتشجيع بالمال أيضا إن كانوا هم الغالبين ، وإذا كان التحدي هو الإتيان بالمنل علي سبيل

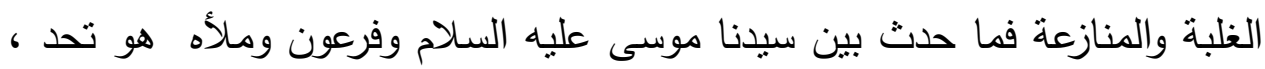
حتى وإن كان من طلب التحدي هو فرعون ولكن قبول سيدنا موسى عليه السلام لذلك مع تحذيرهم من العاقبة فهو تحد وإن لم يُصرح به ، يوضح الإمام الإيجي ذلك "هل يشترط التصريح بالتحدي وطلب المعارضة كما ذهب إليه بعضهم ،الحق أنه لا يثنترط بل يكفي قرائن الأحوال منل أن يقال له أي لمدعي النبوة إن كنت نبيا فأظهر معجزا فقعل بأن دعا الله فأظهره فيكون ظهوره دليلا على صدقه ونازلا منزلة التصريح بالتحدي(r) ودليل آخر علي التحدي أن أفضل عمل اشتهر به أهل مصر في تلك الفترة هو السحر ، كما كان أفضل ما اثتهر به العرب وقت بعثة النبي محمد صلى الله عليه وسلم هو البلاغة والفصاحة فحينما دعا سيدنا موسى عليه السلام فرعون إلي عبادة الله وأنه رسول رب العالمين وآراه الآية والعلامة لم يتهمه إلا بما هم فيه بارعون وهو السحر ، حتى يجري التحدي فيما هم فيه بارعون أيضا، كما حدث مع القرآن الكريم ، وقد كان التحدي عيانا بيانا أمام الناس جميعا وفي أظهر وقت من النهار وهو وقت الضحى ، وفي يوم عيدهم يوم تجمعه ، ثم النهاية

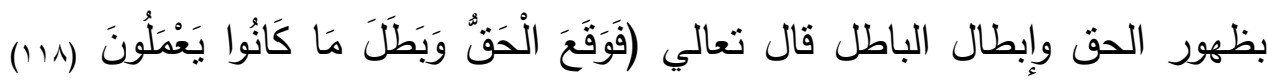

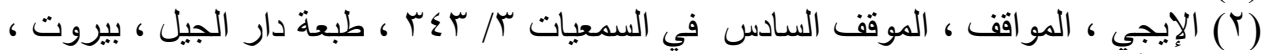

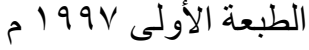




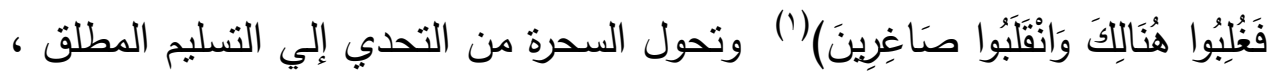
لأنهم علموا أن ما جاء به موسى لبس سحرا ، وهو فوق مقدور البشر ولذلك خروا سجدا ولم يفكروا ولم يعترضوا ، ومما يدل علي التحدي أيضا وجود طرفين ( سيدنا موسى عليه السلام وفرعون ) وجود زمان ومكان وشهود علي ذللك التحدي

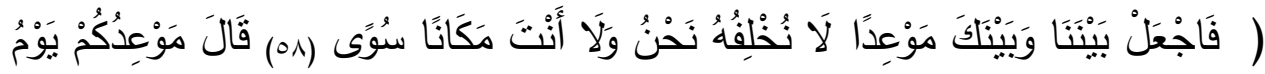

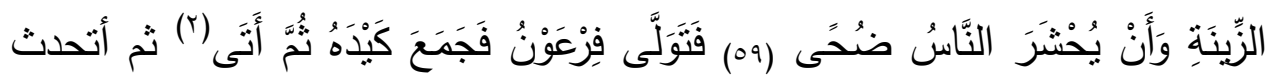
عن الركن الثالث وهو السلامة عن المعارضة .

تعريف المعارضة في اللغة:

ورد لفظ المعارضة في اللغة علي عدة معان منها :

1- الإتيان بالمثل :- قالت العرب : عارضته بمثل ما صنع: إذا أتيت إلبه بمنل

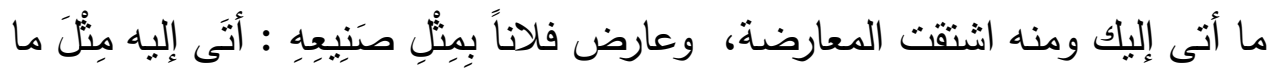

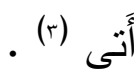
r- المقابلة :- تقول العرب: وعارض الثيء بالثيء معارضة قابله، وعارضت كتابي بكتابه أي قابلته، ومنه يعارضني ، أي يباريني ، فالمعارضة لغة: المقابلة على سبيل الممانعة وعبر عنه بعضهم بأنه إقامة الثيء في مقابلة ما يناقضه(؛). | (صطلاحا : (ص)

1- قيل : هي إقامة الدليل علي خلاف ما أقامه عليه الخصم(ه)

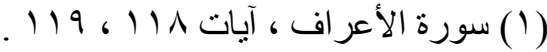

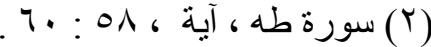

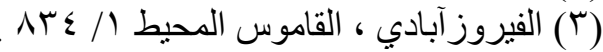

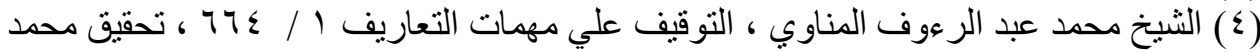

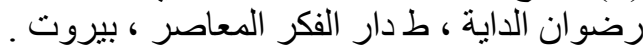

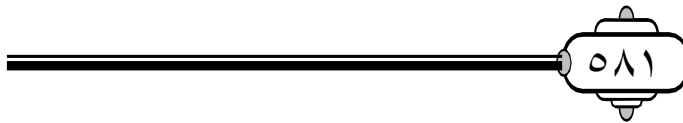

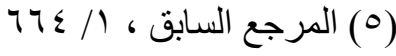


r - قيل : هي إبطال السائل ما ادعاه المعلل واستدل عليه بإثباته نقيض هذا

المدعي ،أو ما بساوي نقيضه ،أو الأخص من نقيضد(1) r - قيل : هي إنشاء كلام جديد باستحداث معنى بديع رائع أخاذ، به يغالب القرين قرينه في قوة اللفظ وجزالته، ويصارعه في عظيم معناه وروعته أو هي: إنشاء كلام جديد يحدث فيه صاحبه من المعاني البديعة والصياغات المثنازة ما يجاري

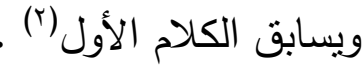

هذه التعريفات يكمل بعضها بعضا ، لكن تعريف الثيخ محي الدين عبد الحميد هو الأقرب ، لأن من يريد معارضة أحد لابد من التعرف علي موضوع المعارضة ودراسته ومحاولة التقوق علي المعلل ، وهذا ما حدث مع سيدنا موسى عليه السلام. ويوضح هذا الأمر الدكتور محمد عبد الله دراز ، حين يتحدث عن الثبهة الثالثة من الثبهات التي تثار حول إعجاز القرآن الكريم من حيث الإتيان بمثله ومعارضته فيقول : "وهذا قد يبدو للك عجيبا أن يزداد شعور المرء بعجزه عن الصنعة بقر ما تتكامل فيها قوته ويتسع بها علمه ، ولكن لا عجب ، فتلك سنة الله في آياته التي يصنعها بيديه لا يزيدك العلم بها والوقوف علي أسرارها إلا إذعانا لعظمتها وثقة بالعجز عنها ، ولا كذلك صناعات الخلق ، فإن فضل العلم بها يمكنك منها ويفتح للك الطريق إلي الزيادة عليها ، ومن هنا كان سحرة فرعون هم أول المؤمنين برب موسى وهارون ، وذلك ما حدث لسحرة فرعون حينما تحدوا موسى

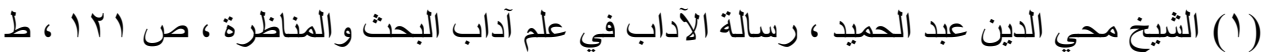

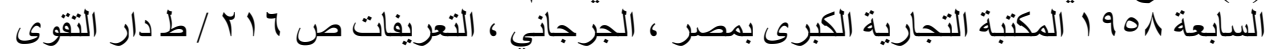

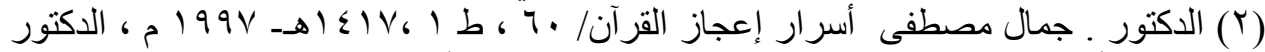

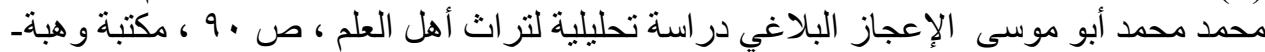

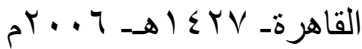


بصنعتهم البشرية الحبال والعصي ،التي تحولت إلي حيات تسعى في خيال من يراها ، في مقابل صنعة الخالق التي انقلبت فيها العصا حية تسعى تلقف ما صنعوا ، فلما علم السحرة بذلك آمنوا وهذا تحد ، لأن السحرة يعلمون قواعد السحر الذي صنعوه ، وأنه ليس حقيقة ، فلما تجلت الحقيقة واضحة أمامهم لم يملكوا إلا الإيمان بالله تعالي ( وشتان ما بين الصنعتين)(') . ومما يدل علي عدم وجود مانع من المعارضة ، أن التحدي كان من فرعون لموسى لما كان يظنه من أن موسى ساحر، فكان التحدي والمعارضة في حدود صنعتهم التي يفاخرون بها وهي السحر وهم المهرة فيه ، وذلك من أسرار أن تكون المعجزة من جنس ما برع فيه قوم ذللك النبي، وبذللك نستطيع أن نقول : إن معجزة سيدنا موسى عليه السلام ( العصا ) كانت من المعجزات التي أيد الله بها سيدنا

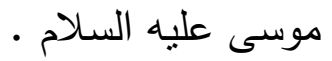

\section{وهنا سؤال هل تبقى المعجزة بعد موت التبي أم تتتهي بموته ؟ وللإجابة نقول: اختلف العلماء في تلكك المسألة :}

سبق أن قلنا: إن المعجزات أنواع ، معجزات عقلية معنوية وهي القرآن الكريم وهي باقية وخالدة سواء في حياة النبي أو بعد موته لأن الله تعالي تكفل بحفظه [إِنَّا

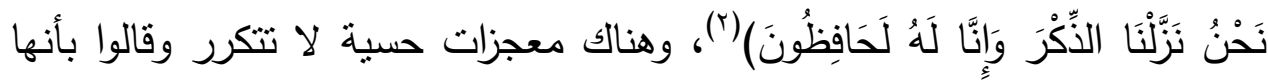
تتنهي في حياة النبي أي بعد حدوثها وهناك معجزات حسية متكررة وهي تتتهي بعد موت النبي المؤيد بتلك المعجزة، وأما ذكرها وتأثنيرها فيستمر بتواتر أخبارها ،وينقطع بانقطاع أخبارها وهذا ما ينطبق علي معجزة العصا لسيدنا موسى عليه السلام ،

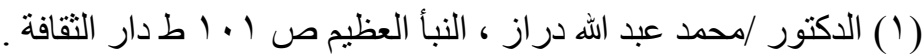

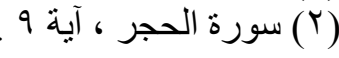


لأنها مادية حسية متكررة ، وهناك معجزات مادية غيبية ، وهي ما يخبر به النبي عن الغيب الماضي أو الحاضر أو المستقبل ، وهذه تحدث وتتقرض سواء في حياة النبي أو بعد موته ، وما حدث منها وإن لم نعاصره ، وما سيحدث منها وإن لم

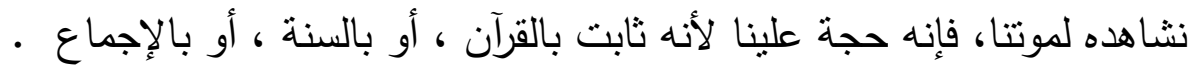
: تعقيب

معنى ما سبق أن معجزة سيدنا موسى عليه السلام ( العصا ) معجزة حسية مادية متكررة تتنهي بموت النبي ، ولكن لنا رأي في تلك المسألة قد نخطئ وقد نصيب، فأقول :إن معجزات الأنبياء جميعا سواء الحسية المادية المتكررة وغير المتكررة والمعجزات المعنوية لا تتنهي بموت الأبياء لعدة أسباب منها ، أن معجزات الأنبياء سواء كانت قولا أو فعلا أو تركا هي من أقوال الله تعالي وأفعاله ، وأقوال الله وأفعاله لا تتتهي ، وأيضا أن هذا دليل علي أن الحكمة البالغة وخوارق العادات التي حدثت أو وقعت علي يد الأنبياء عليهم السلام ما زالت ولا نزال تتحدي العجز البشري عن الإتيان بمنلها كالقرآن الكريم ،وإحياء الموتى بإذن الله تعالي ، وأما من يقول بانتهاء المعجزات زمنا ،فنقول :أي ينقطع مجيئها ولكنها لا تتتهي ني اعتقادا، لأنها دليل صدق علي نبوة الأنبياء ،حتى وإن انتهى زمن النبوة وخُتم بسيدنا محمد صلى الله عليه وسلم ،إلا أن أخبار المعجزات باق ما بقي القرآن يتلى، هذا الكتاب الخالد الذي بيّن أن تلك المعجزات دليل علي صدق ذلك النبي الذي أيده الله بها ، إذن تبقى المعجزات ذكرا واعتقادا ،فهي دليل النبوة ،وأن أخبارها باقية ببقاء القرآن الكريم لم تنقع ، وستظل نبراسا يهتدي الناس بها في إعمار الأرض وبناء الحضارات ، وهذا ما نريد أن نوضحه من معجزة سيدنا موسى عليه السلام .

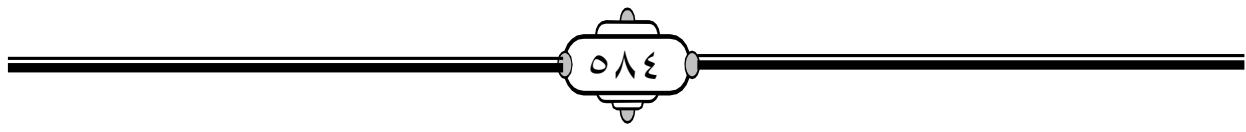


ץ - الوجه الثاني :-الإعجاز في ضرب الحجر بالعصا (استخراج الماء )

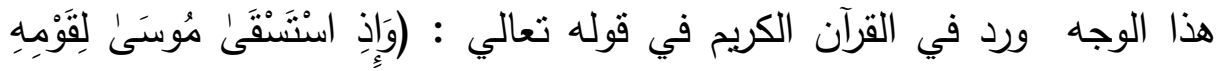

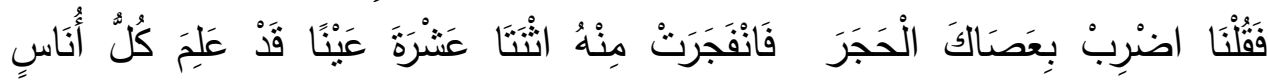

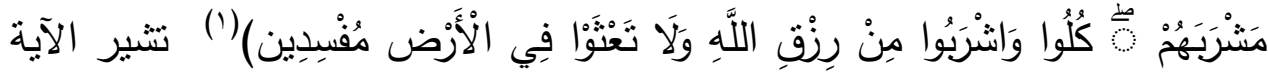
الكريمة هنا إلي أحد الإنعامات التي أنعم الله بها علي بني إسرائيل أن الله تعالي

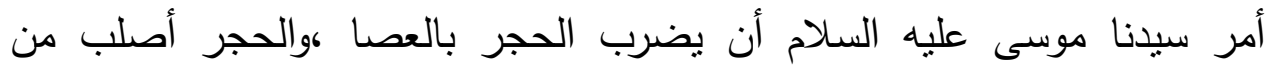
العصا فكيف ذلك ؟ إنه الإعجاز فالعصا التي تحولت حية تسعي تحولت هنا آلة أصلب من الحجر كي ينفلق ويخرج منه الماء ، فهي تنين وجها من وجوه الإعجاز

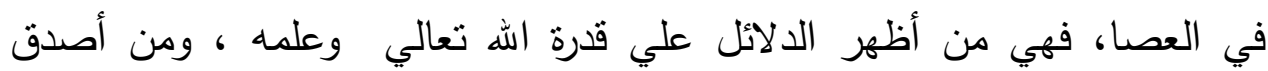
الدلائل علي صدق سيدنا موسى عليه السلام .

وقد تتاول المفسرون تلك الآيات التي حكت قصة عصا سيدنا موسى بالتوضيح والبيان ،ولكنهم لم يتتاولوها من جهة الإعجاز إلا في تلققها للعصي والحبال في يوم المناظرة بين سيدنا موسى وفرعون وملأه ، ولكن قول موسى عليه السلام ولي فيها مآرب أخري ، بيان لأكثر من وجه من وجوه إعجازها واستخداماتها فقد كانت سببا

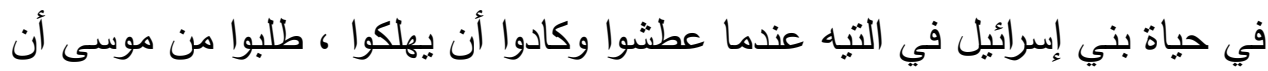

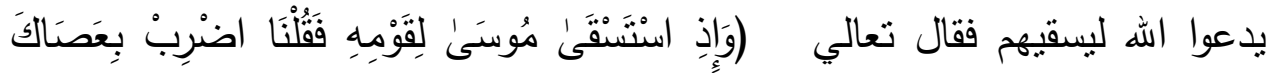

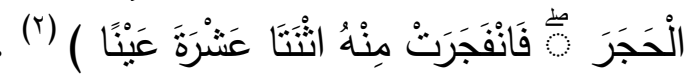

قيل في وصف الحجر: أنه كان حجرا طوريا حمله معه وكانت تتبع من كل وجه ثلاث أعين تسيل كل عين في جدول إلى سبط ، أو حجرا أهبطه آدم من الجنة ووقع إلى شعيب عليه السلام فأعطاه لموسى مع العصا ، وأنه لما أمكن أن يكون إنى من الأحجار ما يحلق الثعر ويجذب الحديد لم يمتتع أن يخلق الله حجرا يسخره 
لجذب الماء من تحت الأرض أو لجذب الهواء من الجوانب ويصيره ماء بقوة التبريد

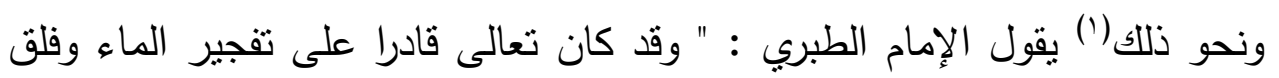
الحجر من غير ضرب لكن أراد أن يربط المسببات بالأسباب حكمة منه للعباد في فهم المراد وليرتب على ذلك ثوابهم وعقوبتهم وصولا في المعاد (؟).

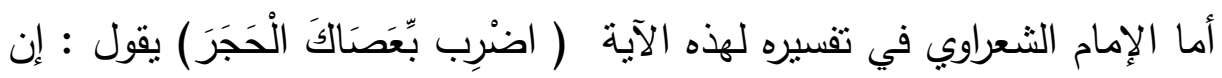

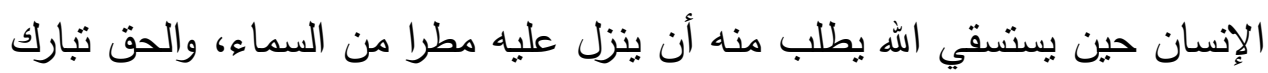

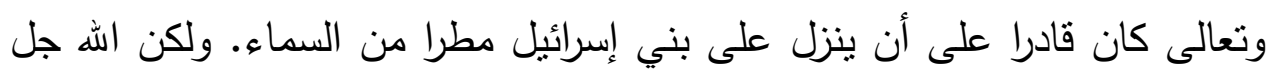

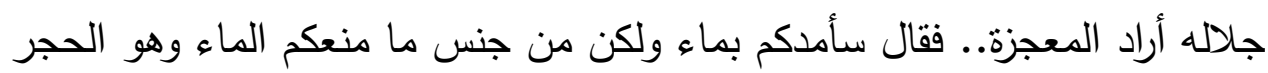
الموجود تحت أرجلكم، لن أعطيكم ماء من السماء.. ولكن الله سبحانه وتعالي أراد

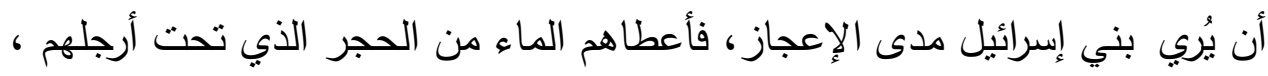

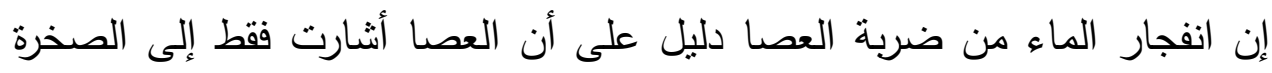

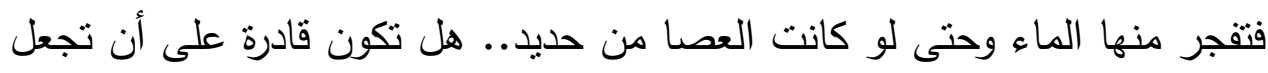

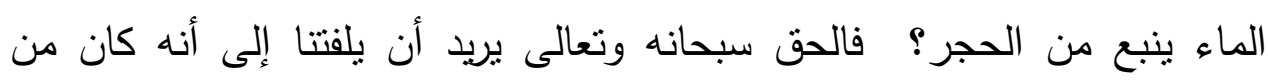

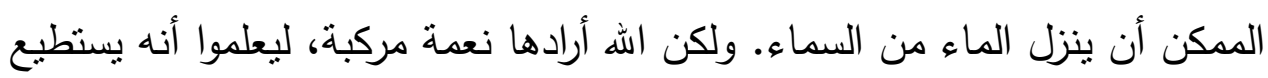

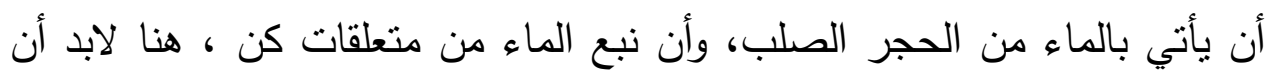

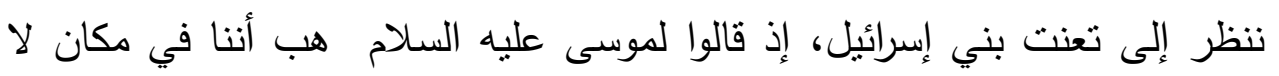

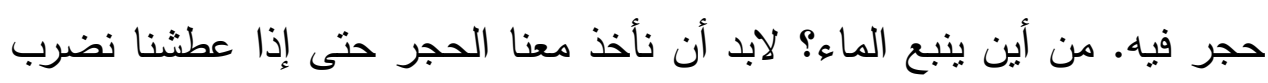

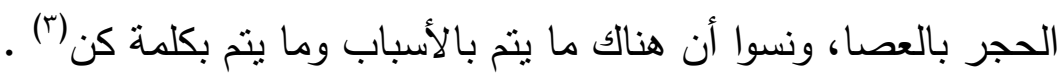

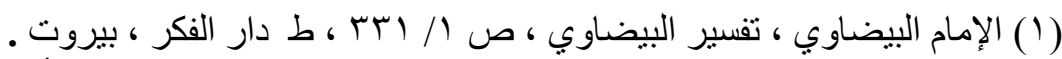

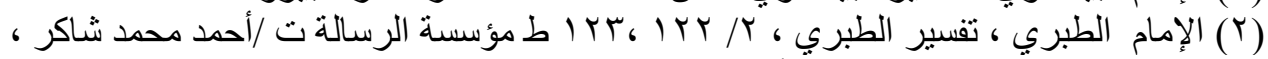

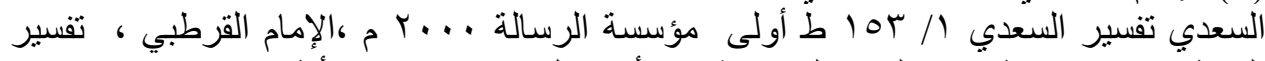

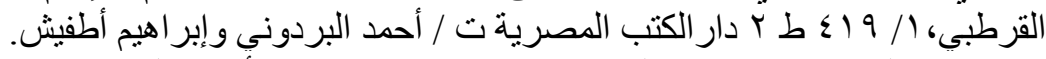

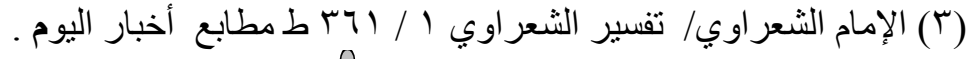


وهكا بقية التفاسير لم تخرج عن هذا السياق في تقسيرها لتلك الآية الكربمة وأن الإعجاز في جعل العيون اثتنا عشرة عينا وخروج الماء من الحجر •

أخلص من ذلك إلي أن الاستسقاء هو طلب السقيا أو الإسقاء ،فالسقي أن يجعل

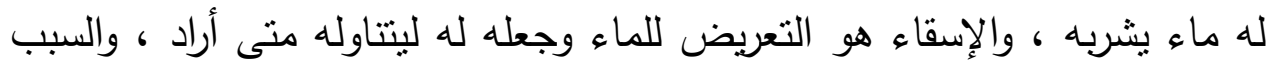
في طلب السقيا أن بني إسرائيل لما بقوا في التيه عطشوا فطلبوا من موسي أن يستسقي لهم فقعل ،وكان من الممكن أن تكون السقيا بتفجير الأرض عين ماء كما حدث مع السيدة هاجر أم سيدنا إسماعيل حينما عطش سيدنا إسماعيل ، أو ينزل الغيث من السماء كما يصلي الناس صلاة الاستسقاء فينزل المطر ،لكن أراد الله تعالي أن يكون ارتواء بني إسرائيل حينما عطشوا معجزة لنبيهم فانفجر الماء من الحجر الصلب بأمر الله تعالي حينما قال لموسي "فقلنا اضرب بعصاك الحجر فانفجرت منه اثتنا عشرة عينا " و معجزة أخري أن تتفجر اثثتا عشرة عينا وليست

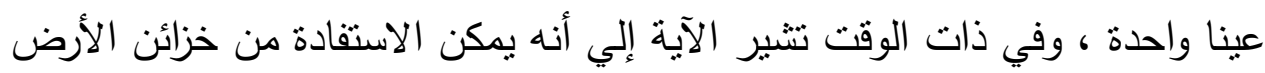
بآلات بسيطة وهي العصا ،وهي إثنارة للناس للسعي في الأرض واستخراج كنوزها ومنها الماء الذي هو سر حياة الإنسان والنبات والحيوان ،فبالماء تزرع الأرض به فينبت الزرع فيأكل الإنسان والحيوان ،كما أن بالماء تُحمل السفن في البحر فتنقل الناس والبضائع من مكان إلي مكان وتروج التجارة والتعارف بين الناس وتقام الحضارات

وقد كان استخراج الماء بهذه الطريقة و بهذه الآلة معجزة وبرهان لإثبات قدرة الله تعالي الذي يقول للثيء كن فيكون ،ولسيدنا موسي عليه السلام علي نبوته ،كما كانت تلك العصا آية أخرى عندما تحولت إلي ثعبان مبين في يوم المناظرة بين سيدنا موسي عليه السلام وفرعون وملأه كما بينا سابقا وهي معجزة بينة واضحة لا تلقبل الثك أو الجدل .

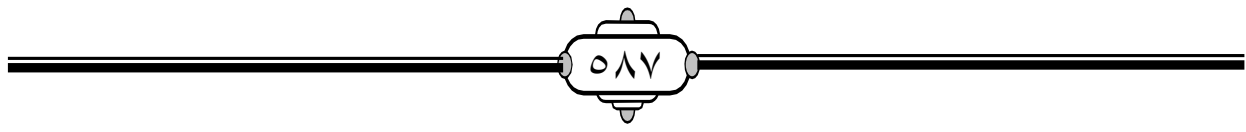




\section{من كم وجه يال هذا الانفجار على الإعجاز ؟}

"والجواب من وجوه : أحدها : أن نفس ظهور الماء معجز ، وثانيها : خروج الماء العظيم من الحجر الصغير ، وثالثها : خروج الماء بقدر حاجتهج ، ورابعها : خروج الماء عند ضرب الحجر بالعصا ، وخامسها : انقطاع الماء عند الاستغناء عنه ، فهذه الوجوه الخمسة لا يمكن تحصيلها إلا بقدرة تامة نافذة في كل الممكنات وعلم نافذ في جميع المعلومات وحكمة عالية على الدهر والزمان ، وما ذالك إلا

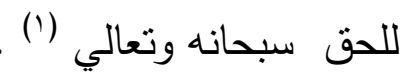
والثيخ سعيد النورسي كانت له رؤية أخري في تفسير تلك الآية حيث فال : وهي تشير إلى أنه يمكن الاستفادة من خزائن الرحمة المدفونة تحت الأرض بآلات

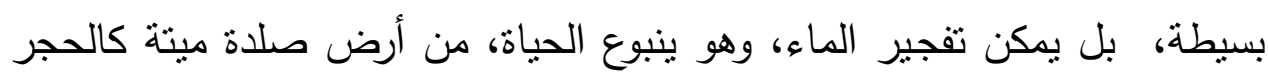
بوساطة عصا يوضح ذلك فيقول: "فهذه الآية تخاطب البشرية بهذا المعنى : يمكنكم أن تجدوا الماء الذي هو ألطف فيض من فيوضات الرحمة الإلهية، بوساطة عصا،

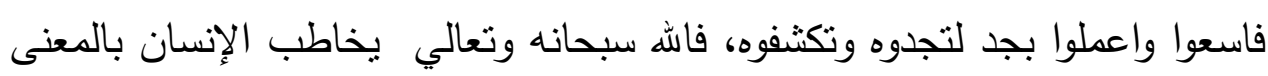

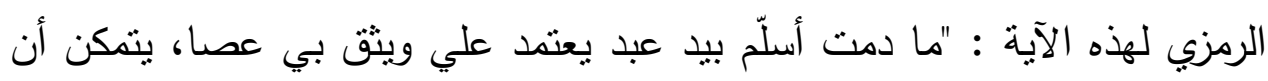
يفجر الماء أينما شاء فأنت أيها الإنسان إن اعتمدت على قوانين رحمتي، يمكنك لئك

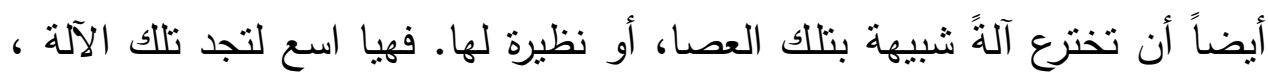
فانت ترى كيف أن هذه الآية سباقة لإيجاد الآلة التي بها يتمكن الإنسان من

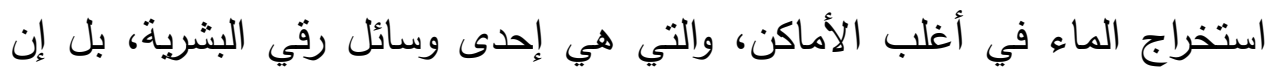
الآية الكريمة قد وضعت الخط النهائي لحدود استخدام تلأك الآلة ومنتهى الغاية منها(؟) وهذا نوع من التفسير الإشاري أو الرمزي لآيات القرآن الكريم ، لبيان كيفية

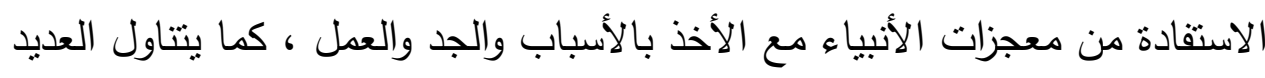

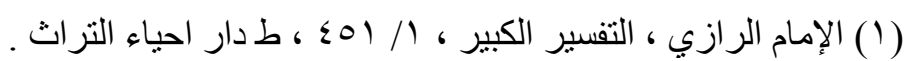

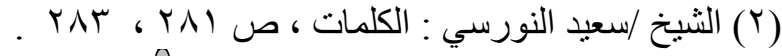

$$
\begin{aligned}
& 011
\end{aligned}
$$


من معجزات الأنبياء وبيين كيفية الاقتداء بهم واستخلالها لتقدم البشرية مثل ثلبين

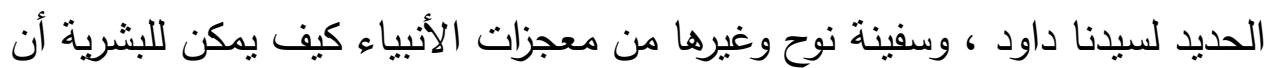
تستقيد من تلك المعجزات في التقدم والرقي للبشر جميعا ، فهذه الآيات الكريمة تستقطب أنظار البشرية عامة إلى هذه الحقيقة، وتلفت نظر السالفين والحاضرين إليها، فتنبه أولئك الذين لا يقدرونها حق قدرها ـ وهو ما يرجع إلي الاعتقاد الديني والتصديق القلبي بأثز الإيمان بالمعجزات علي السلوك البشري وكيفية تقويمه وتهذيبه ،والإيمان بالوحي الإلهي مصدر النبوة والمعجزات . نخلص مما تقدم : أن كل معجزة من معجزات الأنبياء عليهم السلام تشير إلى صناعة من الصناعات البشرية، والأنبياء قدوتتا في العمل وتعليم الصناعات والأخذ بالأسباب ، وما دامت الآيات التي تخص معجزات الأنبياء عليهم السلام لها نوع من الإثشارة فقط إلى خوارق التقدم العلمي والصناعي الحاضر، ولها طراز من التعبير

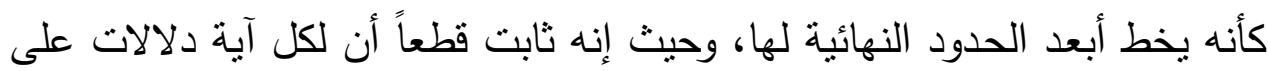
معانٍ شتى بل هذا متفق عليه لدى العلماء فلذلك وجب التتبيه علي ذلك ،ومع ذلك لا وجه للخلط بين المعجزة التي هي فعل الله تعالي وبين الفعل البشري -فنشتان ما بين الفعلين - ولما كان هناك أوامر مطلقة لاتباع الأنبياء عليهم السالم والاقتداء

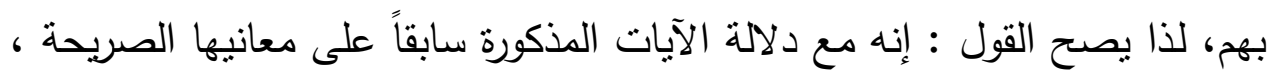
هنالك دلالات مشوقة بأسلوب الإشارة إلى أهم العلوم البشرية وصناعاته(') . يتبين لنا من تفسيره وفهمه لتلك المعجزة العظيمة، ماذا يمكن أن يتعلم الناس منها، وما يمكن أن بستفيدوه منها في العصر الحديث وكيف كانت معجزاته تعالى

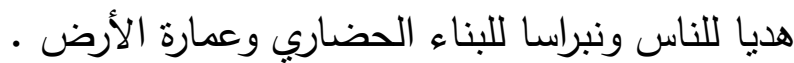

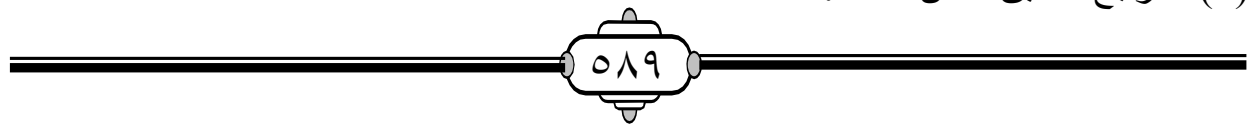




\section{r- الوجه الثالث ضرب البحر بالعصا (شث الطرق ) :}

وجه آخر من وجوه الإعجاز في عصا سيدنا موسى عليه السلام ،أنه ضرب بها البحر فصار طريقا يبسا عبر فيه سيدنا موسى وقومه ،وقد وردت ثللك القصة في

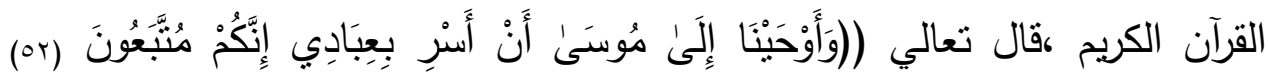

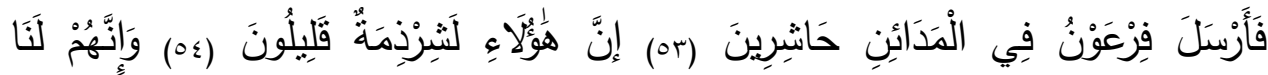

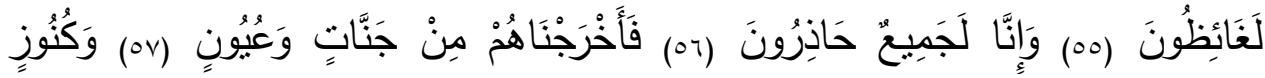

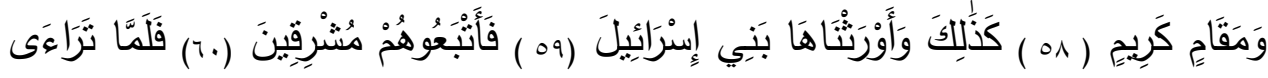

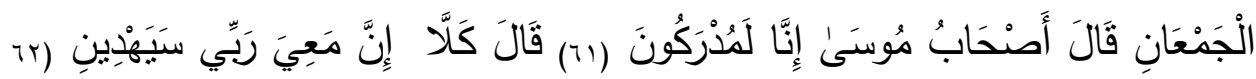

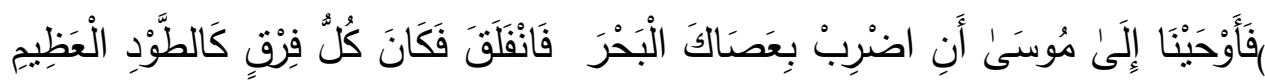

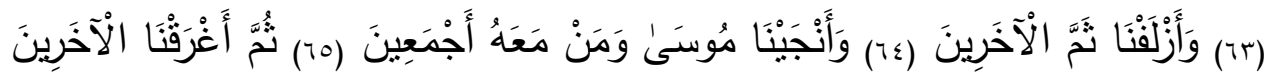

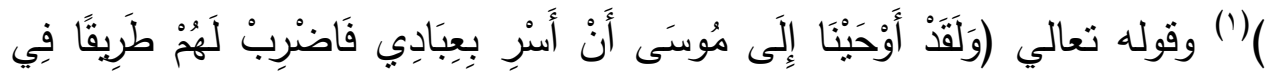

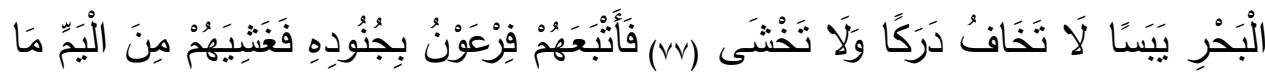

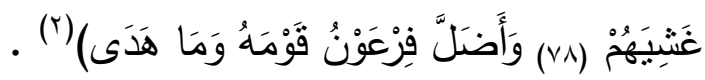
فكما ضرب سيدنا موسى عليه السلام اليابس بالعصا ( الحجر) فصار ماء وكان منجاة لبني إسرائيل من العطش، ضرب هنا الماء بالعصا فصار يابسا ، فكان منجاة لبني إسرائيل أيضا من بطش فرعون ، وكان في ذات الوقت مهلكة لفرعون وجنوده وهذه بعض تفاسير تلاك الآية الكريمة " أمر الله موسى عليه السلام حين أبى فرعون أن يرسل معه بني إسرائيل أن بسري بهم في الليل، وينقذهم من قبضة

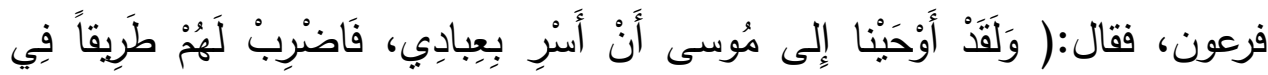

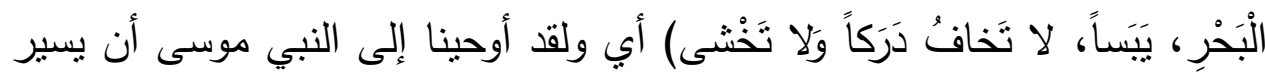
بيني إسرائيل من مصر ليلا، دون أن يشعر بهم أحد، وأمرناه أن يتخذ أو يجعل لهم 
طريقا يابسا في وسط البحر ، وذلك أن الله تعالى أيبس لهم تلكك الطريق حتى لم

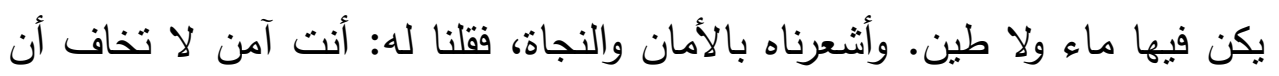
يدركك وقومك فرعون وقومه، ولا تخشى أن يغرق البحر قومك، أو لا تخاف إدراك فرعون ولا تخشى الغرق بالماء(') وهكذا بقية التفاسير لم تخرج عن هذا التفسير فلم يتحدثوا عن وجه الإعجاز في تحول البحر إلي يابس ، أو تحول الحجر إلي عيون

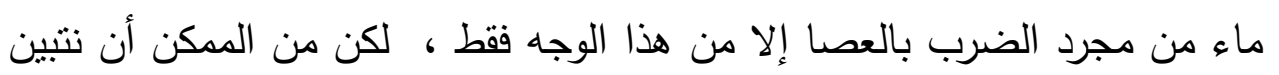
أموراً أخرى من تللك المعجزة ، وهذا ما سأبينه في النقطة التالية من كيفية الاستفادة

$$
\begin{aligned}
& \text { منها بعد زمن سيدنا موسى عليه السلام. } \\
& \text { 7. العصا بعد زمن سيدنا موسى : }
\end{aligned}
$$

إن معجزة العصا لسيدنا موسى في زمنه كان لها العديد من الفوائد الدينية والدنيوية كما بينا ، ولكن هل انتهت فائدتها وتأثيرها بعد وفاة سيدنا موسى عليه

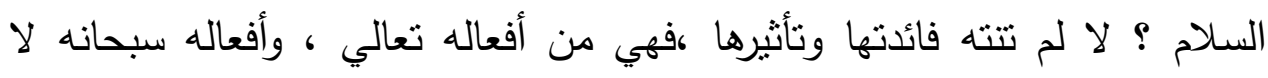
تتتهي ، والأنبياء قدوتتا وستظل معجزاتهم نبراسا ونورا يهدي البشرية إلي ما فيه خيرها ونفعها في الدين والدنيا ، في الدين المعزات دليل علي وجود و قدرة الله تعالي ، ونبوة الأنبياء ، وهما من أركان الإيمان التي لا يكمل إيمان العبد بدونهما ،

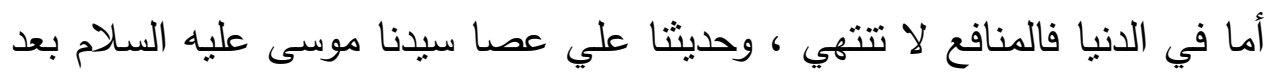
زمنه كالتالي:

إن من منافع العصا التوكأ عليها و الاحتماء بها ، وحمل الزاد والماء وغيرها من المنافع حسب بيئة المستخدم للعصا ، كما يمكن أن نستتبط منها تتمية الثروة

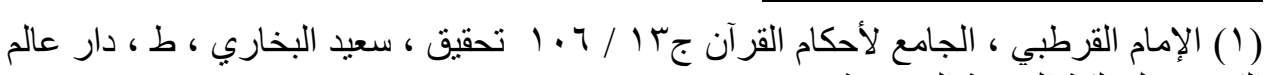
الكتب ، المملكة العربية السعودية. 
الحيوانية من إسقاط أوراق الأشجار للأغنام للأكل والمرعى • وتحويل تلاك الأوراق

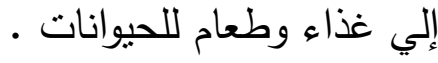

أما من ضربه للحجر بالعصا ففيه إثنارة إلي استخدام تلك العصا كعديد من الآلات ،فالعصا التي تحولت إلي ثعبان مبين ، هي الآن في العصر الحديث تتحول

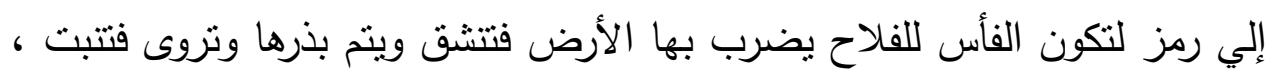

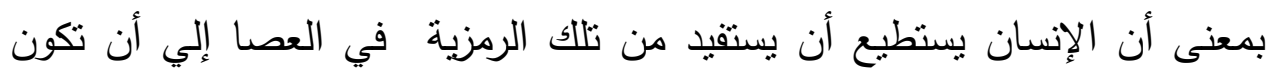

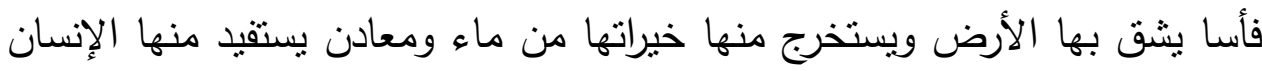

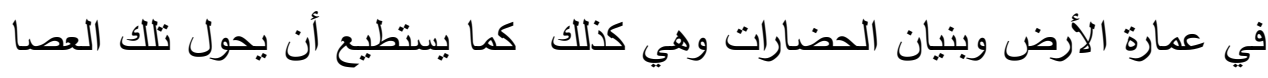

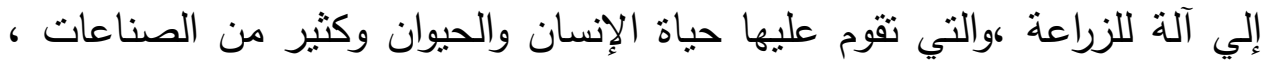

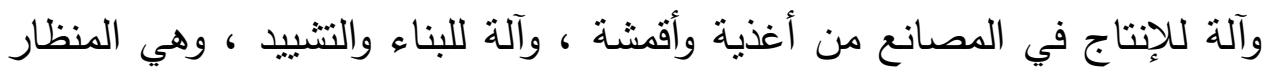

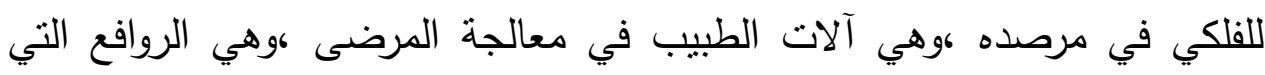
تساعد الإنسان في البناء والتشييد ،وهي الحفار الذي يستخرج به البترول من باطن

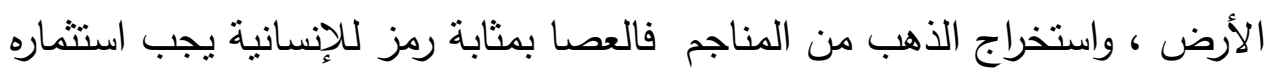

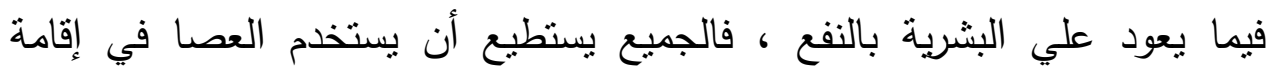

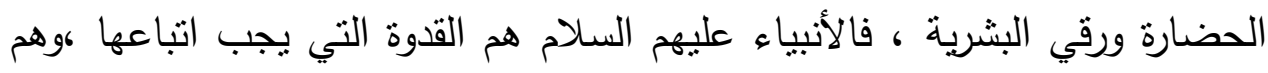

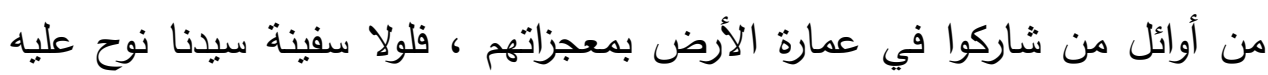
السلام ما عرف الناس السفن واستخداماتها ولولا صناعة سيدنا داود عليه السلام

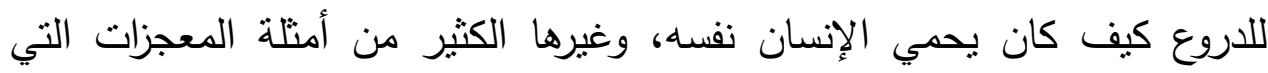
أفادت البشرية، فالعصا والحجر معجزة خارقة لسيدنا موسى عليه السلام، ورمزا وإثارة للناس للاستفادة منها، كيف ذلك ؟ أنه لا غنى للإنسان عن توظيف الأخذ الخدان

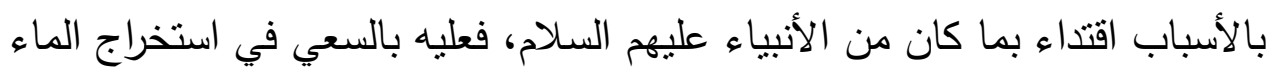

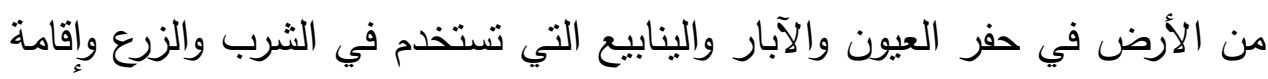
المجتمعات فما قامت المجتمعات والحضارات إلا حول وجود الماء، سواء في إقامة

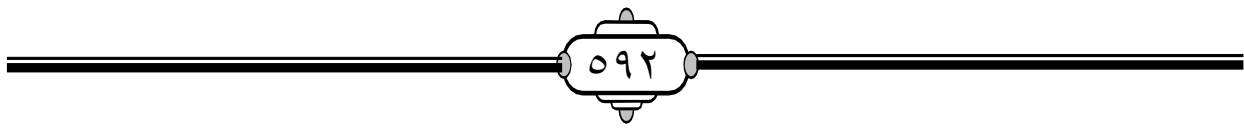


المدن المدنية ، كما حدث مع السيدة هاجر ووليدها سيدنا إسماعيل عليه السلام ، أو في العصر الحديث من القيام بالزراعة والتي قامت علي أساسها أعرق الحضارات ،كالحضارة المصرية القديمة في الوادي والدلتا ،إذن لم يكن ذلك الأمر ليتم ويصل إلي ذلك التطور والتقدم إلا بوجود رمز أو علامة يهتدي الناس بها مع الأخذ بالأسباب ،وقد تحدث كثير من العلماء المتخصصين في العصر الحديث عن إلى معجزات الأنبياء وما بمكن أن تقوم به من دور في عمارة الأرض • كما أننا من الممكن الاستفادة من ضرب العصا للحجر في استخراج البترول

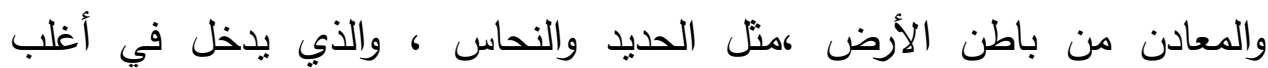
الصناعات التى قامت عليها الثورة الصناعية والتقدم ، وفي ذلك الكثير من المنافع التى تعمل علي عمارة الأرض وإقامة الحضارة ، وقد تتاول العديد من المفكرين المسلمين تلك المعجزات بالتقاط ما بمكن للبشرية أن تستقيده منها في العصر الحالي ، أخذاً من فوائد بعثة الرسل في تعليم الناس أمور المعاش . وقد التقط الثيخ النورسي ذلك فقال :" بأن تلك المعجزة قدمت للبشرية هدية لأنه ضرب العصا علي الأرض فانفجرت عيون الأرض المشار إليها في قوله تعالي

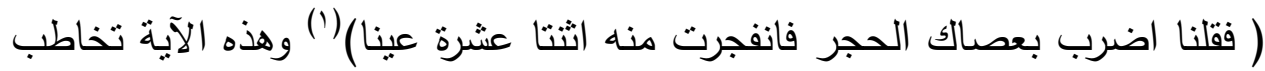
البشرية حيث يمكنكم لأن تجدوا الماء الذي هو ألطف فيض من فيوضات الرحمة الإلهية بواسطة عصا فاسعوا واعملوا بجد لتجدوا هذه الآلة وتوظيفها في العصر هور لهريه

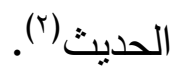

وقد فهم الثيخ النورسي أن هذه المعجزة يمكن توظيفها في حفر الأرض واستخراج المياه عن طريق الأنابيب ، التي حولت الصحراء إلي حدائق غناء ،ولولا معزة ضرب العصا لعاش الناس علي شواطئ الأنهار وحدها وهي لا تكفي ،

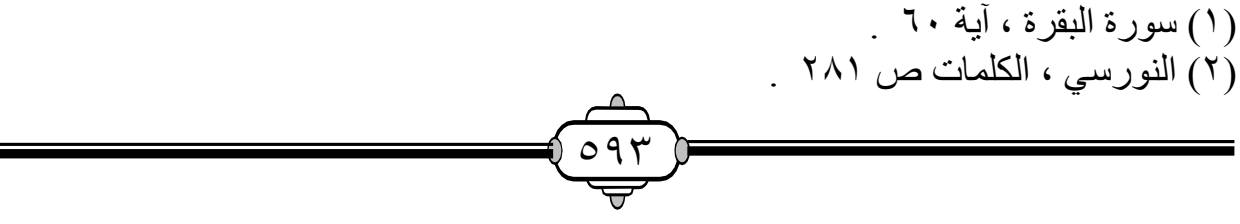


فيحدث التشاجر والتتاحر بين الناس وتزحف الصحراء حتى تغطي مساحات العمران وهنا يختل النظام ، كما أن ضرب العصا للأرض ساهم في استخراج البترول من الأرض ، الذي يدخل في كثثر من الصناعات منل الطاقة وتشغيل المحركات

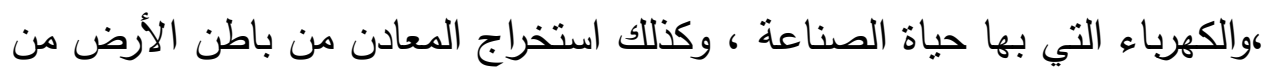
المحاجر والمناجم منل الذهب والذي دخل في كثير من الصناعات وفي علاج بعض الأمراض منل السرطان الخبيث ، والذي قام الدكتور مصطفى السيد بذلك العلاج ،ويبين لنا ذلك فيقول : " يتم ذلك عن طريق حقن الأوردة الدموية بدقائق من الذهب النانونية ، تذهب هذه الدقائق من الذهب إلى الجزء المسرطن من الخلايا ، ثم بتسليط الضوء على الذهب تتولد حرارة تميت الخلية السرطانية. لاحظ الدكتور

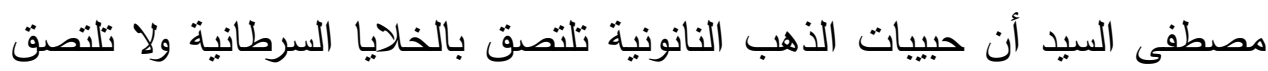
بالخلايا السليمة. لهذا فعند تسليط الضوء عليها فإن الخلايا السرطانية هي التي تتأثز بحرارة حبيبات الذهب فتسيح، أي تموت ولا تتأثز الخلايا السليمة قد أجريت تلك التجارب على حيوانات صغيرة منت الفئران وعينات تحت الميكروسكوب. أما تطبيق تلك التجارب على جسم الإنسان فيشترط تصريح الإدارة الصحية الأمريكية ، وقد اشترطت إجراء بحوث عن مصير حبيبات الذهب عند بقائها في جسم الإنسان. أي يجب أن يتبين أن تلك الحبيبات لا تضر الإنسان على التى المدى

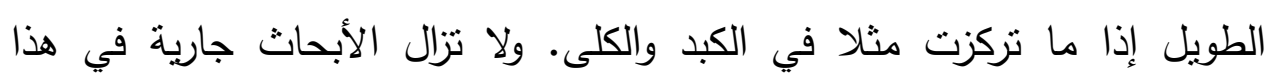

(') ( المضمار

وبعد هذه التجارب قامت جامعة رايس بالولايات المتحدة الأمريكية بتلك التجارب علي الإنسان وكانت النتائج كالتالي، والتي نُشرت في صحيفة العين الإخبارية : n

' ' المرجع ويكيبديا الموسو عة الحرة مصطفى_السيد_/ (عالم_فيزياء)/https://ar.wikipedia.org/wiki 
تجربة جامعة "رايس" تعد أول دراسة سريرية منشورة عن هذا الأسلوب، وهو تطور رئيسي في علاج يدمر الأورام دون الآثار الجانبية المنهكة حقق علاج للسرطان باستخدام جزيئات الذهب تم اختراعه في جامعة "رايس" الأمريكية نتائج واعدة في أول تجربة سريرية لهذا الأسلوب الذي يعتمد على معالجة السرطان بالحرارة الضوئية لتسخين الأورام وتدميرها ، وتجري فرق بحثية حول العالم بتجارب لعلاج السرطان باستخدام جزيئات الذهب، مع اختلاف في بعض التفاصيل الفنية، والمراحل التي تم قطعها في مجال التجارب ، وتعد تجربة جامعة "رايس" هي أول بال دراسة سريرية منشورة عن هذا الأسلوب، وهو تطور رئيسي في علاج يدمر الأورام دون الآثار الجانبية المنهكة التي يسبيها العلاج الحالي سواء الكيميائي والإشعاعي ، ووفق الدراسة المنشورة التي نشرتها دورية "PNAS" في V ب أغسطس/آب، فقد

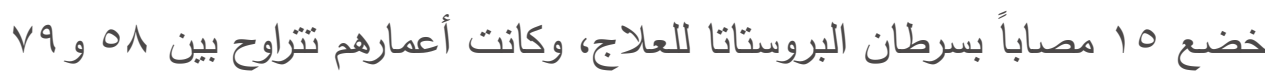
عامًا، وتتوعت درجة الإصابة من منخفضة إلى متوسطة الخطورة. ،ولم يظهر على rا منهم أي علامات مرضية يمكن اكتشافها بعد عام من العلاج بجزيئات الذهب في كلية "إيكان" للطب بجبل سيناء بنيويورك والجزيئات المستخدمة في العلاج هي بهات كرات صغيرة جداً في حجم النانو مصنعة من السيليكا مع طبقة خارجية رقيقة من الذهب، وهي أصغر بحوالي •ـ مرة من خلايا الدم الحمراء، وقد اخترعتها الدكتورة

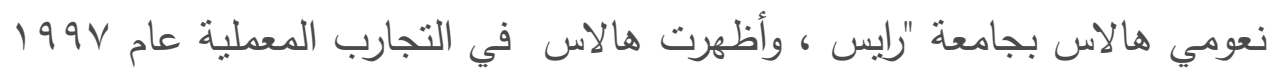

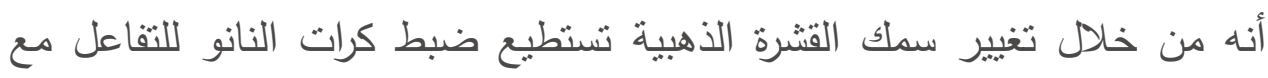
أطوال موجية محددة من الضوء ، وشاركت عام ... مع الباحثة ويست بيوكينير من جامعة ديوك للهندسة الحيوية، في ابتكار طريقة لتذمير الخلايا السرطانية عن طريق تشخين الجسيمات النانوية باستخدام ليزر منخفض الطاقة قريب من الأشعة تحت الحمراء يمكن أن يمر عبر الأنسجة السليمة ، واستخدمت هذه الطريقة المبتكرة مع النماذج الحيوانية قبل أن تصل إلي التجارب السريرية ، والتي تم من خلالها

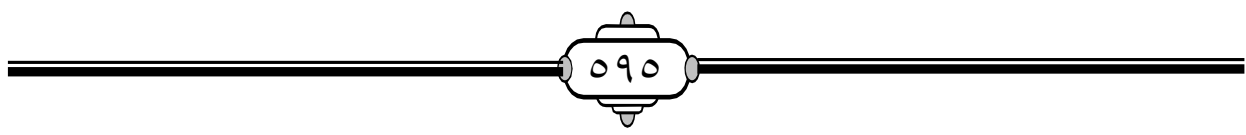




\section{علاقة معجزات الأنبياء بالتقاسم الحضاري}

تقديم العلاج للمرضى خلال يومين ، حيث ثم في اليوم الأول تسريب جزيئات الذهب النانوية إلي داخل الجسم عن طريق الوريد ، وفي اليوم التالي خضعوا لاستئصال الورم عن طريق تسخين هذه الجزيئات بالليزر ، وغادر جميع المرضى المستثفى إلي المنزل في اليوم الثالث ، وعادوا إلي اختبارات المتابعة .

وأضافت "المرضى الذين تم علاجهم، نجحنا في أن نجنبهم الآثار الجانبية للعلاج التقليدي القائم على الكيماوي أو الإشعاعي، ومنها عدم القدرة على التبول، حيث تسمح الطريقة الجديدة بتوجيه معالجة مركزة تشتهف المكان المصاب مع تجنب بقية البروستاتا (1)

كذلك استخراج الأحجار الكريمة التي تختبئ تحت طبقات الأرض والتي يستخدمها الناس في صناعة الحلي والزينة ، كذلك استخراج الرخام والجرانيت من الجبال لاستخدامه في أعمال البناء والتشبيد ، هذا من ناحية ضرب العصا للحجر أو الأرض، وقد تبين لنا العديد من المنافع ، وسوف يتبين للأجيال القادمة الكثير والكثير الذي ينفع الناس في حياتهم ومعاشهم.

أما علي الطرف الآخر وهو ضربه للبحر بالعصا ، فمنها منافع كثثرة من الممكن الاستفادة منها في العصر الحديث أيضا ،فالعصا التي تحولت حية تسعى ، وحولت الحجر عيون ماء ، هنا أيضا حولت الماء طريقا يابسا ، حيث إنه حين ضرب البحر بالعصا جف البحر وانقلب يابسا ، وهنا نتعلم ونستقيد منه في قيام

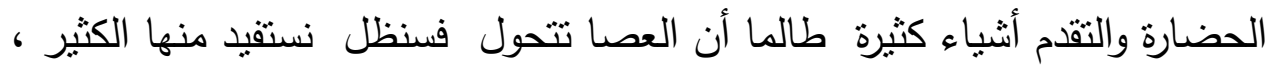
فضرب العصا للبحر والذي حول الماء إلي يابسة وشق طرقا للسير وكانت طريقا

${ }^{1}$ ( https://al-ain.com/article/clinical-cancer-treatment-gold-particles

صحيفة العين الإخبارية كيوم الإثنين r/ 9 / 9 | ـ ب م ،مقال بعنوان علاج السرطان بجزيئات الذهب حلم أصبح حقيقة الإخبارية

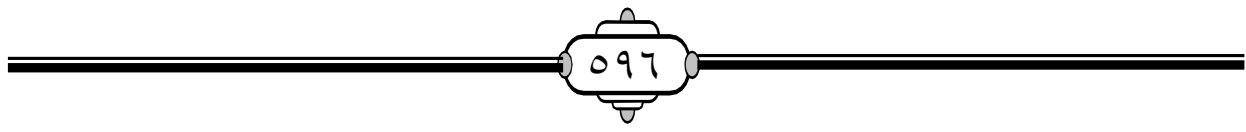


لنجاة موسي وقومه ، ففيها الرمز والعلامة والمنافع الكثيرة ، في جوانب فوائد البحار والمحيطات " حيث استطاع الإنسان أن يقيم المدن الساحلية التي تمتاز بالهواء النقي وتحافظ علي الجوانب الصحية ، و إنشاء الثواطئ والمدن الساحلية والفنادق العائمة، واثراء السياحة وزيادة الدخل القومي وإنعاش الاقتصاد ، وإقامة المدن الساحلية والثواطئ قامت عليها العديد من الصناعات منل صناعة السفن وإنثاء الموانئ والفنادق والقرى السياحية والثحن والتقريغ في الموانئ، وسياحة الترفيه ، ومن صناعة السفن استفاد الإنسان توظيفها في عمليات النقل ، والأكثر من هذا أنها دفعت العقل البشري لصناعة الموانئ العائمة التي تمتد علي سواحل البحار والمحيطات بحيث تتزود السفن فيها من غير رسو إلي الثاطئ اليابس ، كما استفاد الإنسان كذللك في عمليات نقل البضائع بسهولة ووقت قصير وبأسعار بسيطة إذا قورنت بأسعار النقل البري والجوي ، وقد كانت معجزة العصا هي الآلة وهي الآية ، وما علي الإنسان سوى السعي ، والبحث في تلك الآيات والمعجزات وكيفية الاستفادة منها في الحاضر والمستقبل.

كما يمكن تجفيف بعض المسطحات المائية وإنشاء المزارع السمكية وسد باب الاستيراد والاكتقاء الذاتي ، فالعصا هي رمز لما يستجد من أثياء في المستقبل ، وذللك يستفاد من قول سيدنا موسى عليه السلام ( ولي فيها مآرب أخرى ) فالعصا آلة ورمز من الممكن الاستفادة منها في تطور الحياة ، فمعجزة العصا لم تتوقف عند كونها معجزة لإثبات النبوة فقط ، وإنما عملها وأثرها مستمر إلي قيام الساعة ،

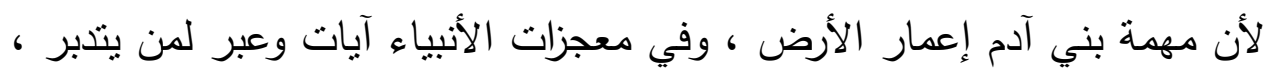
والاستفادة منها قائمة ، وما علي الإنسان إلا التدبر وإعمال عقله في الاستفادة من

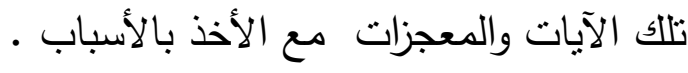

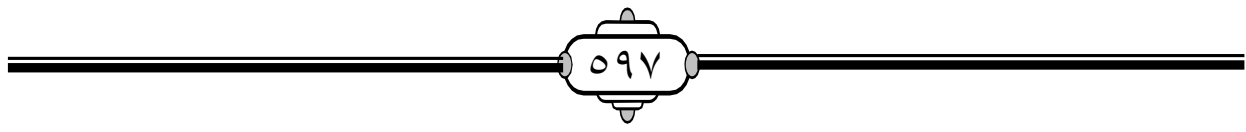




\section{الخاتمة}

الحمد لله الذي بنعمته تتم الصالحات ، حمدا بوافي نعمه ويكافئ مزيده ، وبعد

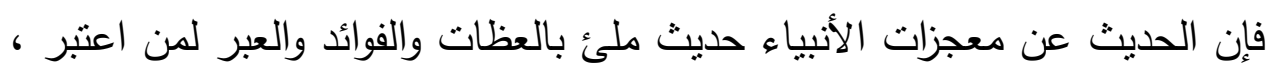
فلم تكن المعجزات دليل قدرة الله تعالي ، ودليل صدق علي نبوة الأنبياء فقط ، وإنما أيضا فيها من المنافع للبشرية الكثثر سواء الدينية أو الدنيوية والتي اتضحت لنا من خلا البحث ، والتي منها : 1- أن معجزات الأنبياء هي الرمز والنبراس للتقدم والتكامل الحضاري فنحن نمتلك ذلك التراث الثقافي والفكري الذي هو منبع وأساس أعرق الحضارات علي الإطلاق وهي الحضارة الإسلامية التي أضاءت جنبات العالم شرقه وغربه و الإيمان بتلك الك المعجزات وبيان ما فيها ، والآخر يمتلك المدنية والمال ، فهناك تقارب وتكامل بين

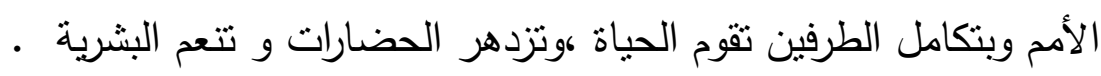
r- أن معجزات الأنبياء لم ولن نتوقف وستظل نبراسا ورمزا وآية للناس يأخذون

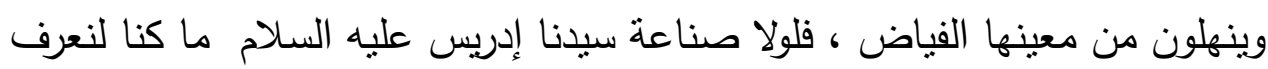
الملابس ، ولولا سفينة سيدنا نوح عليه السلام ما عرفنا السفن و الثحن والتقريغ ونقل البضائع والتجارة الدولية عبر البحار والمحيطات ، ولولا إلانة الحديد وصناعة سيدنا داود عليه السلام للاروع ما عرفنا تلك الصناعة للدروع والأسلحة ، وما كنا لنستطيع ونعرف صناعة الحديد والأسلاك وهي من أهم أسس الصناعة الحديثة

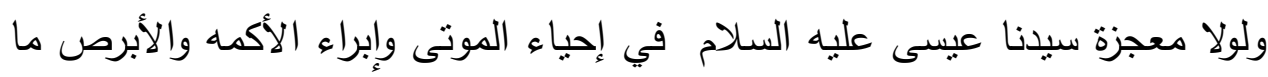
عرفنا الطب ، ولولا القرآن الكريم الذي قص علينا تلك المعجزات وأخبار تلك الأمم ومعزات الرسل مع أقوامهم ما عرفنا تلك المعجزات وكيفية الاستفادة منها ، ولا قامت حضارة .

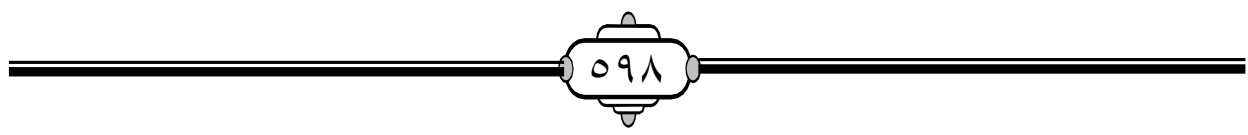


r- الحقيقة الواضحة أنها آيات وبراهين من الله تعالي يؤيد بها أنبياءه ورسله كثاهد صدق علي اصطفائهم ، وعلي قدرته تعالي الذي يخرج الضد من الضد الذي يخرج من الثجر الأخضر نارا ، كذلك هنا مع معجزة سيدنا موسي عليه

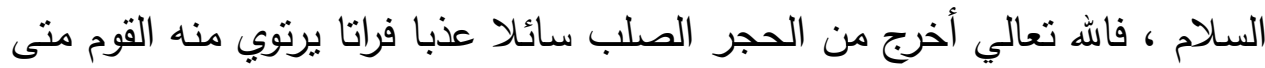
شاءوا ،وكان الضد تماما حين ضرب الماء ( البحر بعصاه ) فانقلب يابسا ومر موسي عليه السلام وقومه المؤمنين بسلام ، ثم انطبق علي فرعون وجنوده وغرقوا فكان الماء منجاة لموسى وقومه ، ومهلكة لفرعون وملأه ل

ع- أن معجزة سيدنا موسي عليه السلام لم ينته دورها إلي زمن سيدنا موسى عليه السلام ،لأن المعجزة فعل من أفعال الهه تعالي وأفعاله تعالي لا تتتهي لأنه حي قيوم وظلت آية ومعجزة لسيدنا موسي عليه السلام وسنظل رمزا وعلامة يتعلم منها • الناس في تقدمهم ومعاشهم

0- يجب علي الإنسان المؤمن أن يتفكر ويتدبر في أمور دينه ، ليُظهر صلاحية هذا الدين للإنسانية في ماضيها وحاضرها ومستقبلها ، فهو بحر فياض لا ينضب معينه أبدا ، والعقل ميزة الإنسان ، لا يمل من التفكر والتبر ، فليتكاملا في صوغ الحضارة وبناء الإنسانية .

وفي النهاية لا يسعني إلا أن أتضرع إلي الله تعالي أن أكون قد وُفيت هذا البحث حقه ، وإن كنتُ قد قصرت فليغفر الله تعالي لي زلتي ، وآخر دعوانا أن • الحمد لله رب العالمين 
ثبت المراجع والمصادر

$$
\begin{aligned}
& \text { القرآن الكريم } \\
& \text { ثانيا :- كتب الحديث }
\end{aligned}
$$

1- ابن حجر العسقلاني ، فتح الباري شرح صحيح البخاري، تحقيق الثيخ / محمد فؤاد عبد الباقي ، وأثرف علي طبعه الثيخ / محب الدين الخطيب، طبعة دار المعرفة بيروت بو r- الدكتورموسى شاهين لاشين ، فتح المنعم شرح صحيح مسلم ، دار الشروق

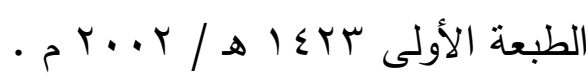
ثالثا:- كتب التفسير وعلوم القرآن ب- الباقلاني ، الإمام أبو بكر محمد بن الطيب (المتوفى: r.عه) ، إعجاز

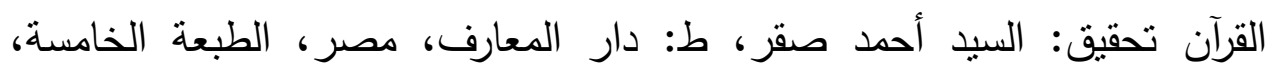
- $199 \mathrm{~V}$ ع- الجصاص، الإمام أحمد بن علي أبو بكر الرازي الحنفي(المتوفى • آهـ) أحكام القرآن تحقيق:محمد الصادق قحاوي، ط دار إحياء التراث العربي بيروت ه ــ اهـ. ه- الرازي ، الإمام فخر الدين محمد بن عمر بن الحسين، التقسير الكبير، طبعة

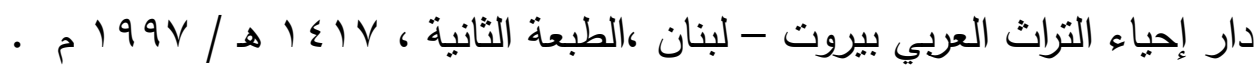
צ- الزرقاني، الثيخ محمد عبد العظيم( المتوفى Vדr ا هـ ) مناهل العرفان ، تحقيق د خالد السبت ، ط دار الفكر.

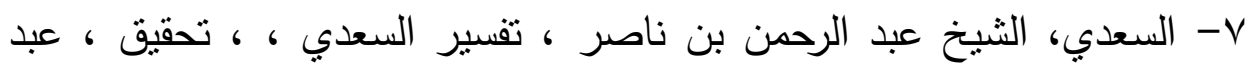

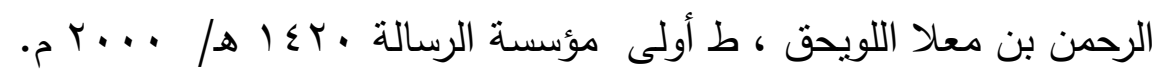

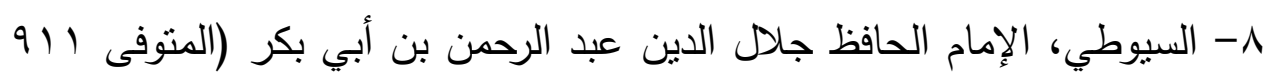
هـ) الإتقان في علوم القرآن ، ط مكتبة التوفيقية ، القاهرة.

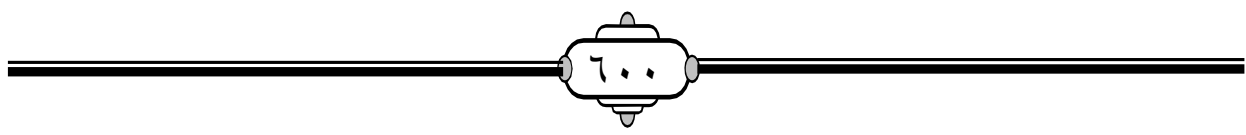


9-السيوطي، الإمام الحافظ جلال الدين عبد الرحمن بن أبي بكر (المتوفى الهو هـ) معترك الأقران في إعجاز القرآن دار النشر: دار الكتب العلمية - بيروت -

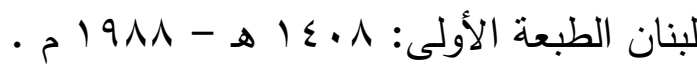

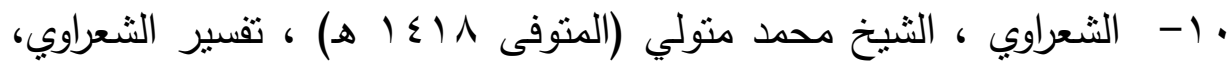
(الخواطر ) ط مطابع أخبار اليوم. |l- الثوكاني، الثيخ محمد بن علي بن محمد بن عبد الهه اليمني (المتوفى:

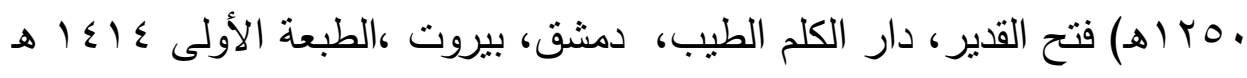
r ا - الصابوني، الثيخ محمد علي ،التبيان في علوم القرآن ، ط دار الإرشاد

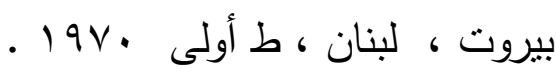
ץ| - الطبري ، الإمام محمد بن جرير (المتوفى · اس هـ ) ،تفسير الطبري ، تحقيق /أحمد محمد شاكر، طبعة مؤسسة الرسالة.

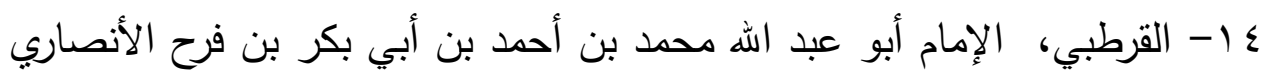

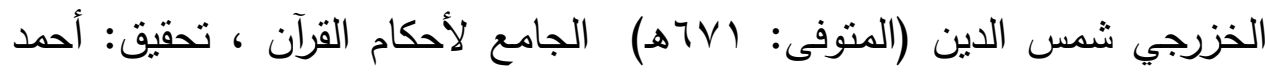
البردوني وإبراهيم أطفيش، ط : دار الكتب المصرية - القاهرة . 0 بهاء الدين بن علي خليفة الحسيني (المتوفى/ک؟باهـ) تفسير المنار، ط الهيئة

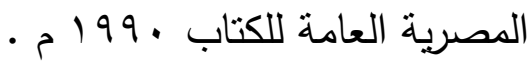
17 - الكلبي، الإمام محمد بن أحمد بن جزي (ت V V هـ ) التسهيل لعلوم التنزيل ، ط دار الفكر بيروت. V ا - ابن كثير، الإمام أبو الفداء إسماعيل بن عمر القرشي البصري(المتوفى:

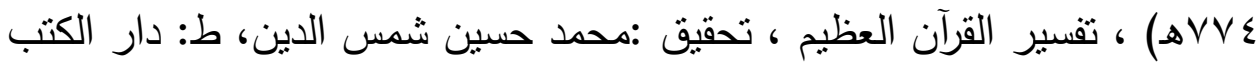
• العلمية، بيروت

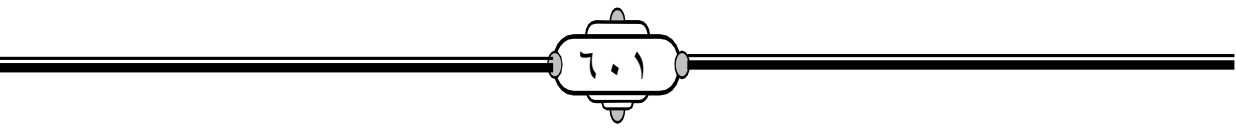




\section{علاقة معجزات الأنبياء بالتقاسم الحضاري}

1 ا - أبو موسى ، الدكتور/ محمد محمد ، الإعجاز البلاغي دراسة تحليلية لتراث

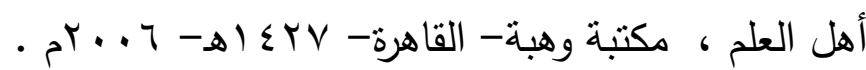

9 1 - دراز، الدكتور محمد عبد الله ، النبأ العظيم ، تخريج عبد الحميد الدخاخني ،

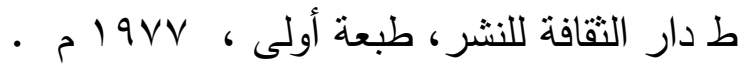
• . - عبد الرحمن، الدكتورة عائشة ( ت 19 1 1 هـ )، الإعجاز البياني للقرآن ومسائل ابن الأزرق ، ط دار المعارف ، الطبعة الثالثة .

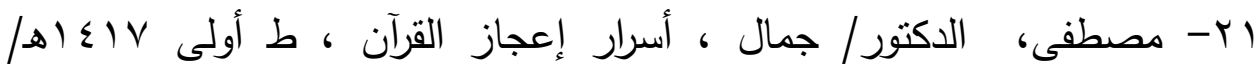
- $199 \mathrm{~V}$

رابعاً : - كتب العقيدة

r r- الآمدي، الإمام أبو الحسن علي بن أبي علي بن محمد بن سالم الثعلبي

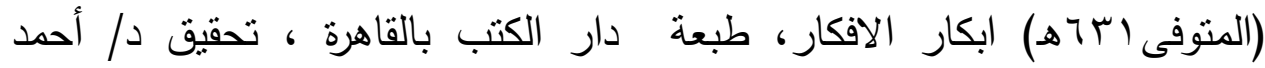

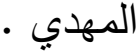
بr- الآمدي ، الإمام أبو الحسن علي بن أبي علي بن محمد بن سالم الثعلبي (المتوفى: ابآهـ) غاية المرام في علم الكلام، تحقيق: حسن محمود عبد اللطيف ، طبعة المجلس الأعلى للشئون الإسلامية - القاهرة. ع - الأسد آبادي ،القاضي عبد الجبار بن أحمد بن عبد الجبار الهمذاني،(المتوفى الإسيه 10 هـ ) شرح الأصول الخمسة ، ط مكتبة وهبة . ه - الأسد آبادي ، القاضي عبد الجبار، المغني في أبواب التوحيد والعدل ، التنبؤات والمعجزات، تحقيق الدكتور / محمود محمد قاسم ، بدون دار نشر . جr - الإيجي، الإمام عضد الدين عبد الرحمن بن أحمد بن عبد الغفار(المتوفى VO VO المواقف في علم الكلام ، تحقيق د.عبد الرحمن عميرة ،ط دار الجيل

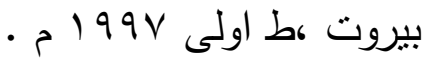

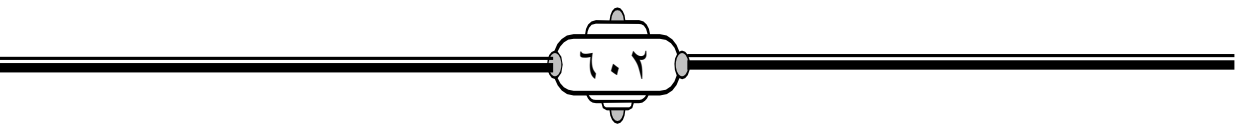


V V - الباقلاني، الإمام أبو بكر محمد بن الطيب(المتوفى: س.عـ) الإنصاف فيما يجب اعتقاده ولا يجوز الجهل به ، ط المكتبة الأزهرية للتراث ، تحقيق ،الثيخ

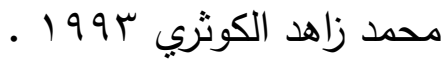

^ץ- الباقلاني ،الإمام أبو بكر محمد بن الطيب (المتوفى: r.عه) البيان عن الفرق بين المعزات والكرامات والحيل والكهانة والسحر والنارنجات، عني بتصحيحه ونشره الآب رتشرد يوسف مكارثي اليسوعي ، ط المكتبة الثرقية ، ساحة النجمة

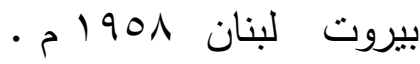
q ץ- البغدادي، الإمام عبد القاهر بن طاهر بن محمد التميمي ( المتوفى 9 ؟ع هـ)، أصول الدين ، ط دار الكتب العلمية ، بيروت ، لبنان .

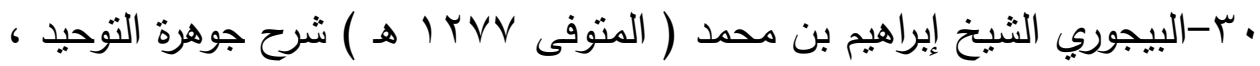

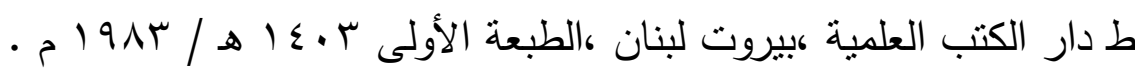
اب- البيضاوي، الإمام ناصر الدين أبو سعيد عبد الله بن عمر بن محمد الثيرازي البيضاوي (المتوفى: rس- البيهقي، الإمام أحمد بن الحسين بن عليّ بن عبد الله بن موسى الخُسْرَوْجِردي الخراساني (المتوفى: 0^§هـ) دلائل النبوة ، تحقيق عبد المعطي قلعجي ، ط دار الكتب العلمية ، بيروت. rس- التفتازاني، الإمام سعد الدين مسعود بن عمر بن عبد الله السمرقندي (المتوفى 1 V9 هـ) ، شرح المقاصد ، تحقيق الدكتور عواد سالم ، والدكتور عرفه النادي ، ط مكتبة الإيمان.

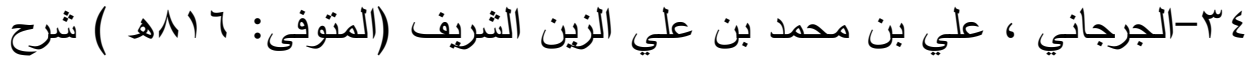
المواقف ، ط دار الكتب العلمية .

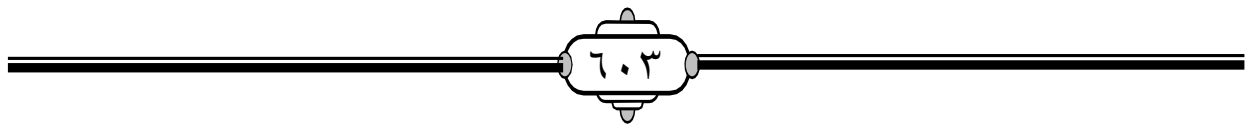


0r -الجسر، الثيخ حسين ( المتوفى VYr I هـ) الحصون الحميدية في حقيقة الديانة الإسلامية وحقيقة الثريعة المحمدية تقديم وتحقيق / خالد زيادة ، مكتبة

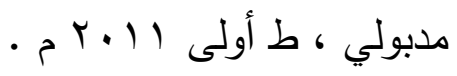

بr -الجويني، الإمام عبد الملك بن عبد الله بن يوسف بن محمد أبو المعالي، ركن

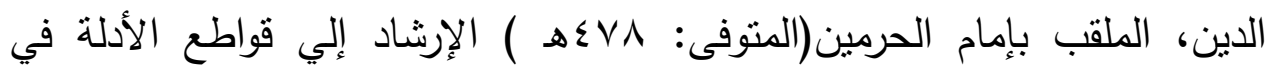

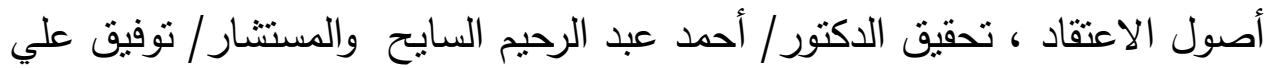
وهبة ، ط مكتبة الثقافة الدينية ، الطبعة الأولى 9 ، . ب م .

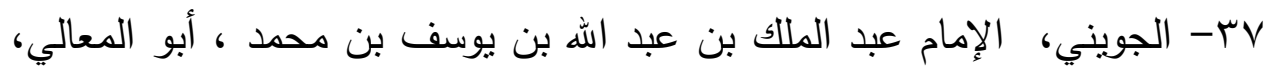

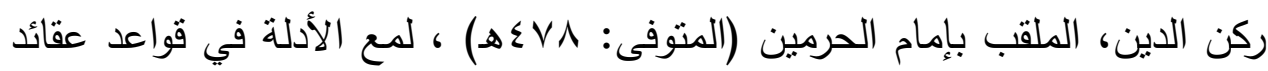
أهل السنة والجماعة ،تحقيق د : فوقية حسين محمود ، الناشر : عالم الكتب - لبنان

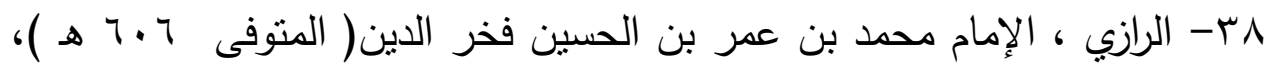
الأربعين في أصول الدين ، تحقيق الدكتور / أحمد حجازي السقا ، طبعة مكتبة الكليات الأزهرية. q - الرازي ، الإمام محمد بن عمر بن الحسين فخر الدين ، الإشارة في علم الكلام ، تحقيق / هاني محمد حامد ، ط المكتبة الأزهرية للتراث، والجزيرة للنشر النشري

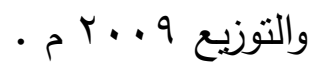

• ع- الرازي ، الإمام محمد بن عمر بن الحسين فخر الدين ، المطالب العالية تحقيق الدكتور/ أحمد حجازي السقا ، طبعة دار الكتاب العربي ، بيروت ، طبعة

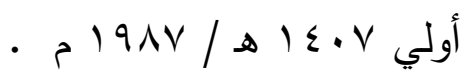
اء - الرازي، الإمام محمد بن عمر بن الحسين فخر الدين ، محصل أفكار المتقدمين والمتأخرين من العلماء والحكماء والمتكلمين ، ط مكتبة الكليات الأزهرية.

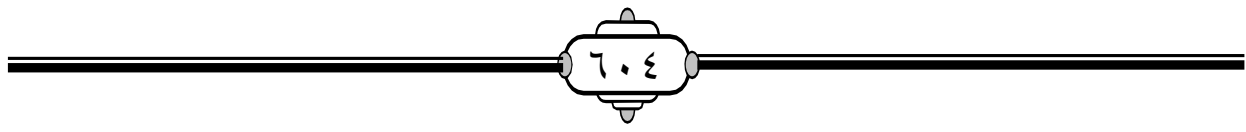


بـ -الغزالي ، الإمام أبي حامد محمد بن محمد الطوسي (المتوفى: 0.0ه ) الاقتصاد في الاعتقاد ، وضع حواثيه: عبد الله محمد الخليلي الناشر: دار الكتب

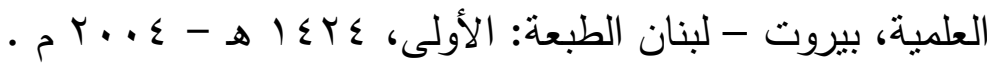
rع- الثناوي، الدكتور/ محمد مصطفي قضايا النبوة في ضوء الكتاب والسنة ، . 1997 b

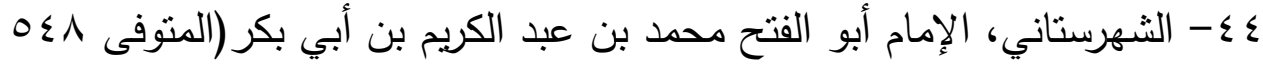
هـ ) ، نهاية الإقدام في علم الكلام ، طبعة دار عالم الكتب. 0؛ - الماتربدي ، الإمام محمد بن محمد بن محمود، أبو منصور الماتريدي (المتوفى: س بسهـ) التوحيد ، تحقيق : د. فتح الله خليف الناشر: دار الجامعات المصرية - الإسكندرية.

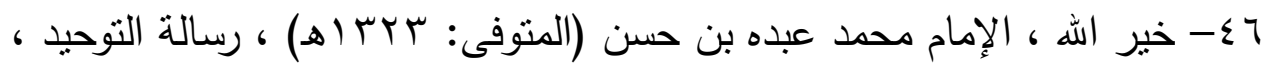
ط الهيئة العامة لقصور الثقافة . إ - خير الله، الإمام محمد عبده حسن ، الإسلام دين العلم والمدنية ، ، تحقيق

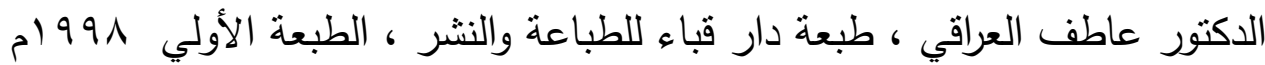
^ـ -سيف النصر ، الدكتور عبد العزيز ، البراهين العقلية والنقلية علي العقائد الإيمانية ، كبدون دار نشر ، طبعة ع . . . . سادسا : الكتب العامة 9 - صبري ، الثيخ مصطفى ، موقف العقل والعلم والعالم من رب العالمين وعباده المرسلين ، طبعة دار إحياء التراث العربي ، بيروت ، لبنان ، الطبعة الثانية $\cdot 01911$

•- الجار الله، عبد السلام صالح ، علاقة العلم التجريبي بمعجزات الأنبياء / الماء

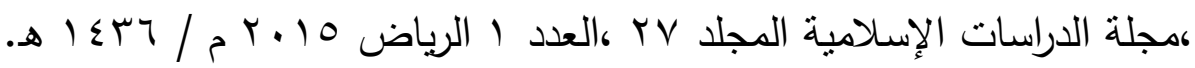

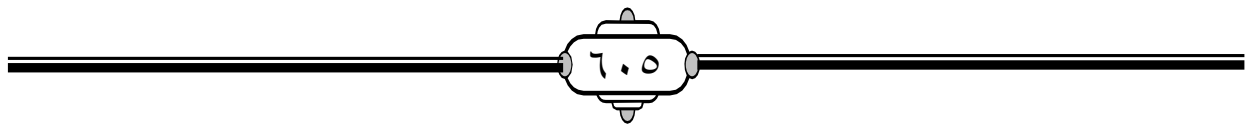


أ- الرومي، الدكتور فهذ بن عبد الرحمن بن سليمان ، منهج المدرسة العقلية الحديثة في التفسير ، طبعة مكتبة الرشد بالرياض ، الطبعة الخامسة ب بـ ا هـ. ror- النورسي، الثيخ سعيد، الملقب ببديع الزمان(المتوفى و وسات هـ)، كليات رسائل النور ، الكلمات ، طبعة مكتبة سوزلر للنشروالتوزيع ، القاهرة . به- عرجون، محمد الصادق ، محمد صلي الله عليه وسلم منهج ورسالة، هدية

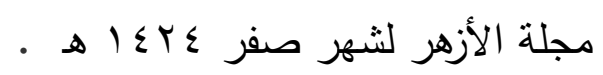

\section{سابعا :- المعاجم وكتب اللغة}

ع - التهانوي ، محمد بن علي بن القاضي محمد حامد بن محمّد صابر الفاروقي الحنفي (المتوفى 101/ اهـ) ، كثاف اصطلاحات الفنون والعلوم ، تقديم وإشراف ومراجعة: د. رفيق العجم ، تحقيق: د. علي دحروج ط ا مكتبة لبنان - بيروت - 1997

هـ- الجرجاني ،علي بن محمد بن علي الزين الثريف (المتوفى: 7 (1/هـ )

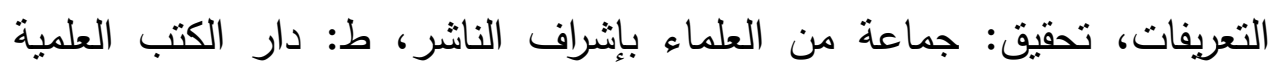

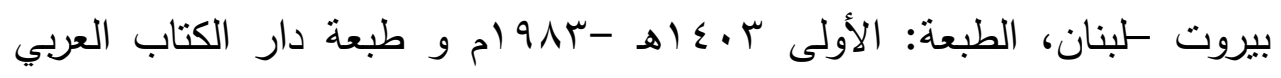
بيروت ، تحقيق/ إبراهيم الإبياري •

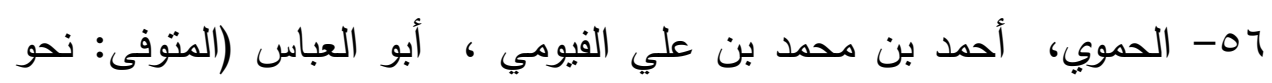
- هـ VVV. . بيروت

V- V الرازي، الإمام محمد بن أبي بكر ، مختار الصحاح، باب النون ، ط مكتبة

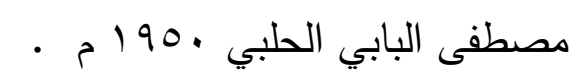
هـ- الزركلي ، خير الدين بن محمود بن محمد بن علي بن فارس، الزركلي الدمشقي (المتوفى: 97 باهـ) الأعلام ، ، الطبعة 10 ، دار العلم للملايين.

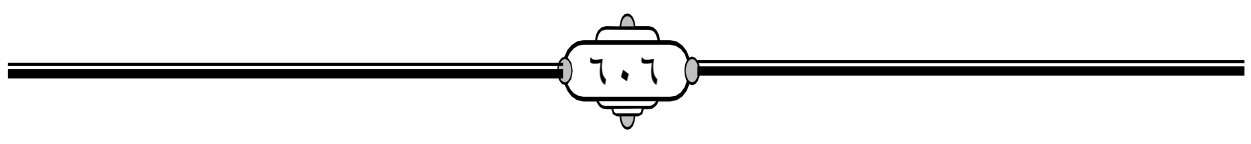


9ه- الزمخشري ، أبو القاسم محمود بن عمرو بن أحمد، جار الله (المتوفى: ^بهـه ، أساس البلاغة تحقيق: محمد باسل عيون السود، الناشر: دار الكتب العلمية، بيروت - لبنان. • 7- العسكري ، أبو هلا الحسن بن عبد الله بن سهل بن سعيد بن يحيى بن مهران (المتوفى هوبه )الفروق اللغوية، تحقيق: محمد إبراهيم سليم، ط: دار العلم والثقافة للنشر والتوزيع، القاهرة - مصر • آ- الفراهيدي، أبو عبد الرحمن الخليل بن أحمد بن عمرو بن تميم البصري (المتوفى: • V Vه) ، العين ، تحقيق: د مهدي المخزومي، د إبراهيم السامرائي ، ط:

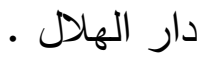
r7- الفيروز آبادي، محمد بن يعقوب ، القاموس المحيط ، ط دار الحديث القاهرة . باج- المناوي ، الثيخ محمد عبد الرعوف (المتوفى اس ·1 هـ)، التوقيف علي مهمات التعاريف تحقيق محمد رضوان الداية ، ط دار الفكر المعاصر ، بيروت

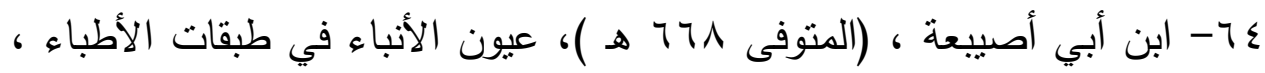
تحقيق نزار رضا ، ط دار مكتبة الحياة ، بيروت. 07- ابن خلدون ، العلامة عبد الرحمن بن محمد بن خلدون الحضرمي(المتوفى

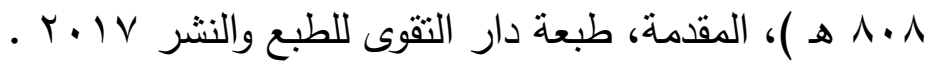
צج- ابن فارس ، أبو الحسين أحمد بن فارس بن زكريا الرازي (المتوفى هوب هـ) معجم مقاييس اللغة ، تحقيق / عبد السلام محمد هارون، طبعة دار الفكر، ط

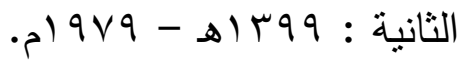

V7 - ابن منظور، محمد بن مكرم بن على، أبو الفضل، جمال الدين الأنصاري الرويفعى (المتوفى: I IVه) لسان العرب، الناشر: دار صادر - بيروت الطبعة:

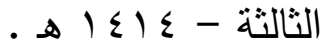

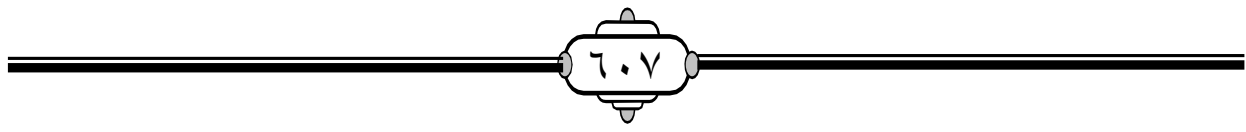


^^- أبو الفرج محمد بن إسحاق بن محمد الوراق البغدادي ، المعروف بابن النديم

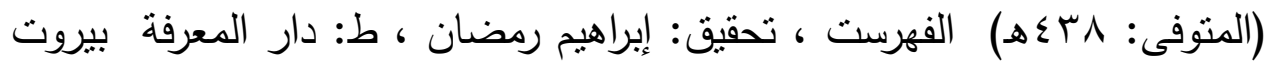
- لبنان

9 - جميل صليبا ، المعجم الفلسفي بالألفاظ العربية والفرنسية والإنجليزية واللاتينية

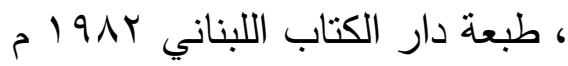
• الكنب المصرية. ا V- عبد الحميد ، أحمد مختار ، معجم اللغة العربية المعاصرة ط عالم الكتب،

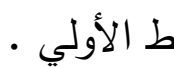
ك والمناظرة ، ط ،المكتبة التجارية الكبرى بمصر ، ط السابعة 1901 ـ rV- عمر رضا كحالة ، معجم المؤلفين ، طبعة مكتبة المثنى ، دار إحياء التراث ، بيروت.

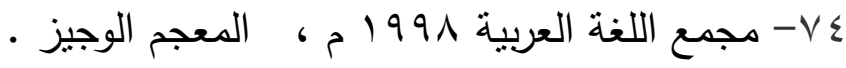
0 - مصطفى، إبراهيم وأخرون ، المعجم الوسيط ، إصدار مجمع اللغة العربية ،

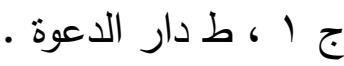

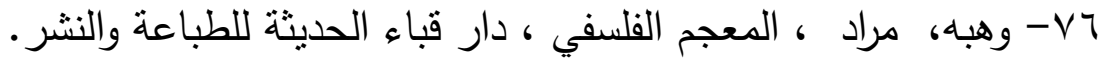
- المرجع ويكيبديا الموسوعة الحرة -VV (2صطفى_السيد_(عالم_فيزياء//https://ar.wikipedia.org/wiki

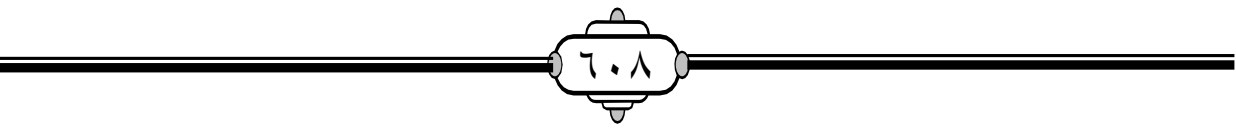

